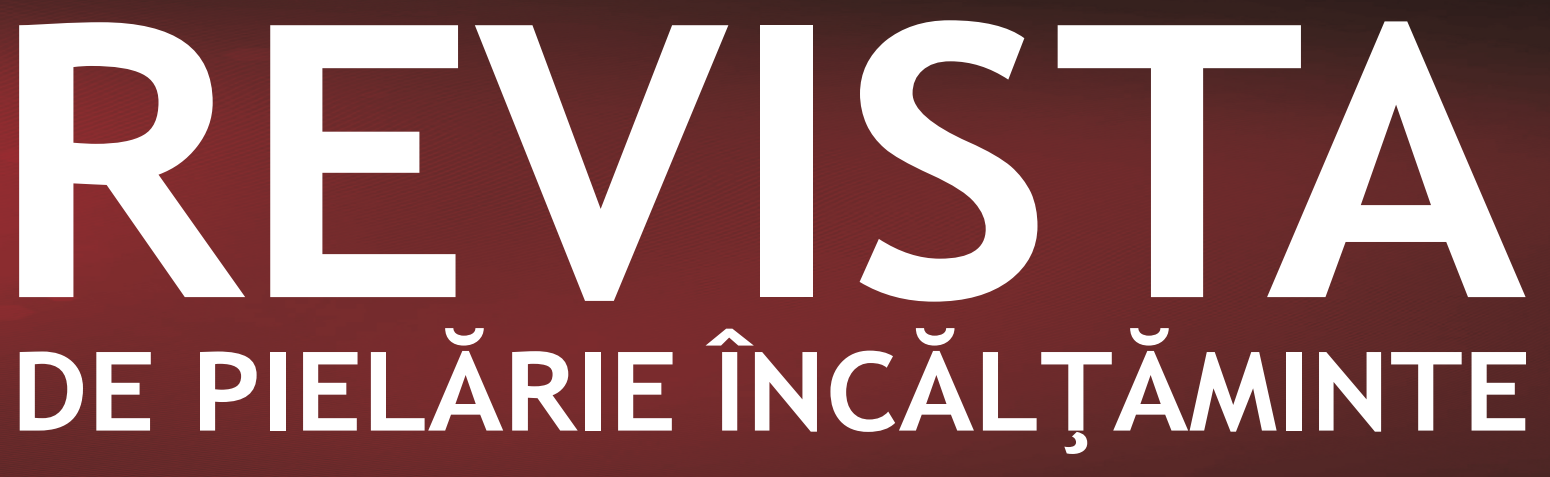

\title{
Leather and Footwear Journal
}

September / Septembrie 2017 Volume / Volumul 17

No / Numărul 3

\section{INCDTP - SUCURSALA INSTITUTUL DE CERCETĂRI PIELĂRIE ÎNCĂLTIMIMINTE}

\section{INCDTP - DIVISION: LEATHER AND FOOTWEAR RESEARCH INSTITUTE}

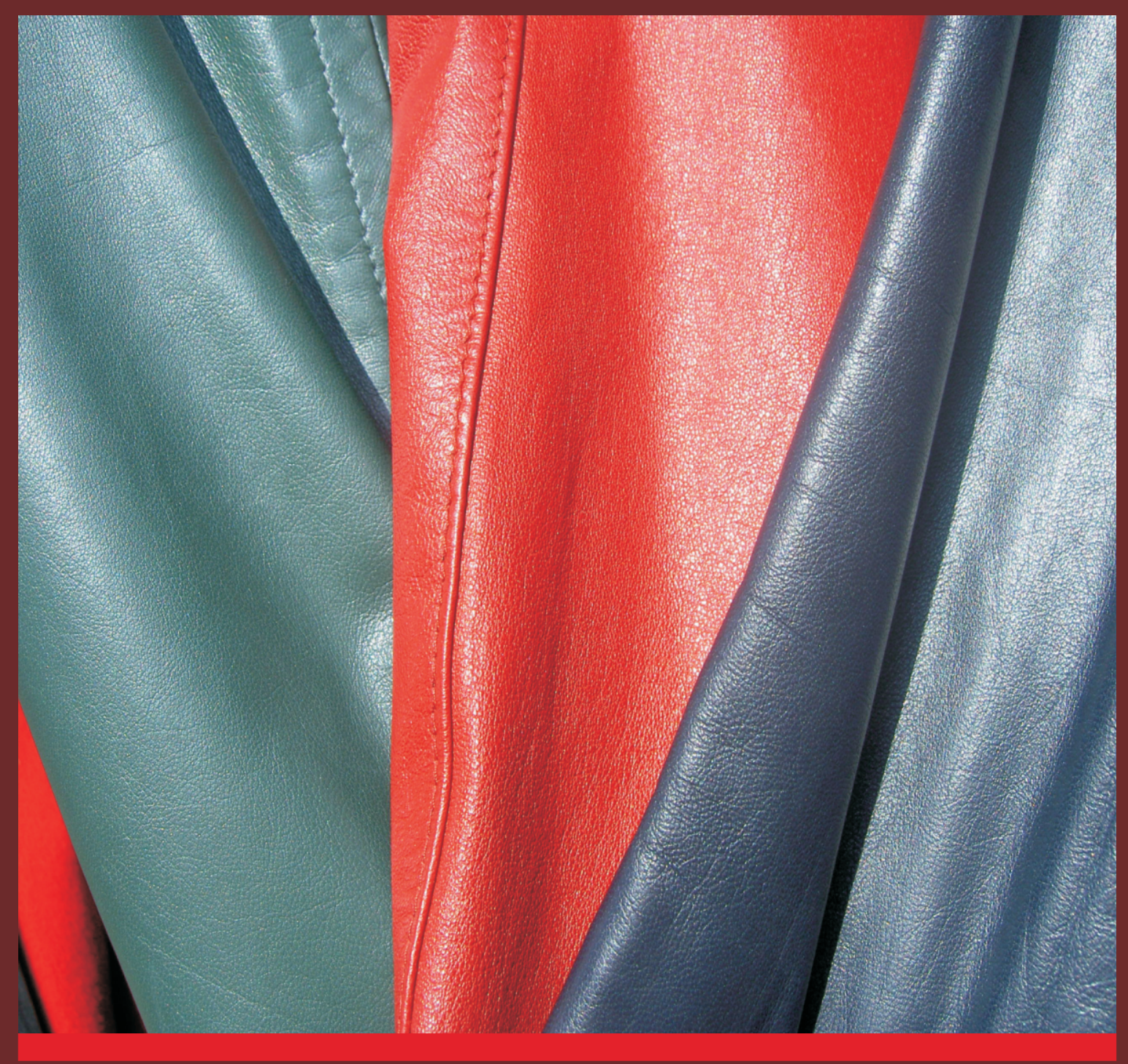




\section{AIMS AND SCOPE}

Revista de Pielarie Incaltaminte / Leather and Footwear Journal (Print ISSN 1583-4433) is published 4 times a year, by Leather and Footwear Research Institute (ICPI) Bucharest, Romania, Division of The National Research and Development Institute for Textiles and Leather (INCDTP), CERTEX Press. Revista de Pielarie Incaltaminte / Leather and Footwear Journal aims to present current science and technology developments as well as initiatives in Romania and South Eastern Europe region. The Journal publishes original research papers of experimental and theoretical nature, followed by scientific, technical, economic and statistic information, reviews of local and foreign conferences, congresses, symposia, with the purpose of stimulating the dissemination of research results.

Revista de Pielarie Incaltaminte / Leather and Footwear Journal focuses particular attention on the key areas of new systems and technologies applied in leather, footwear and rubber goods sectors; biomaterials, collagen-based medical devices, biochemistry of collagen; environment; innovation; leather and parchment cultural heritage; management and marketing, quality control; applications of IT field in these sectors, and other related fields.

\section{OPEN ACCESS STATEMENT}

Revista de Pielarie Incaltaminte / Leather and Footwear Journal is a peer reviewed, open access journal. All articles published open access will be immediately and permanently free for everyone to read, download, copy and distribute, under the provisions of a Creative Commons Attribution (CC BY) which lets others distribute and copy the article, create extracts, abstracts, and other revised versions, adaptations or derivative works of or from an article (such as a translation), include in a collective work (such as an anthology), text or data mine the article, even for commercial purposes, as long as they credit the author(s), do not represent the author as endorsing their adaptation of the article, and do not modify the article in such a way as to damage the author's honor or reputation.

\section{PEER-REVIEW PROCEDURE}

Submission of a manuscript to Revista de Pielarie Incaltaminte implies that the work described has not been published before (except in the form of an abstract or as part of a published lecture, review, or thesis); that it is not under consideration for publication elsewhere; that its publication has been approved by all coauthors, if any.

Submitted manuscripts are single-blind peer-reviewed by two qualified reviewers selected by the Editorial Board. The manuscript will be accepted for publication provided reviews are favorable. In case of diversified opinions of the reviewers, the Editorial board will make the final decision. If the paper is not accepted for publication, the manuscripts and the figures will not normally be returned. The authors will be notified as soon as possible of the result of the paper evaluation (to be published, to be modified, rejected).

\section{JOURNALSPONSORSHIP}

Edited with the sponsorship from the Ministry of Education, Research and Innovation of Romania, National Authority for Scientific Research. We are pleased to acknowledge support from the following: The Confederation of National Associations of Tanners and Dressers of the European CommunityCOTANCE, Belgium; Romanian Leather and Fur Producers Association, APPBR, Romania; SFERA FACTOR, Romania.

\section{COPYRIGHT}

The copyright for all articles published in Revista de Pielarie Incaltaminte / Leather and Footwear Journal shall remain the property of the author(s). The copyright on the layout and final design of the articles published in Revista de Pielarie Incaltaminte / Leather and Footwear Journal belongs to INCDTP - Division: Leather and Footwear Research Institute and cannot be used in other publications.

\section{ABSTRACTING AND INDEXING}

Revista de Pielarie Incaltaminte / Leather and Footwear Journal is acknowledged in Romania by the National University Research Council (CNCSIS) in B+ Category (code 565), and is indexed in Chemical Abstracts Service (CAS) Database, USA, CAB Database (CAB International, UK), Elsevier's Compendex and SCOPUS, CrossRef, EBSCO, CiteFactor, Research
Bible, and listed in Academickeys, Environmental XPRT, MIAR, Electronic Journals Library, Cosmos Impact Factor, Science Library Index and SCIPIO.

INCDTP-ICPI is a member of The Publishers International Linking Association, Inc. (PILA), a nonprofit corporation doing business as Crossref. As a PILA member, we have the right to assign Digital Object Identifiers (DOIs) to journal content. DOIs are persistent links to an object/entity and can be used to cite and link to any article existing online, even if full citation information is not yet available. We strongly recommend that authors cite references using DOIs where possible. For details regarding citation format and examples, please visit the Instructions for Authors section on Revista de Pielarie Incaltaminte / Leather and Footwear Journal's website, http://www.revistapielarieincaltaminte.ro

\section{FEES AND SUBSCRIPTIONS}

Revista de Pielarie Incaltaminte / Leather and Footwear Journal requires article processing charges of 100 EURO per article, for accepted manuscripts, payable by the author to cover the costs associated with publication. There are no submission charges.

Hard copies of journal issues are available for purchase at subscription rates of 160 EURO for companies and 100 EURO for individual subscribers, while the rate for a single issue is 40 EURO. Subscriptions (include mailing costs) can be made at the editorial office, to the following address:

INCDTP - DIVISION: LEATHER AND FOOTWEAR RESEARCH INSTITUTE, 93 Ion Minulescu Street, postal code 031215, sector 3, Bucharest, Romania, Europe.

Both article processing charges and subscription fees are to be paid in the following account:

Account holder: INCDTP - Division: Leather and Footwear Research Institute; Address of the account holder: 93 Ion Minulescu Street, postal code 031215, sector 3, Bucharest, Romania, Europe

IBAN Code: RO25 RNCB 0074029208380005

Bank code: 300413024

Swift bank address: RNCBROBU; Bank: BCR sector 3 (ROMANIAN COMMERCIAL BANK - SECTOR 3); Bank address: 11 Decebal Blvd., BI. S14, sector 3, Bucharest, Romania.

\section{CORRESPONDENCE}

Editor-in-Chief-Dr. Viorica Deselnicu

INCDTP - Division: Leather and Footwear Research Institute (ICPI), 93, Ion Minulescu Street, Bucharest, sector 3, postal code 031215, Romania, Europe; tel./fax: + 402132352 80, e-mail: jlfjournal@gmail.com

CERTEX Publishing House - Bucharest, 16 Lucreţiu Pătrăşcanu St., sector 3; Tel./ Fax: (0040) 21 340.55.15; certex@ns.certex.ro

Website: http://www.revistapielarieincaltaminte.ro Facebook: http://www.facebook.com/LeatherFootwearJournal Title DOI: https://doi.org/10.24264/Ifj 


\section{EDITOR IN CHIEF \\ Dr. Viorica DESELNICU}

Scientific Secretary

INCDTP - Division: Leather and

Footwear Research Institute, Bucharest
EDITOR

Dr. Luminita ALBU

Director

INCDTP - Division: Leather and

Footwear Research Institute, Bucharest
EDITORIAL ASSISTANT

Dana GURAU

\section{EDITORIAL ADVISORY BOARD}

\section{Prof. Dr. Aurel ARDELEAN}

Western University "Vasile Goldis" Arad 94-96 Revolutiei Blvd., 310025, Arad, Romania Member of the Romanian Academy of Medical Sciences, Member of Academy of Science, New York Tel./Fax: +40257280335 e-mail: rectorat@uvvg.ro

\section{Prof. Dr. Altan AFSAR}

Ege University Faculty of Engineering Leather Engineering Department 35100, Bornova, Izmir, Turkey Tel: + 90 232-3884000/2644; Fax: +90 2323425376 e-mail: altan.afsar@ege.edu.tr

\section{Prof. Dr. Viaceslav BARSUKOV}

National University of Technology \& Design

2, Nemyrovych-Danchenko Str., Kiev, Ukraine

Tel./Fax: +380 (44) 290-05-12

e-mail:chemi@mail.vtv.kiev.ua

\section{Assoc. Prof. Dr. Mehmet Mete MUTLU}

Ege University, Faculty of Engineering Leather Engineering Department, 35100 Bornova, Izmir, Turkey Tel.: +90 2323880110 - 2644; Fax: + 902323425376 e-mail: mete.mutlu@ege.edu.tr

\section{Prof. Dr. Todorka Gancheva VLADKOVA}

University of Chemical Technology and Metallurgy, Bld. Kliment Ohridsky 8, Sofia, 1756, Bulgaria e-mail: tgv@uctm.edu

\section{Prof. Dr. Margareta FLORESCU}

The Bucharest Academy of Economic Studies 6 Piata Romana, 010374, Bucharest, Romania Tel.: +40 21319 1900; + 40213191901

Fax: +40 213191899

e-mail: icefaceus@yahoo.com

\section{Assoc. Prof. Dr. Zenovia MOLDOVAN}

University of Bucharest 90-92 Şos. Panduri, 050663, sector 5, Bucharest, Romania Tel.: +40 21 4103178/125 e-mail: z_moldovan@yahoo.com

\section{Prof. Dr. Wuyong CHEN}

National Engineering Laboratory for Clean Technology of Leather Manufacture, Sichuan University, Chengdu 610065, Sichuan, P. R. China Tel: +86-(0)28-85404462; +86-28-85405840 Fax: +86-28-85405237

e-mail:wuyong.chen@163.com

\section{Dr. Ding ZHIWEN}

China Leather \& Footwear Industry Research Institute 18 Jiangtaixi Road, Chaoyang District, Beijing, P. R. China, 100015 Tel: +86-10-13701315570 e-mail: ding-zhiwen@263.net

Prof. Dr. Aurelia MEGHEA

University "Politehnica" of Bucharest

1-7 Polizu, sector 1, 011061, Bucharest, Romania Tel.: +400212129952

e-mail:a_meghea@chim.upb.ro

\section{Assoc. Prof. Dr. Sergiu Stelian MAIER}

"Gh. Asachi" Technical University of lasi 67 Dimitrie Mangeron Blvd., laşi, Romania Tel.: +40 2322123 22; Fax: +40 232-21 1667 e-mail:smaier@ch.tuiasi.ro

\section{Dipl. Eng. Mariana VOICU}

Ministry of Economy, Trade and Tourism 152 Calea Victoriei, sector 1, 010096, Bucharest, Romania Tel. +4021/2025158; Fax: +4021/2025159 e-mail: Mariana_Voicu@minind.ro

\section{Dipl. Eng. Dorel ACSINTE}

Director of S.C PIELOREX S.A.

President of Romanian Leather and Fur Producers Association, APPBR

$33 \mathrm{~A}$, Prelungirea Sos. Giurgiului, Jilava, Ilfov, Romania Tel. + 4031425 5556; Fax + 40214571018

e-mail: pielorexsa@yahoo.com, appb.ro@gmail.com

\section{Prof. Dr. Aura MIHAI}

"Gh. Asachi" Technical University of lasi 67 Dimitrie Mangeron Blvd., Iaşi, Romania Tel.: +40 2322123 22; Fax: +40 232-21 1667 e-mail: amihai@tex.tuiasi.ro

Assoc. Prof. Dr. Dana Corina DESELNICU University "Politehnica" of Bucharest 1-7 Polizu, sector 1, 011061, Bucharest, Romania Tel.: +40 0212129952 e-mail: dana.deselnicu@upb.ro 
ISSN: 1583-4433

Volume 17, No. 3, September 2017

https://doi.org/10.24264/Ifj.17.3

\section{CONTENTS}

Rishi DWIVEDI

Shankar CHAKRABORTY

Jinming LIU

Kun HU

Hui SU

Bo XU

Jiuping $X U$

Jin ZHOU

Md. Abu SAYID MIA

Md. NUR-E-ALAM

M. Kamal UDDIN

Maria Daniela STELESCU

Elena MĂNĂILĂ

Maria SÖNMEZ

Mihaela NITUICĂ

Victor JOHN SUNDAR

Chellappa

MURALIDHARAN
Strategic Decision Making for a Footwear Industry Using Activity Based Costing and Value Chain Models

Classification of Diabetic Feet in terms of Risk of Ulceration

Court Shoe Production Line: Improve Process Cycle Efficiency by Using Lean Tools

Characteristics of Polymer Composites Based on Natural Rubber

A Study on Water Vapour Permeability with Increased Functional Properties of Upper Leathers

Pressure Distribution Patterns and Shapes of foot under Long-Term Loads

Footwear Protection against Fungi Using Thyme Essential Oil

\section{CUPRINS}

Luarea unor decizii strategice pentru industria de încălţăminte utilizând metoda stabilirii costului pe baza activităţii şi modelele lanţurilor valorice

Clasificarea piciorului diabetic în funcţie de riscul de ulceraţie

Linie de producţie a pantofilor clasici: îmbunătăţirea eficienţe procesului prin utilizarea instrumentelor suple

Caracteristicile unor compozite polimerice pe bază de cauciuc natura

Studiu privind efectu permeabilităţii la vapori de apă asupra îmbunătăţirii proprietăţilor funcţionale ale pieilor pentru feţe încălţăminte

Tiparele de distribuţie a presiunii şi forma piciorulu sub sarcini pe termen lung

Protejarea încălţăminte împotriva fungilor utilizând uleiul esenţial de cimbru

\section{SOMMAIRE}

Décision stratégique pou l'industrie de la chaussure à l'aide du calcul des coûts par activité et du chaîne de valeur

Classification des pieds diabétiques selon le risque d'ulcération

Ligne de production des chaussures classiques: améliorer l'efficacité du procédé en utilisant les outils de gestion allégée

Les caractéristiques des compositions polymériques en caoutchouc naturel

Une étude sur la permeabilité à la vapeur d'eau pour augmenter les propriétés fonctionnelles des tiges cuir

Les modèles de distribution de pression et les formes du pied sous des pressions à long terme

La protection des chaussures contre les champignons en utilisant l'huile essentielle de thym 


\title{
STRATEGIC DECISION MAKING FOR A FOOTWEAR INDUSTRY USING ACTIVITY BASED COSTING AND VALUE CHAIN MODELS
}

\author{
Rishi DWIVEDI ${ }^{1}$, Shankar CHAKRABORTY2* \\ ${ }^{1}$ Center for Business Administration, Central University of Jharkhand, Ranchi, India \\ ${ }^{2}$ Department of Production Engineering, Jadavpur University, Kolkata, India
}

STRATEGIC DECISION MAKING FOR A FOOTWEAR INDUSTRY USING ACTIVITY BASED COSTING AND VALUE CHAIN MODELS ABSTRACT. Majority of the enterprises in modern day world are facing speedy transformation in their business dynamics. Organizational challenges have been deepened by the deregulation, in tandem with the escalating worldwide competition and diminution in product life cycles resulting from scientific modernization. Hence, with a view to be competitive under these vibrant conditions, it is important to comprehend how a business functions, how costs are incurred and how they can be efficiently managed. Activity based costing (ABC) model is a new cost accounting approach developed to overcome limitations of the traditional volume-based cost accounting methods and enhance its usefulness in strategic decision making. This paper presents the development and application of an $A B C$ model to cost the entire range of products of an Indian footwear manufacturing industry in order to enhance its competitiveness. Although, there is sufficient published research papers associated with implementation of $A B C$ model in manufacturing sector, none of them has adopted $A B C$ technique in the context of footwear manufacturing. Furthermore, a combined approach employing $A B C$ and value chain models is proposed for the first time for the said footwear industry to demonstrate how it can be implemented in a complementary way to formulate a superior strategy. KEY WORDS: activity based costing; value chain analysis; footwear industry; activity; strategy

\section{LUAREA UNOR DECIZII STRATEGICE PENTRU INDUSTRIA DE ÎNCĂLȚĂMINTE UTILIZÂND METODA STABILIRII COSTULUI PE BAZA ACTIVITĂṬII ȘI MODELELE LANȚURILOR VALORICE}

REZUMAT. Majoritatea întreprinderilor din lumea modernă se confruntă cu o transformare rapidă a dinamicii afacerilor. Provocările organizaționale au fost intensificate de dereglementare, în paralel cu creșterea concurenței la nivel mondial și diminuarea ciclului de viață al produselor rezultate în urma modernizării științifice. Prin urmare, pentru a fi competitiv în aceste condiții dinamice, este important să se înțeleagă cum funcționează o afacere, cum sunt suportate costurile și cum pot fi gestionate eficient. Modelul de stabilire a costurilor pe baza activității $(\mathrm{ABC})$ reprezintă o nouă abordare a contabilizării costurilor, dezvoltată pentru a depăși limitele metodelor tradiționale de contabilizare a costurilor pe baza volumului și pentru a spori utilitatea acesteia în procesul decizional strategic. Această lucrare prezintă dezvoltarea și aplicarea unui model $A B C$ pentru a contabiliza costurile unei întregi game de produse din industria de fabricare a încălțămintei din India, pentru a spori competitivitatea acesteia. Deși există suficiente studii de cercetare publicate în legătură cu implementarea modelului $A B C$ în sectorul de producție, niciunul dintre acestea nu a adoptat tehnica $A B C$ în contextul producției de încălțăminte. În plus, se propune pentru prima dată o abordare combinată care utilizează modelele $A B C$ și lanțul valoric pentru industria încălțămintei, pentru a demonstra modul în care acestea pot fi implementate într-un mod complementar pentru a formula o strategie superioară.

CUVINTE CHEIE: stabilirea costurilor pe baza activității; analiza lanțului valoric; industria încălțămintei; activitate; strategie

DÉCISION STRATÉGIQUE POUR L'INDUSTRIE DE LA CHAUSSURE À L'AIDE DU CALCUL DES COÛTS PAR ACTIVITÉ ET DU CHAîNE DE VALEUR RÉSUMÉ. La majorité des entreprises du monde moderne sont confrontées à une transformation rapide de leur dynamique commerciale. Les défis organisationnels ont été approfondis par la déréglementation, parallèlement à l'escalade de la concurrence mondiale et à la diminution des cycles de vie des produits résultant de la modernisation scientifique. Par conséquent, en vue d'être compétitif dans ces conditions dynamiques, il est important de comprendre comment fonctionne une entreprise, comment les coûts sont engagés et comment ils peuvent être gérés efficacement. Le modèle de calcul des coûts à base d'activité $(A B C)$ est une nouvelle méthode de comptabilité développée pour surmonter les limites des méthodes comptables traditionnelles basées sur le volume et pour améliorer son utilité dans la prise de décision stratégique. Cet article présente le développement et l'application d'un modèle ABC pour calculer les coûts de toute la gamme des produits de l'industrie indienne de la chaussure afin de renforcer sa compétitivité. Bien qu'il existe suffisamment de documents de recherche publiés associés à la mise en œuvre du modèle $A B C$ dans le secteur manufacturier, aucun d'entre eux n'a adopté la technique $A B C$ dans le contexte de la fabrication de chaussures. De plus, une approche combinée utilisant les modèles $A B C$ et les chaînes de valeur est proposée pour la première fois pour l'industrie de la chaussure, afin de montrer comment on peut les mettre en œuvre de manière complémentaire pour formuler une stratégie supérieure.

MOTS CLÉS : calcul des coûts par activité ; analyse de la chaîne de valeur ; industrie de la chaussure ; activité ; stratégie

\section{INTRODUCTION}

The leather and footwear sector has a prominent role to play in overall progress of the Indian economy owing to its huge social and economic contribution. It is providing jobs to about 3 million people, generally from the weaker sections of the society, based on a report published in The Hindu in 2017.
With knowledge and technology of footwear manufacturing progressing year after year, the Indian footwear industry is inscribing its dominance and capability in the international markets. According to information derived from the website of India Brand Equity Foundation in 2016, India is the second largest global producer of footwear and leather garments, accounting * Correspondence to: Shankar CHAKRABORTY, Department of Production Engineering, Jadavpur University, Kolkata, India, e-mail:
s_chakraborty00@yahoo.co.in 
for $12.9 \%$ of global production of hides/skins. It is observed that a number of new trends have emerged in the recent past in the Indian footwear industry which indicate the future growth of this sector. For example, numerous organizations in the market are providing an assortment of stylish eco-friendly footwear to ensure that the customers do not forfeit on comfort or style, while choosing green shoes. In the same way, progressively more people are now opting for customized or exclusive footwear, which is creating more prospects for footwear designers. Moreover, younger generation, being more style conscious, prefers ethnic footwear to give a touch of Indian glamour to their western attire. Numerous customers in India now spend as much on footwear as on clothing and change their shoes/slippers/sandals for assorted events, which in turn, helps to expand footwear range from formals, casuals and homewear to weddings, monsoons, clubwear, sportswear, adventure, beachwear and lounge wear. According to the India Retail Report published in 2016, these trends have assisted the footwear industry to grow at almost $18 \%$, and it is expected that India's total retail footwear market would cross Rs. 540 billion by 2017 from its current worth of Rs. 335.92 billion. Besides, growing disposable incomes, profusion of raw materials, advent of new-fangled and superior designs to customers, burgeoning retail opportunities and vibrant export market have also been the growth drivers of the footwear sector in India. In addition, the footwear sector is not expected to face impact of any slowdown in the Indian economy because of a number of external stimulators that include more women joining the workforce, an increasing desire to look good and rise in customers' aspiration levels.

Indian footwear industry has a few national and multinational enterprises present in the organized segment, and a hefty unorganized section characterized by slipper/ sandal manufactures is dominated by small regional organizations. At present, there is a ruthless competition among various footwear manufacturing organizations operating in the Indian market. Growing competition is forcing the organizations to invigorate their footwear product collection at a faster rate than before. Footwear manufacturers are also witnessing a rise in the retailing of shoes/slippers/sandals with the upsurge of e-commerce and the emergent trend of online shopping. Till date, majority of the Indian footwear manufacturers are engaged in practicing traditional cost accounting systems, which often fail to provide precise and accurate cost information as required in streamlining the strategic decisions in order to augment quality of decisions. This limitation of traditional cost accounting systems arises owing to their dependence on arbitrary rather than cause and effect allocation of overhead costs. Production volume-related measures are utilized in the traditional cost accounting systems to allocate overhead costs to products, although several products do not require indirect resources, i.e. overhead costs proportionately to the quantity of products manufactured. Thus, the traditional costing systems distort product cost as many types of overhead costs are driven through non-production volume-related cost drivers, such as size, dimension and complexity. The activity based costing $(A B C)$ model is designed as a modern cost accounting tool to trounce the limitations of traditional costing systems. It is developed to gratify the demands of modern day enterprises which are characterized by a wide range and complexity of products and services, high overhead costs in comparison to direct labor cost and a surplus of cost data. Contrasting to the traditional cost accounting systems, ABC model acknowledges the fact that not all activities (and thus resource consumption rates) are proportional to the number of units produced [1]. On the other hand, value chain analysis (VCA) is a technique employed to evaluate internal company activities. Its objective is to identify activities that are basically significant to organizational success, and are the foundation of cost or differentiation advantage. Moreover, VCA method also intends to recognize those activities of an enterprise which can be improved to provide a competitive edge. Therefore, in this paper, an $A B C$ model is developed for a footwear manufacturing industry in the state of West Bengal in India to cost its various products. The derived results from the application of $A B C$ model in the said enterprise will help its managers in improving the organizational performance, productivity and profitability. The comprehensive application 
procedure of the developed $A B C$ model is also discussed. An integrated ABC-VCA model is then proposed for the said enterprise to comprehend the reasons for ineffectiveness in the chain and recognize potential leverage points for enhancing the performance of the chain.

\section{REVIEW OF THE LITERATURE}

Ridderstolpe et al. [2] presented the application of a model for process analysis and $A B C$ method at a Heart Center in Sweden as a technique for administrative cost information, strategic decision making, quality improvement and cost reduction. Dickinson and Lere [3] demonstrated the ways how $A B C$ technique could help in managing the marketing functions of an organization. Hughes [4] exhibited the potential of $A B C$ model in improving the competitive performance of SMEs, mainly in the UK clothing and textile industry. Banker et al. [5] examined the impact of $A B C$ model on adoption of world class manufacturing practices and plant performance. Stelling et al. [6] employed an $A B C$ model to present a methodology for estimating the cost of a process, crucial to its evaluation. Carli and Canavari [7] proposed a model for a new information system for agribusiness management that would support direct costing and $\mathrm{ABC}$ methods. Mashayekhi et al. [8] evaluated the viability of implementing activity based budgeting in Sharif University of Technology. Dwivedi and Chakraborty [9] implemented $A B C$ model in a pulse mill of India to cost its entire range of products. Maiga [10] assessed the association between $A B C$ model adoption and four manufacturing plant performance measures (cycle time improvement, quality improvement, cost improvement and profitability), and investigated selection bias and endogenous nature of their relationship. Dwivedi and Chakraborty [11] applied an ABC model in an engineering department of an autonomous university in India. Shama et al. [12] presented an approach to integrate life cycle assessment and activity based life cycle costing methodology with a view to recognize the improvement opportunities for sustainable products. Tsai et al. [13] proposed a programming decision model based on $A B C$ management system for the electrical and electronic industry that aimed at sustainable development and encompassed various advantages generated through the appraisal process. Dwivedi and Chakraborty [14] implemented an $A B C$ model in a raw material handling department of an Indian steel plant to demonstrate its efficiency in providing accurate and precise cost information in a more management friendly manner.

Taylor [15] developed an innovative methodology to apply lean value chain improvement technique to a complete supply chain for a food product. Souza and D'Agosto [16] utilized a VCA method to verify whether it could be possible to distribute financial benefits along the scrap tire reverse logistics chain considering co-processing in the cement industries as the destination. Olson [17] applied the concept of green innovation value chain framework to analyze the photovoltaic solar power chain. Thomas [18] discussed about the recent tourism value chains to show that the impact of tourism would greatly depend upon the chosen poverty threshold. Tomić and Andrijašević [19] assessed the possibilities of integrated use of target costing, $A B C$ and Kaizen methodologies in the internal value chain as the central link of the entire chain. Yan and Wang [20] quantitatively analyzed the value flow of iron resources in China while employing the material flow and VCA methods. Wang [21] provided a comprehensive outline of the value chain of bio-coal business in Finland, defined the proper business models of bio-coal business and investigated the interrelationships between value chain activities. Hamilton-Hart and Stringer [22] presented a framework for fishery sector analysis based on the works conducted on global value chains and global production networks.

It follows from the foregoing literature review that $A B C$ model has been successfully applied in manufacturing as well as service sectors because of its ability to evaluate cost of a product or service at an assortment of activity levels in order to provide more precise cost information. But, there is no published research paper associated with implementation of $A B C$ model in any footwear industry. Hence, for the first time, this paper explores the applicability and potentiality of an $A B C$ model in footwear sector for providing the decision makers with pragmatic and strategic outlook of the cost related to various activities of the enterprise that are critical in efficient planning, controlling and decision making. Additionally, an 
integrated ABC-VCA model is developed to exploit the complementary synergies of both $A B C$ and VCA models.

\section{ABC MODEL}

Existing business environment has shown that the information derived through application of the traditional costing systems is not sufficient for business management. Traditional costing systems are not only incapable to provide the essential structure for measuring cost precisely, but they are also incompetent to empower managers with sufficient information required for organizing the enterprise's everyday activities successfully and proficiently. The key objection to traditional costing systems is the allotment of overhead costs based on volume-based drivers. The $A B C$ model is a contemporary management accounting tool which helps managers of the organizations to evaluate internal process of the enterprise, estimate accurate product and customer profitability, institute superior performance measures, appraise novel investment opportunities, set better budget allotment, initiate cost minimization procedure and establish an efficient resource requirement plan. Principally, $A B C$ is a two stage method for assigning overhead costs to product units based on cost drivers at different levels of activity. In the first step, resource costs are allocated to cost pools that correspond to various categories of activities performed by the organization. Cost allocated to different activity pools are subsequently assigned to the products that benefit from or create the demand for the activities.

\section{ABC Model Development and Implementation in a Footwear Industry}

The accounting system of a slipper manufacturing industry is considered here for development and subsequent implementation of $A B C$ model. The identity of this enterprise is not disclosed here for confidentiality and anonymity reason and hereafter, it is referred to as BNL Limited. It is a private limited company, situated in the state of West Bengal in India and produces 17 different types of slipper to meet varied demands of the customers. It is observed that BNL Limited sells those 17 slipper variants, named hereafter as $A B, A E, A F, A T, B O, C A, C O$, $C L, D Y, K E, L D, N C, P H, S Y, T O, T S$ and $Y S$ in the local market apart from supplying them to some neighboring states, such as Odisha, Assam, Bihar, Uttar Pradesh and Jharkhand. The BNL Limited has 225 full time employees, which comprise laborers, supervisors, technical persons and administrative staffs. All the pertinent data necessary for implementation of $A B C$ model in the said organization are accumulated for the month of May of the financial year 2015-2016. Each and every activity required to manufacture those 17 footwear variants in BNL Limited are critically analyzed and grouped into 17 homogeneous activity cost pools. It is observed that batching (sole), mixing of raw materials, sheeting (sole), sole pressing, sole cutting, drilling, cleaning, batching (strap), kneeding, accelerator mixing, sheeting (strap), strap pressing, strap cutting, strap fitting, inspection and quality control, and administration are the 16 activity pools required for production of all categories of slipper. Additionally, printing is observed as an activity pool that is required besides the abovementioned activities for production of AF, AT, BO, $C L, D Y, S Y, T S$ and $Y S$ kinds of slipper. The detailed production process of different categories of slipper in BNL Limited is exhibited in Figure 1.

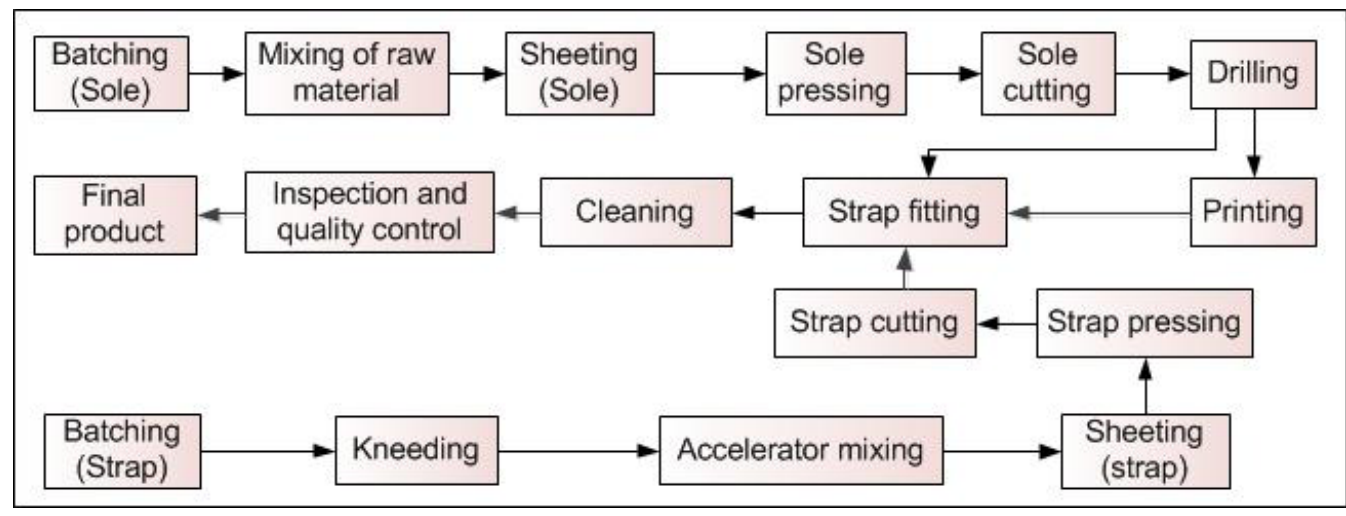

Figure 1. Detailed production process in BNL Limited 
Activity pools of batching (sole) and batching (strap) include the total expenditure incurred in different activities related to arrangement of all the relevant raw materials required for producing soles and straps of a particular slipper at the shop floor respectively. It is observed that the batched raw materials for sole manufacture are mixed utilizing different equipments, viz. intermix and rollers to prepare a lump. On the other hand, kneeder and rollers are employed to mix the batched raw materials of strap manufacturing into 'falli'. Therefore, the total cost related to running of intermix and rollers is allocated to activity pool of mixing of raw material, whereas, activity pool of kneeding comprises the total expense incurred on operation of kneeder and rollers. Furthermore, accelerator is added to 'falli' to enhance its softness, so the total cost associated with accelerator addition process is accumulated into the activity pool of accelerator mixing. Moreover, the total costs related to each and every activity needed for producing smooth sole and strap plies with a desired thickness are put into the activity pools of sheeting (sole) and sheeting (strap) respectively. Sole pressing or strap pressing machines are employed to press different sole or strap plies together into a single sole or strap according to design requirements and therefore, the total expense incurred on all activities connected to operation of sole pressing or strap pressing machines is attached to activity pool of sole pressing or strap pressing. Similarly, the total costs associated with those activities as directly related to cutting of soles and straps are congregated in the sole cutting and strap cutting cost pools respectively. Further, the total payout given to third party as well as the related salary expenditure incurred for making holes on soles of various slipper products is put into activity pool of drilling. It is noticed that screen printers are often utilized to print different designs on soles of various products, so the total expense incurred in all the activities linked to those screen printers is placed into the activity pool of printing. The activity pool of cleaning contains the total cost related to those activities required during removal of any dust and edge from the finally produced slippers. Overheads associated with the inspection process in quality assurance of the slipper products are separated into the inspection and quality control cost pool.
The activity pool of strap fitting consists of total expenditure incurred on all those activities as carried out in fitting straps into the holes of slipper soles. Administration cost pool includes the compensation and related benefits of those employees who accomplish the administrative/ clerical activities of BNL Limited and other non-salary administrative expenses incurred to support production of the footwear items. Now, it is estimated that the total costs related to 17 activity cost pools of batching (sole), mixing of raw material, sheeting (sole), sole pressing, sole cutting, drilling, printing, strap fitting, cleaning, inspection and quality control, batching (strap), kneeding, accelerator mixing, sheeting (strap), strap pressing, strap cutting and administration are Rs. 41441.29, Rs. 536114.33, Rs. 516526.79, Rs. 1232830.51 , Rs. 352664.13 , Rs. 179828.60 , Rs. 328456.13 , Rs. 1115296.16, Rs. 93549.33, Rs. 107363.09, Rs. 27627.53, Rs. 179379.24, Rs. 248121.08 , Rs. 263984.94, Rs. 424577.98, Rs. 420981.60 and Rs. 377722.91 respectively. A range of cost drivers depicting the cause and effect relationships is chosen to allocate costs related to 17 activity cost pools to 17 identified cost objects, i.e. $A B, A E, A F, A T, B O, C A, C O, C L$, DY, KE, LD, NC, PH, SY, TO, TS and YS. Based on the proportionate number of related machine hours required at unit level of production, the total costs allocated to mixing of raw material, sheeting (sole), sole pressing, kneeding, accelerator mixing, sheeting (strap) and strap pressing are apportioned among the cost objects. The total costs associated with activity pools of batching (sole), sole cutting, drilling, strap fitting, cleaning, inspection and quality control, batching (strap), strap cutting and administration are allocated to different cost objects, i.e. $A B, A E, A F$, $A T, B O, C A, C O, C L, D Y, K E, L D, N C, P H, S Y, T O, T S$ and $Y S$ according to the proportionate utilization of those nine activities during production of each type of slipper in BNL Limited. Besides, printing is the process that is only utilized for producing $A F, A T, B O, C L, D Y, S Y, T S$ and YS categories of slipper. Thus, the total cost assigned to activity pool of printing is proportionately allotted to cost objects of $A F, A T, B O, C L, D Y, S Y, T S$ and YS based on the total printing time required for production of those eight categories of slipper. So, it is calculated that the costs allocated to $A B$, $A E, A F, A T, B O, C A, C O, C L$, DY, KE, LD, NC, SY, TO, 
$\mathrm{PH}, \mathrm{TS}$ and $\mathrm{YS}$ in BNL Limited are Rs. 865793.84, Rs. 113436.12 , Rs. 167694.75 , Rs. 111528.73, Rs. 54253.86, Rs. 495528.39, Rs. 61244.90, Rs. 344911.91, Rs. 901840.18, Rs. 117399.48, Rs. 122360.19, Rs. 151783.91, Rs. 54762.77, Rs. 261136.39, Rs. 1010153.30 , Rs. 1454459.67 and Rs. 158177.25 respectively. These are the overhead costs associated with the total volume of monthly production of each type of slipper. So, the overhead cost per pair for individual category of slipper is estimated after dividing this total overhead cost by the total pairs of each type of slipper produced during the concerned month. The total cost per pair for each type of slipper is then estimated by summing up the corresponding overhead cost, raw material cost and packaging material cost. Table 1 shows the detailed calculation of total cost per pair for each type of slipper in BNL Limited, as calculated using $A B C$ model.

Table 1: Total cost/pair in BNL Limited estimated using ABC model

\begin{tabular}{ccccc}
\hline Variant & $\begin{array}{c}\text { Total overhead cost/ } \\
\text { pair (Rs.) }\end{array}$ & $\begin{array}{c}\text { Raw material cost/ } \\
\text { pair (Rs.) }\end{array}$ & $\begin{array}{c}\text { Packaging material cost/ } \\
\text { pair (Rs.) }\end{array}$ & Total cost/pair (Rs.) \\
\hline AB & 7.21 & 46.55 & 9.45 & 63.21 \\
AE & 16.44 & 42.58 & 7.85 & 66.87 \\
AF & 8.15 & 64.25 & 19.45 & 91.85 \\
AT & 10.76 & 34.64 & 5.02 & 50.42 \\
BO & 16.44 & 71.25 & 21.56 & 109.25 \\
CA & 6.45 & 48.29 & 11.56 & 66.30 \\
CO & 20.83 & 47.58 & 13.65 & 82.06 \\
CL & 6.45 & 68.05 & 24.45 & 98.95 \\
DY & 8.09 & 43.75 & 14.5 & 66.34 \\
KE & 15.17 & 38.54 & 9.57 & 63.28 \\
LD & 7.87 & 48.85 & 16.85 & 73.57 \\
NC & 10.50 & 46.52 & 16.56 & 73.58 \\
SY & 6.71 & 67.65 & 25.85 & 100.21 \\
TO & 4.79 & 48.95 & 18.43 & 72.17 \\
PH & 6.86 & 46.78 & 14.85 & 68.49 \\
TS & 7.89 & 43.95 & 11.69 & 63.53 \\
YS & 11.12 & 69.45 & 25.54 & 106.11 \\
\hline
\end{tabular}

\section{Comparison of ABC Model with Traditional Costing System}

The BNL Limited is currently utilizing the traditional costing system for management accounting and financial reporting. The number of slipper pairs produced is employed as a single cost driver to allocate the total overhead cost in the traditional costing system, instead of multiple cost drivers as applied in ABC model. Apart from that, the direct costs related to raw material and packaging material are calculated similarly as in ABC model. Table 2 shows the detailed calculation of cost/pair for each type of slipper in BNL Limited, as estimated using the traditional costing system. Table 3 compares the total cost per pair of slipper and profitability per pair of slipper for BNL Limited as estimated employing both the costing models.

It can be concluded from Table 3 that the traditional costing system distorts the cost of five types of slipper, i.e. $A E, A T, B O, C O$ and $K E$ considerably. For all these categories of slipper, cost/pair is overestimated by the traditional costing system. It is also observed that both the costing models do not estimate the same total cost for any of the slipper variants. These variations in total cost estimation and subsequently profitability assessment are attributed to the way how overhead costs are allocated in $A B C$ model and traditional costing system respectively. The results elicited from the adopted $A B C$ model provides management of the said organization with more accurate and precise cost information, which assists the administration to formulate a realistic budget, identify the inefficiencies, set the unit price of each product produced, devise better product mix and improve the organization's competitiveness. Therefore, the management of this footwear manufacturing industry should start taking various strategic decisions on the basis of the cost information derived from $A B C$ model in order to avoid commercial and operational failure. 
Table 2: Total cost/pair of slipper calculated using traditional costing system

\begin{tabular}{ccccc}
\hline Variant & $\begin{array}{c}\text { Raw material cost/ } \\
\text { pair (Rs.) }\end{array}$ & $\begin{array}{c}\text { Packaging material cost/ } \\
\text { pair (Rs.) }\end{array}$ & $\begin{array}{c}\text { Total overhead cost/ } \\
\text { pair (Rs.) }\end{array}$ & Total cost/pair (Rs.) \\
\hline AB & 46.55 & 9.45 & 7.51 & 63.51 \\
AE & 42.58 & 7.85 & 9.34 & 59.77 \\
AF & 64.25 & 19.45 & 6.26 & 89.96 \\
AT & 34.64 & 5.02 & 6.22 & 45.88 \\
BO & 71.25 & 21.56 & 9.77 & 102.58 \\
CA & 48.29 & 11.56 & 7.55 & 67.40 \\
CO & 47.58 & 13.65 & 10.96 & 72.19 \\
CL & 68.05 & 24.45 & 7.24 & 99.74 \\
DY & 43.75 & 14.5 & 7.52 & 65.77 \\
KE & 38.54 & 9.57 & 8.33 & 56.44 \\
LD & 48.85 & 16.85 & 8.30 & 74.00 \\
NC & 46.52 & 16.56 & 8.92 & 72.00 \\
SY & 67.65 & 25.85 & 7.90 & 101.40 \\
TO & 48.95 & 18.43 & 7.10 & 74.48 \\
PH & 46.78 & 14.85 & 7.44 & 69.07 \\
TS & 43.95 & 11.69 & 7.70 & 63.34 \\
YS & 69.45 & 25.54 & 9.07 & 104.06 \\
\hline
\end{tabular}

The Pareto analysis on the performance of slipper variants based on total profitability contribution as estimated using $A B C$ model is shown in Figure 2. It is noticed that TS, PH, DY, CL, $A B$ and $C A$ are the slipper groups which add most with respect to total profitability contribution. Hence, special care needs to be provided for strategy formulation of those six products as they are vital for long term success of the said organization.

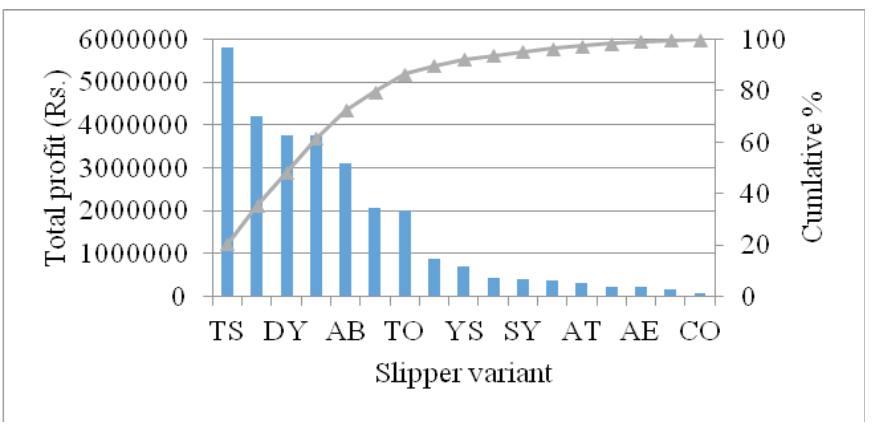

Figure 2. Pareto analysis on total profitability contribution

Table 3: Comparison of cost/pair and profitability/pair of slipper

\begin{tabular}{cccccc}
\hline & & \multicolumn{2}{c}{ ABC model } & Traditional costing system \\
\cline { 3 - 5 } Variant & Price/pair (Rs.) & $\begin{array}{c}\text { Total cost/pair } \\
\text { (Rs.) }\end{array}$ & Profit/pair (Rs.) & $\begin{array}{c}\text { Total cost/pair } \\
\text { (Rs.) }\end{array}$ & Profit/pair (Rs.) \\
\hline AB & & 63.21 & 25.79 & 63.51 & 25.49 \\
AE & 89 & 66.87 & 32.13 & 59.77 & 39.23 \\
AF & 99 & 91.85 & 43.15 & 89.96 & 45.04 \\
AT & 135 & 50.42 & 28.58 & 45.88 & 33.12 \\
BO & 79 & 109.25 & 49.75 & 102.58 & 56.42 \\
CA & 159 & 66.30 & 26.70 & 67.40 & 25.60 \\
CO & 93 & 82.06 & 28.94 & 72.19 & 38.81 \\
CL & 111 & 98.95 & 70.05 & 99.74 & 69.26 \\
DY & 169 & 66.34 & 33.66 & 65.77 & 34.23 \\
KE & 100 & 63.28 & 29.72 & 56.44 & 36.56 \\
LD & 93 & 73.57 & 27.43 & 74.00 & 27.00 \\
NC & 101 & 73.58 & 26.42 & 72.00 & 28.00 \\
SY & 100 & 100.21 & 48.79 & 101.40 & 47.60 \\
TO & 149 & 72.17 & 36.83 & 74.48 & 34.52 \\
PH & 109 & 68.49 & 28.51 & 69.07 & 27.93 \\
TS & 97 & 63.53 & 31.47 & 63.34 & 31.66 \\
YS & 95 & 106.11 & 49.89 & 104.06 & 51.94 \\
\hline
\end{tabular}




\section{DERIVING COMPETITIVE EDGE THROUGH INTEGRATED ABC-VCA MODEL}

It is well acknowledged that $A B C$ model provides precise information while evaluating an organization's processes and work flows to identify actual activities that cause costs. The accurate information thus presented through $A B C$ model creates value for managers by facilitating insight into potential sources of cost leadership. On the other hand, VCA is a technique that analyzes activities of the organization to reveal where its competitive advantages or disadvantages exist. But, it is observed that in contemporary business environment, information collected while employing traditional cost accounting systems is not sufficient and accurate for applying VCA model for optimal decision making. ABC model has emerged as a modern day cost accounting tool that enables the management of the organization to monitor costs more effortlessly and precisely because of its ability to perceive the behaviour of the costs from the strategic perspective, which allows seamless implementation of VCA technique to achieve a competitive position. The information derived from $A B C$ model assists administrators to manage and control one of two probable sources of competitive edge in value chain of enterprise, i.e. low cost production and low cost distribution.

Therefore, a combined ABC-VCA model is designed for application in BNL Limited. The managers benefit from business acumen provided through implementation of this integrated ABC-VCA model, which is valuable in comprehending the linkages and structure of the value chain and offering the foundation for recognizing several of the key constraints and policy issues that necessitate additional elucidation. The plan is to incite the policy makers to consider about the costs, position they attain in the structure of product value and their control on outlining the sales price since it is exceedingly imperative to manufacture exact products for the customers, of requisite superiority and functionality along with as minimum production costs as feasible. Porter [23] pointed out that each and every internal activity of an enterprise representing its value chain could be classified into primary activity that would attach value to the final product unswervingly and support activities that would add value indirectly. Here, a team consisting of managers and subject experts is formed to develop an exclusive VCA model for BNL Limited taking into account its activities, constraints and logistics. Batching (sole), mixing of raw material, sheeting (sole), sole pressing, sole cutting, drilling, printing, strap fitting, cleaning, inspection and quality control, batching (strap), kneeding, accelerator mixing, sheeting (strap), strap pressing and strap cutting are identified as the primary activities in the said organization that are directly concerned with manufacture and delivery of products. The secondary activities of BNL Limited consist of procurement, research and development, human resource management, and finance and accounting. These secondary activities are not straightforwardly associated with manufacturing of slippers in BNL Limited, but may increase effectiveness or efficiency of the production process. The integrated ABC-BSC model for the said department is shown in Figure 3.

It can be observed from the designed model that $A B C$ provides accurate information on individual costs of all the primary activities of value chain of BNL Limited so that the managers can either curtail some activities not creating value or remodel the operational processes aimed at minimizing total product cost. Moreover, detailed analysis of secondary activities of the said organization's value chain enabled through application of $A B C$ model enhances the transparency of costs in order to efficiently manage the activities. It can be noticed from the application of this integrated ABC-VCA model that the expenses incurred on strap fitting, sheeting (sole), mixing of raw material and sole pressing activities contribute towards more than $50 \%$ of the total overhead cost of the said footwear industry. Those four activities of value chain are decisive for competitive advantage of BNL Limited and thus, utmost care should be devoted for their planning, controlling and decision making. Thus, it can be comprehended that the developed integrated ABC-VCA model appropriately and accurately delineate activities of value chain into the ones that add value and the ones that do not attach worth to the product. This helps the management to have an insight into activities which creates the supreme value for customers or areas whose performance must be improved. 


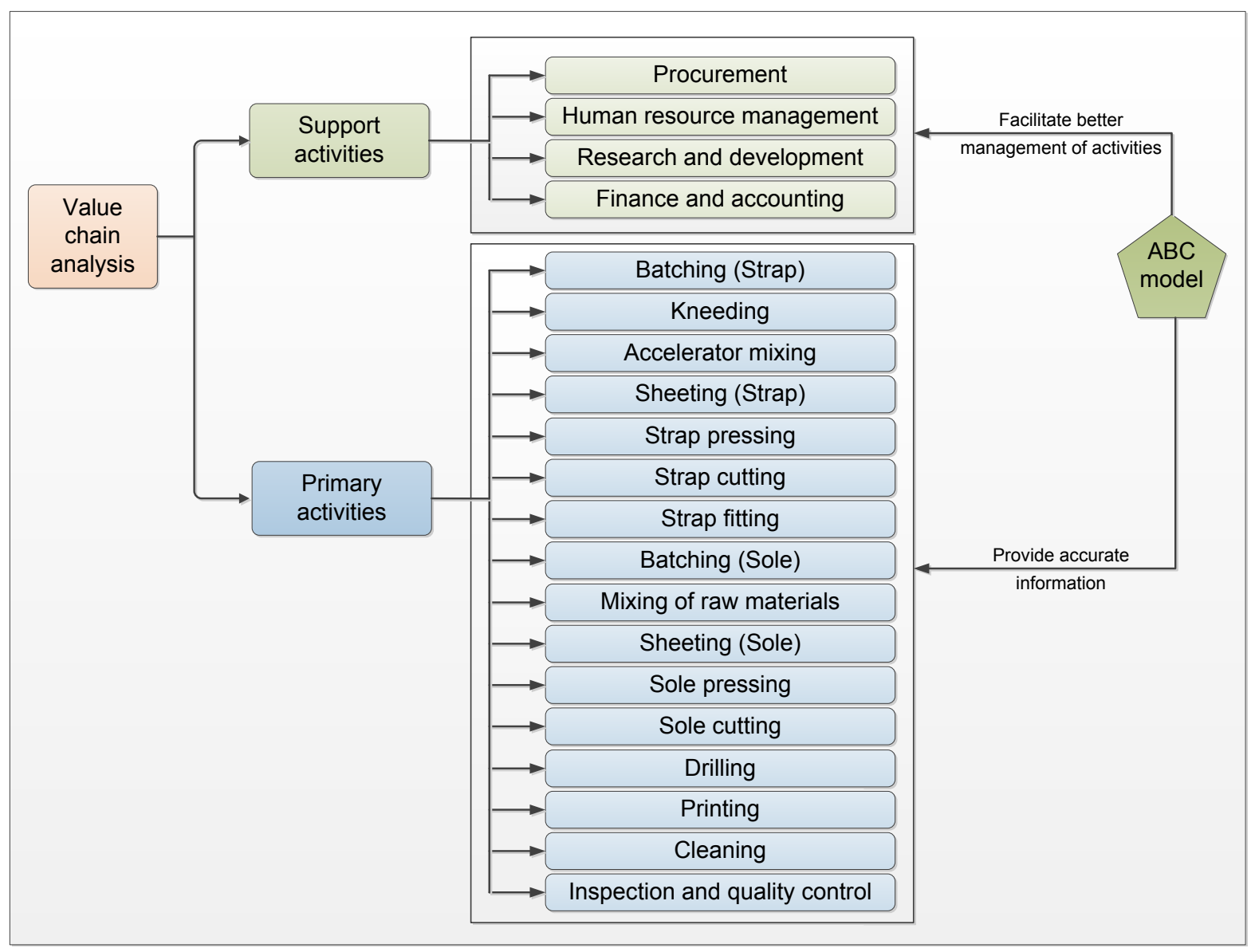

Figure 3. Integrated ABC-VCA model for BNL Limited

\section{CONCLUSIONS}

Contemporary organizations are constantly attempting to acclimatize, endure, perform and control. But, they are not all the time thriving to do the same. The business environment of modern day market is going through rapid and hastening change, resulting in escalating ambiguity and convolution. Enterprises always struggle in this hyper-competitive environment to achieve a sustained competitive position. In order to achieve it, they either position themselves strategically in their sector, or develop dependable and idiosyncratic organizational capabilities and resources through knowledge, learning and innovation. The $A B C$ model is a new management technique that helps managers to position their organizations expediently against their competitors through formulating new innovative strategies related to products, resources and market in order to satisfy varying demands of the customers. So, this paper proposes the application of $A B C$ model in a footwear industry to derive strategically relevant information about product profitability through accurately linking the consumption of resources to designated outputs. The result derived from implemented $A B C$ model in the said enterprise can help its management to understand in a better and more accurate way about the most profitable product line, optimal product mix, and best strategy to be effectively formulated and monitored. Additionally, a framework to integrate both $A B C$ and VCA models is provided for BNL Limited with a view to analyze the activities that take place in its value chain and relates them to a study of the competitive strength of the organization. The integrated ABCVCA model can help the policy makers in a more efficient and effective management of the value chain activities so as to deliver products to the customers in time devoid of compromising the requisite performances. Although these models are developed for an explicit industry, there is also enough future scope of their application to other industries. 


\section{REFERENCES}

1. Raz, T., Elnathan, D., Int J Proj Manage, 1999, 17, 1, 61-67.

2. Ridderstolpe, L., Johansson, A., Skau, T., Rutberg, H., Ahlfeldt, H., J Med Syst, 2002, 26, 4, 309-322.

3. Dickinson, V., Lere, J.C., Ind Market Manag, 2003, 32, 2, 301-307.

4. Hughes, A., Journal of Fashion Marketing and Management: An International Journal, 2005, 9, 1, 8-19.

5. Banker, R.D., Bardhan, I.R., Chen, T-Y., Account Org Soc, 2008, 33, 1, 1-19.

6. Stelling, M.T., Roy, R., Tiwari, A., Majeed, B., Serv Ind J, 2010, 30, 13, 2239-2260.

7. Carli, G., Canavari, M., Procedia Techn, 2013, 8, 397-405.

8. Mashayekhi, B., Hosseini, S.M.S., Attaran, N., Int J Manag Inform Techn, 2013, 5, 3, 229- 235.

9. Dwivedi, R., Chakraborty, S., Int J Innov Res Dev, 2014, 3, 12, 121-124.

10. Maiga, A.S., Advances in Accounting, 2014, 30, 2, 251-262.

11. Dwivedi, R., Chakraborty, S., International Journal of Accounting and Finance, 2015, 5, 1, 62-81.

12. Shama, M.S., Vinodh, S., Jayakrishna, K., Sci Iran Trans E, 2015, 22, 3, 1179-1188.

13. Tsai, W-H., Tsaur, T-S., Chou, Y-W., Liu, J-Y., Hsu, J-L., Hsieh, C-L., Int J Prod Res, 2015, $53,2,451-465$.
14. Dwivedi, R., Chakraborty, S., Bus Theory Pract, 2016, 17, 4, 289-298.

15. Taylor, D.H., Int J Phys Distrib Logist Manag, 2005, 35, 10, 744-761.

16. Souza, C.D.R.D., D’Agosto, M.D.A., Resour Conserv Recy, 2013, 78, 15-25.

17. Olson, E. L., J Clean Prod, 2014, 64, 73-80.

18. Thomas, F., Int J Tour Res, 2014, 16, 4, 368 376.

19. Tomić, V.P., Andrijašević, M., Megatrend Revija, 2014, 11, 4, 365-380.

20. Yan, L., Wang, A., Resour Conserv Recy, 2014, 91, 52-61.

21. Wang, L., Biomass Bioenerg, 2015, 78, 140 155.

22. Hamilton-Hart, N., Stringer, C., Mar Policy, 2016, 63, 166-171.

23. Porter, M.E., Competitive advantage creating and sustaining superior performance, The Free Press, New York, $1985,557$.

(C) 2017 by the author(s). Published by INCDTP-ICPI, Bucharest, RO. This is an open access article distributed under the terms and conditions of the Creative Commons Attribution license (http://creativecommons.org/licenses/ by/4.0/). 


\title{
CLASSIFICATION OF DIABETIC FEET IN TERMS OF RISK OF ULCERATION
}

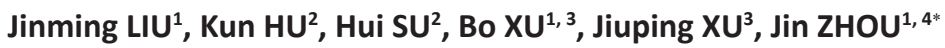 \\ ${ }^{1}$ National Engineering Laboratory for Clean Technology of Leather Manufacture, Sichuan University; Chengdu 610065, \\ P.R.China \\ ${ }^{2}$ Guangdong Huizhou Quality \& Measuring Supervision Testing Institute; Huizhou 516003, China \\ ${ }^{3}$ School of Business, Sichuan University; Chengdu 610065, P.R. China \\ ${ }^{4}$ Chengdu Anland Co., LTD; Chengdu 610065, P.R. China
}

Received: 13.03.2017

Accepted: 10.05 .2017

https://doi.org/10.24264/Ifj.17.3.2

\section{CLASSIFICATION OF DIABETIC FEET IN TERMS OF RISK OF ULCERATION}

\begin{abstract}
Diabetic feet are common complications in diabetes mellitus, but its classification in terms of risk of ulcer based on multiple measures was rear reported. Therefore the aim of this study was to establish a classification system for diabetic feet according to data from feet deformities, plantar pressures and peripheral neuropathy. This system comprised 13 categories with three main factors in varied levels: Feet deformities [Mild (one or without deformity), Moderate (two deformities) and Severe level (more than two deformities)], peripheral neuropathy (no, moderate and serious levels) and plantar pressure distribution ( $\leq 100 \% \mathrm{MP} * ; 100 \leq$ and $\leq 120 \% \mathrm{MP} *$; more than $120 \% \mathrm{MP}$, where "MP*" is the data of healthy population). Further, we conducted a case study to explain of our system, the results show that 32 patients with diabetes were divided into the following categories: 22 for I++, 8 for II+, 2 for IV+. Overall, This system can help the clinician detect the risk levels of feet and take necessary measures to prevent diabetic ulcers in feet.
\end{abstract}

KEY WORDS: diabetic feet, feet ulcers, classification of diabetic feet, feet deformity, plantar pressure distribution

\section{CLASIFICAREA PICIORULUI DIABETIC ÎN FUNCȚIE DE RISCUL DE ULCERATIIE}

REZUMAT. Piciorul diabetic reprezintă o complicație frecventă a diabetului zaharat, însă rareori s-a raportat clasificarea acestuia în ceea ce privește riscul de ulcerație pe baza mai multor măsurători. Prin urmare, scopul acestui studiu a fost de a stabili un sistem de clasificare pentru piciorul diabetic, în funcție de datele privind deformarea picioarelor, presiunea plantară și neuropatia periferică. Acest sistem a cuprins 13 categorii cu trei factori principali pe diverse niveluri: deformări ale picioarelor [ușoare (o singură deformare sau fără deformare), moderate (două deformări) și severe (mai mult de două deformări)], neuropatie periferică (lipsa acesteia, nivel moderat și nivel mare) și distribuția presiunii plantare ( $\leq 100 \% \mathrm{MP} * ; 100 \leq$ și $\leq 120 \% \mathrm{MP} *$; peste $120 \% \mathrm{MP} *$, unde "MP*” reprezintă datele populației sănătoase). Mai mult, s-a realizat un studiu de caz pentru a explica sistemul dezvoltat, iar rezultatele arată că 32 de pacienți cu diabet au fost împărțiți în următoarele categorii: 22 în categoria I++; 8 în categoria II+; 2 în categoria IV+. În ansamblu, acest sistem poate ajuta clinicianul să detecteze nivelurile de risc ale picioarelor și să ia măsurile necesare pentru prevenirea ulcerațiilor asociate cu piciorul diabetic.

CUVINTE CHEIE: picior diabetic, ulcerații la nivelul picioarelor, clasificarea piciorului diabetic, deformarea picioarelor, distribuția presiunii plantare

\section{CLASSIFICATION DES PIEDS DIABÉTIQUES SELON LE RISQUE D’ULCÉRATION}

RÉSUMÉ. Le pied diabétique est une complication fréquente dans le diabète sucré, mais sa classification selon le risque d’ulcération à partir des mesures multiples a été signalée rarement. Par conséquent, l'objectif de cette étude a été d'établir un système de classification pour le pied diabétique selon les données sur les déformations des pieds, les pressions plantaires et la neuropathie périphérique. Ce système a compris 13 catégories avec trois facteurs principaux sur des niveaux variés: les déformations des pieds [légères (une ou sans déformation), modérées (deux déformations) et sévères (plus de deux déformations)], la neuropathie périphérique (absence, niveaux modéré et sérieux) et la distribution de la pression plantaire ( $\leq 100 \% \mathrm{MP} * ; 100 \leq$ et $\leq 120 \% \mathrm{MP}$; ; plus de $120 \%$ MP*, où "MP*" signifie les données d'une population saine). En outre, on a réalisé une étude de cas pour expliquer notre système et les résultats montrent que 32 patients atteints de diabète ont été divisés dans les catégories suivantes: 22 pour I++; 8 pour II+; 2 pour IV+. Dans l'ensemble, ce système peut aider le clinicien à détecter les niveaux de risque des pieds et à prendre les mesures nécessaires pour prévenir les ulcères du pied diabétique.

MOTS CLÉS: pied diabétique, ulcères de pieds, classification du pied diabétique, déformation des pieds, distribution de la pression plantaire

\section{INTRODUCTION}

Diabetic feet refers to the lower limb of diabetic patients and it usually concerns the different degrees of peripheral vascular/ neuropathy disease, feet deformity, feet infection, ulcers or deep tissue damage [1]. Ulceration is also one of the most common and serious complications causing lower limb amputations for diabetes mellitus. As estimated, annual incidence of lower limb amputation was about $0.015 \%$ in current report, where half of them was attributed to the diabetic feet [2]. Besides, a heavy financial burden produced in diabetic population was 3 to 4 times higher than

*Correspondence to: Dr. Jin Zhou, National Engineering Laboratory for Clean Technology of Leather Manufacture, Sichuan University; Chengdu 610065, P.R.China; zj_scu@qq.com 
that of non-diabetics [3]. Therefore, it is essential to build a classification system to identify the risk of diabetic feet in terms of ulceration and then to make efforts to prevent the occurrence of ulcers.

Currently, the main methods for feet ulcer prevention are: (1) stressing the important of education in feet protection, as studies have shown that without enough education, the occurrence rates of amputation was 2 folds higher than the counterparts [4]; (2) screening the feet frequently [5]; (3) taking care of feet and choosing the right footwear [4]; (4) control diet and blood glucose. Among them, feet inspection, such as analysis of medical history, peripheral neuropathy measure $[6,7]$, plantar pressure test [8], feet deformity confirmation [9] and tissue thickness measure under skin by ultrasonic examination [10] or nuclear magnetic resonance [11] were important. However, current literature described the feet conditions by some aspects of the examination, for instance, diabetic peripheral neuropathy (DPN) merely combined the results of feet morphology inspection and feet peripheral neuropathy screen, other important information such as plantar pressure distribution was ignored. Hence, general outcomes in assessing the potential ulcer risk of diabetic feet could not be concluded.

Therefore, the aim of this study was to improve the traditional DPN approach and to establish an ulcer risk classification system for diabetic patients based on the assessment of feet deformity, plantar pressure and peripheral neuropathy. At last the diabetic feet can be explicitly classified into various groups and received differentiated treatment.

\section{METHODS}

\section{Method of Diabetic Feet Examination}

\section{Feet Deformities Inspection [9]}

Hallux valgus, hammer toe and claw toe belong to the categories of deformed feet. Hallux valgus occurs in the hallux and the MTH1, which can be expressed by the degree of the hallux valgus angle $(\mathrm{AOH})$. Hallux valgus angle $(\mathrm{AOH})$ can be measured by the relative position with hallux and MTH1 (Figure 1A). While, hammertoe refers to the deformity in hallux, which is in a vertical status and can greatly rise its pressure volume (Figure 1B); similarly, claw toe is similar to the hammer-toe, but the deformity occurs in the toe areas (Figure 1C). Those three deformities were usually observed in the diabetic patients [9]. However, as deformities such as pes planus or pes cavus were also common in the healthy population and whether they shall be considered as deformity or not has not been under the conclusion.

Numbers or types deformities were used to determine the feet deformities: Mild (one deformity or without deformity), Moderate (two deformities) and Severe level (multiple deformities).

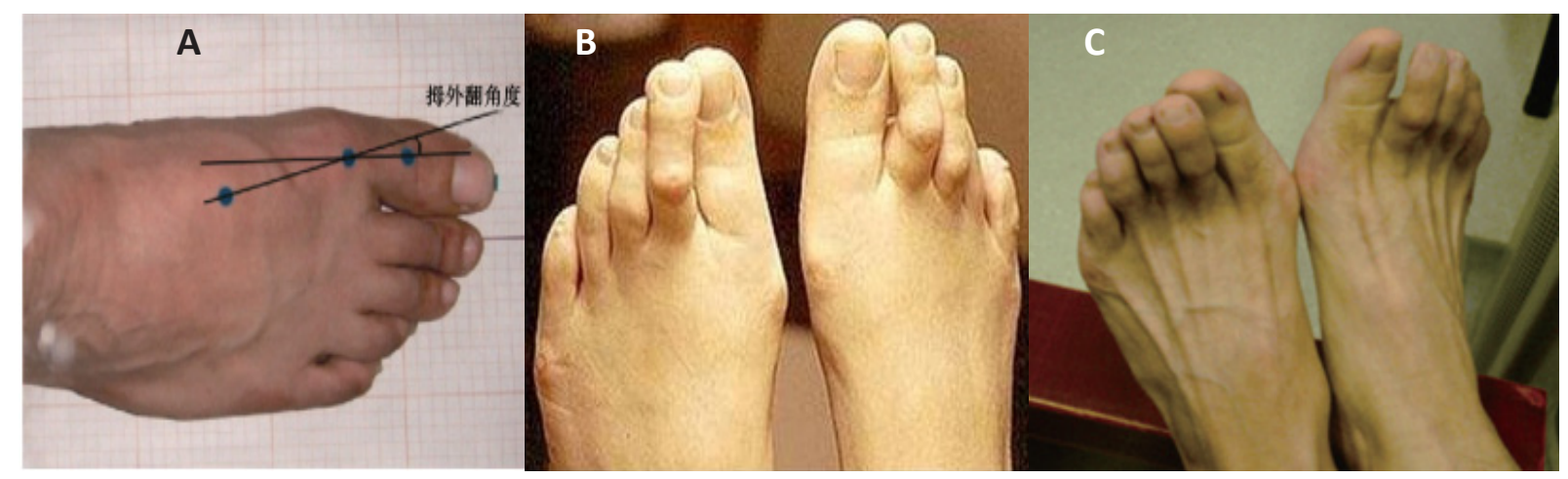

Figure 1. Samples of hallux valgus (A), hammer-toe (B) and claw toe (C)

Plantar Pressure Assessment [12]

Distribution of plantar forces was obtained by the Footscan plantar pressure system (one meter plate, RSscan Int., Belgium). The scanning frequency of this system is $250 \mathrm{~Hz}$, the pressure sensor density is $4 / \mathrm{cm}^{2}$ and the range of measurement is $0-200 \mathrm{~N} / \mathrm{cm}^{2}$. A two-step initial 
protocol [8] was performed by the subjects and they were guided to walk with their selected speed through the pressure plate, which was located and embedded in the middle of a sixmeter track. Before each measurement, the system was calibrated; and then a three to five minute warm up period was provided. At least three successful measures of each side of the foot were required in this study and they were averaged for further classification.

The plantar regions were divided by the Footscan software into 7 parts (Figure 1): the hallux, the first to fifth metatarsal heads $\left(1^{\text {st }}\right.$ to $\left.5^{\text {th }} \mathrm{MTH}\right)$ and the midfoot (MF), under which mean pressure (MP) $\left(\mathrm{N} / \mathrm{cm}^{2}\right)$ was calculated. The rearfoot areas such as medial heel and lateral heel were ignored, since seldom has ulcer occurred in those areas.

A group of healthy participants [94 healthy people (47 normal male / 47 normal female)] was measured to build a criterion. Their mean age of their counterparts is $64.0 \pm 7.4$ years, mean height is $157.0 \pm 7.4 \mathrm{~cm}$, body weight is $59.5 \pm 9.6$ $\mathrm{Kg}$ and mean $\mathrm{BMI}$ is $24.0 \pm 3.0$. Moreover, their MP at hallux is $13.1 \pm 8.6 \mathrm{~N} / \mathrm{cm}^{2}, \mathrm{MTH} 1$ is $9.1 \pm 7.4 \mathrm{~N} /$ $\mathrm{cm}^{2}, \mathrm{MTH} 213.6 \pm 7.6 \mathrm{~N} / \mathrm{cm}^{2}, \mathrm{MTH} 313.2 \pm 6.2 \mathrm{~N} /$

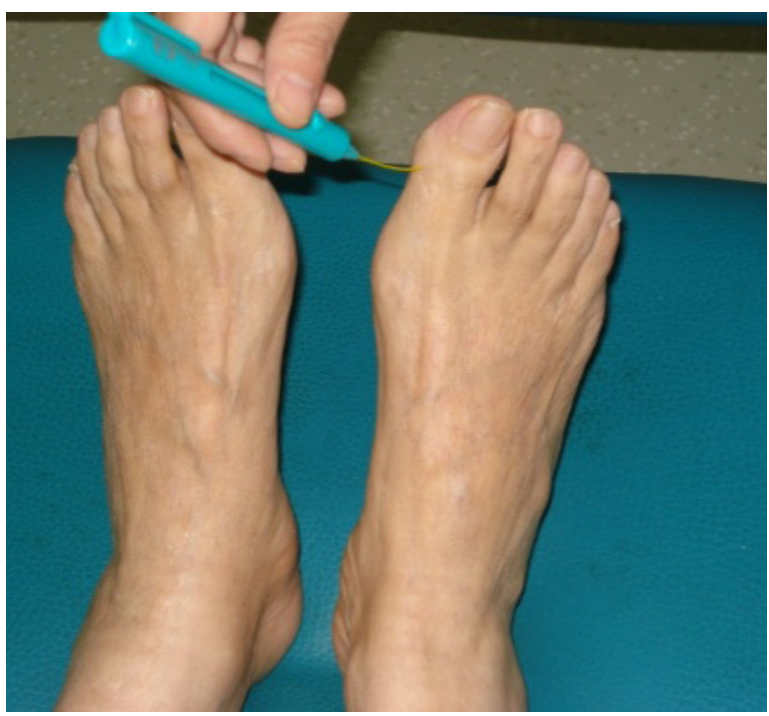

$\mathrm{cm}^{2}, \mathrm{MTH} 49.0 \pm 3.5 \mathrm{~N} / \mathrm{cm}^{2}, \mathrm{MTH} 5$ is $10.2 \pm 7.1 \mathrm{~N} /$ $\mathrm{cm}^{2}$, and $\mathrm{MF}$ is $4.4 \pm 2.2 \mathrm{~N} / \mathrm{cm}^{2}$.

\section{DPN (Diabetic Peripheral Neuropathy)}

DPN included the Michigan self-test and feet inspection. A standard Michigan self-test table was provided for the patients and feet inspection was made by an experienced staff which includes algesia and vibration check. The procedure of algesia test was made by $10 \mathrm{~g}$ Nylon monofilament [6]. Patient's bipedal toes were pressed by the monofilaments; then scores were calculated: 0 for normal feel, 1 for disappeared feel and 0.5 for the weakened feel (Figure 3 ). The tuning fork with vibration frequency of $128 \mathrm{~Hz}$ was placed in the bony protrusion of hallux [7] and score was given as 0 for normal with the feeling time <10s, 1 for disappear feel, and 0.5 for weakened with the feeling time $>10$ s (Figure 2). Moreover, the DPN was scored by the same scorer.

The classification of DPN was shown as: DPN score $=0$ indicates no peripheral neuropathy; $0<$ DPN score $<3$ implied moderate; $3<$ DPN score showed severe.

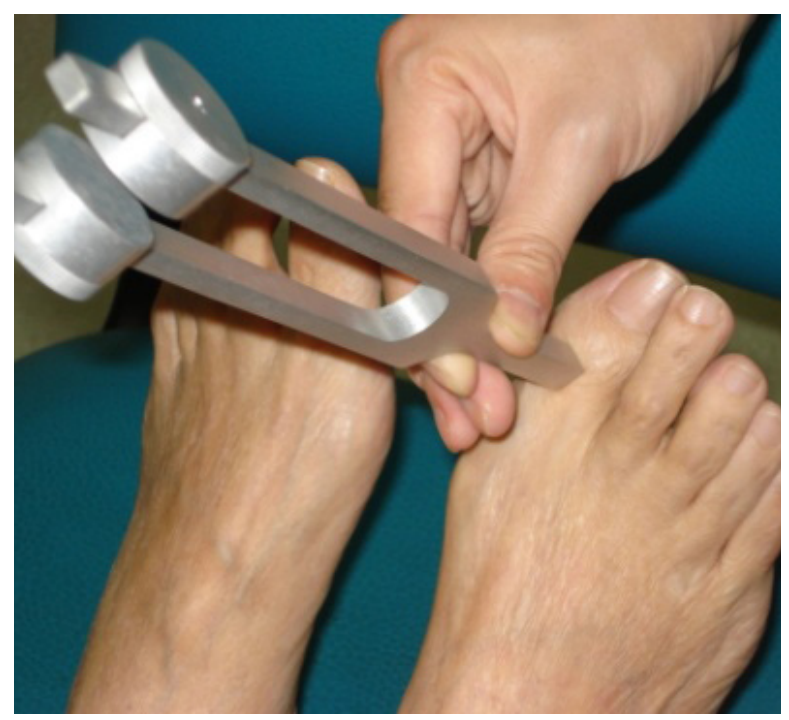

Figure 2. Demonstration of DPN test (A: algesia test; B: vibration test)

\section{Diabetic Feet Classification System}

In our systems, diabetic feet can be overall evaluated through three main factors in varied levels: Feet deformity [Mild (one deformity or without deformity), Moderate (two deformities) and Severe level (multiple deformities)],
Peripheral neuropathy (no, moderate and serious levels) and Plantar pressure distribution ( $\leq 100 \% \mathrm{MP}^{*} ; 100 \leq$ and $\leq 120 \% \mathrm{MP} *$; more than $120 \% \mathrm{MP}^{*}$, where "MP*" is the data of healthy population). So 13 categories were developed (Table 1). 
Table 1: System for diabetic feet classification

\begin{tabular}{|c|c|c|}
\hline & Category & Description \\
\hline I & $\begin{array}{l}\text { (mild / normal deformity) \& (normal DPN) \& (pressure } \\
\leq 100 \% \mathrm{MP}^{*} \text { ) }\end{array}$ & under healthy condition \\
\hline I+ & $\begin{array}{l}\text { (mild / normal deformity) \& (normal DPN) \& }(100 \% \\
\left.\text { MP* } \leq \text { pressure } \leq 120 \% \mathrm{MP}^{*}\right)\end{array}$ & $\begin{array}{l}\text { without feet deformity and peripheral neuropathy, but } \\
\text { with slightly high plantar pressure }\end{array}$ \\
\hline I++ & $\begin{array}{l}\text { (mild / normal deformity) \& (normal DPN) \& (pressure } \\
\geq 120 \% \mathrm{MP}^{*} \text { ) }\end{array}$ & $\begin{array}{l}\text { without feet deformity and peripheral neuropathy, but } \\
\text { with significantly high plantar pressure }\end{array}$ \\
\hline II & $\begin{array}{l}\text { (mild / normal deformity) \& (moderate DPN) \& } \\
\text { (pressure } \leq 100 \% \mathrm{MP}^{*} \text { ) }\end{array}$ & $\begin{array}{l}\text { without feet deformity, but with moderate peripheral } \\
\text { neuropathy }\end{array}$ \\
\hline II+ & $\begin{array}{l}\text { (mild / normal deformity) \& (moderate DPN) \& } \\
\text { (pressure } \geq 120 \% \mathrm{MP}^{*} \text { ) }\end{array}$ & $\begin{array}{l}\text { without feet deformity, but with moderate peripheral } \\
\text { neuropathy and significantly high plantar pressure }\end{array}$ \\
\hline III** & $\begin{array}{l}\text { (mild / normal deformity) + (severe DPN) \& (pressure } \\
\leq 100 \% \mathrm{MP}^{*} \text { ) }\end{array}$ & \\
\hline $\mathrm{IV} * *$ & $\begin{array}{l}\text { (moderate deformity) } \&(\text { normal DPN })+\left(100 \% \mathrm{MP}^{*} \leq\right. \\
\left.\text { pressure } \leq 120 \% \mathrm{MP}^{*}\right)\end{array}$ & \\
\hline IV+ & $\begin{array}{l}\text { (moderate deformity) \& (normal DPN) \& (pressure } \geq \\
120 \% \mathrm{MP}^{*} \text { ) }\end{array}$ & $\begin{array}{l}\text { with two deformities and significantly high plantar } \\
\text { pressure, without peripheral neuropathy }\end{array}$ \\
\hline V & $\begin{array}{l}\text { (moderate deformity) \& (moderate DPN) \& }(100 \% \\
\left.\mathrm{MP}^{*} \leq \text { pressure } \leq 120 \% \mathrm{MP}^{*}\right)\end{array}$ & $\begin{array}{l}\text { with two deformities, moderate peripheral neuropathy } \\
\text { and slightly high plantar pressure }\end{array}$ \\
\hline VI & $\begin{array}{l}\text { (moderate deformity) \& (severe DPN) \& }\left(100 \% \mathrm{MP}^{*} \leq\right. \\
\left.\text { pressure } \leq 120 \% \mathrm{MP}^{*}\right)\end{array}$ & $\begin{array}{l}\text { with two deformities, severe peripheral neuropathy and } \\
\text { slightly high plantar pressure }\end{array}$ \\
\hline $\mathrm{VII} * *$ & $\begin{array}{l}\text { (severe deformity) \& (normal DPN) \& (pressure } \geq 120 \% \\
\text { MP*) }\end{array}$ & \\
\hline VIII & $\begin{array}{l}\text { (severe deformity) \& (moderate DPN) \& (pressure } \geq \\
120 \% \mathrm{MP}^{*} \text { ) }\end{array}$ & $\begin{array}{l}\text { with multiple deformities, moderate peripheral } \\
\text { neuropathy and significantly high plantar pressure }\end{array}$ \\
\hline IX & $\begin{array}{l}\text { (severe deformity) \& (severe DPN) \& (pressure } \geq 120 \% \\
\text { MP*) }\end{array}$ & $\begin{array}{l}\text { with multiple deformities, severe peripheral neuropathy } \\
\text { and significantly high plantar pressure }\end{array}$ \\
\hline
\end{tabular}

*: MP of the healthy population

**: This situation is relatively rare (deformity and DPN are usually associated with high MP, or vice versa)

\section{CASE STUDIES}

In order to explain our system, we conducted a case study as shown below:

In this case study, diabetic patients were from Chengdu, including 19 males and 13 females; their height ranges from $151 \mathrm{~cm}$ to $182 \mathrm{~cm}$ and mean is $162.8 \pm 8.5 \mathrm{~cm}$; weight ranges from 40 to $120 \mathrm{~kg}$ and mean is $64.9 \pm 15.8 \mathrm{~kg}$; BMI ranges from 16.0 to 36.6 and mean is $24.3 \pm 4.4$. All the measures were executed after the details of this study were introduced to participants and their formal approvals were obtained. Moreover, all the measurements and procedures followed the principles of Helsinki Declaration.

In terms of feet deformities, there were 2 cases with moderate feet deformity, accounting for 6.25\%; while Michigan self-test score ranged
$0-5$ points and mean was $0.83 \pm 1.21$ points. Further, the number of regions belong to category of " $100 \%$ <plantar pressure <120\%" were: 1 for Hallux (left), 2 for MTH1 (left), 6 for MTH2 (left), 4 for MTH3 (left), 2 for MTH4 (left), 5 for MTH5 (left), 5 for MF (left); 1 for Hallux (right), 2 for MTH1 (right), 2 for MTH2 (right), 2 for MTH3 (right), 3 for MTH4 (right), 7 for MF (right). Those for the category of " $120 \%<$ plantar pressure" were: 9 for MTH1 (left), 16 for MTH2 (left), 25 for MTH3 (left), 26 for MTH4 (left), 12 for MTH5 (left), 8 for MF (left); 2 for Hallux (right), 9 for MTH1 (right), 17 for MTH2 (right), 23 for MTH3 (right), 24 for MTH4 (right), 10 for MTH5 (right), 7 for MF (right).

Thereby, according to the classification system, 32 patients with diabetes were divided 
into the following categories: 22 for I++; 8 for II+; 2 for IV+.

\section{DISCUSSION}

The structural change in the forefoot caused by hallux valgus resulted in the degradation of weight bearing function under hallux and first metatarsal head and the simultaneous worsening of the loading bearding at the lateral forefoot [13, 14]. Correlations between foot deformities and the changes of foot loading of the diabetic patient were widely reported in current literature. Mueller et al. [15] found that an increasing hallux valgus rendered the great toe less effective in weight bearing and a negative correlation was observed between high peak pressure and the great toe; while positive correlation existed between high peak pressure and first MTH. This was consistent with the study of Ahroni et al. [16] who systematically reviewed the risk factors for diabetic feet ulcer and they concluded that feet deformities significantly increased plantar pressure. However, conflicting results of hallux valgus were obtained by Ledoux et al. [14], but they also showed that claw toes and hammer toes were strongly correlated with the high pressure and the occurrence of feet ulcers. Based on the above studies, we chose the hallux valgus, hammer toes and claw toes as indicators for evaluating the degree of foot deformities by counting the number and type of deformities.

In terms of pressure distribution, Bus et al. [17] demonstrated that peak pressure of diabetic feet was more than $600 \mathrm{kPa}$ in a specific MTH area; meanwhile Bus et al. [18] also recommended that mean pressure $100 \mathrm{kPa}$ or peak pressure $200 \mathrm{kPa}$ shall be selected as target for pressure relieving. So in our study, we set two numbers as criterion: one is the $100 \%$ of healthy counterpart; another is the $120 \%$ of diabetic patients. In accordance with the healthy subjects, main loading area such as MTH1 has MP of $9.1 \pm 7.4 \mathrm{~N} / \mathrm{cm}^{2}$, the $120 \%$ of this value is $10.9 \mathrm{~N} / \mathrm{cm}^{2}(109 \mathrm{kPa})$ which reached the level recommended in the literature. Hence, we deemed that $120 \%$ MP of healthy population was enough to detect the risk of pressure distribution.

In our practice, with the assistance of this system based on evaluation of foot deformity, plantar pressure and peripheral neuropathy, the clinician can easily classify the patients into varied groups and further prescription can be made accordingly. However, limitations existed in our study: (1) only the three types of deformity were considered in this study, where those of the amputated feet or feet with ulceration were not recruited in this study; (2) the peak pressure under the rear feet such as medial and lateral heel were not considered in this study; (3) validities of this system shall be improved by application of more cases. Nevertheless, this part of work will be continuously carried out in the future.

\section{CONCLUSION}

Overall, In this study, we developed a classification system based on assessment of feet deformity, plantar pressure and peripheral neuropathy. This system can help the clinician detect the risk levels of feet and take necessary measures to prevent diabetic ulcers in feet.

\section{Acknowledgement}

The authors thank the financial support from China Postdoctoral Science Foundation (2015M571896) and project from Chengdu science and technology administration (2015-HM01-00039-SF).

\section{REFERENCES}

1. International Diabetes Feet Working Group, International Consensus on the Diabetic Feet, 2003.

2. Apelqvist, J., Larsson, J., Diabetes Metab Res Rev, 2000, 16, 75-83.

3. Li, Q., Wang, P.H., Yan, L., Du, Y.M., Bian, R.W., Wang, Z.J., Mao, J.P., Xiao, Z.H., Ma, X.Y., Lin, S.D., Chen, G.C., Zhou, Y.S., Xu, Z.R., Chinese Journal of Endocrinology and Metabolism, 2005, 21, 496-499.

4. Coleman, W.C., Brand, P.W., Ellenberg and Rifkin's Diabetes Mellitus, 1997, 1159-1182.

5. The American Diabetes Association, Diabetes Care, 1998, 21, 554-555.

6. McGill, M., Molyneaux, L., Spencer, R., Heng, L.F., Yue, D.K., Diabetes Care, 1999, 22, 598602. 
7. Xu, Z.R., Chinese Journal of Endocrinology and Metabolism, 2005, 6, 491-493.

8. Barnett, S., Diabetic Feet, 1998, 1, 72.

9. Zhou, J., Xu, B., Principle of the Last Design, 2016, 65-69.

10. Boulton, A.J.M., Diabetologia, 2004, 49, 1342-1353.

11. Li, Q.X., Medicine and Philosophy, 2008, 29, 14-17.

12. Wang, A.H., Li, J.L., Xu, Z.R., Wang, Y.Z., Liu, Y., Chin J Endocrinol Metab, 2005, 21, 500-501.

13. Hutton, W.C., Dhanendran, M., Clin Orthop Relat Res, 1981, 157, 7-13.

14. Ledoux, W.R., Shofer, J.B., Smith, D.G., Sullivan, K., Hayes, S.G., Assal, M., Reiber, G.E., J Rehabil Res Dev, 2005, 42, 5, 665-672.
15. Mueller, M.J., Hastings, M., Commean, P.K., Smith, K.E., Pilgram, T.K., Robertson, D., Johnson, J., J Biomech, 2003, 36, 1009-1017.

16. Ahroni, J.H., Boyko, E.J., Forsberg, R.C., Diabetes Care, 1999, 22, 965-972.

17. Bus, S.A., Maas, M., de Lange, A., Michels, R.P., Levi, M., J Biomech, 2005, 38, 19181925.

18. Bus, S.A., Haspels, R., Buschwestbroek, T.E., Diabetes Care, 2011, 34, 7, 1595.

C 2017 by the author(s). Published by INCDTPICPI, Bucharest, RO. This is an open access article distributed under the terms and conditions of the Creative Commons Attribution license (http://creativecommons.org/licenses/by/4.0/). 


\title{
COURT SHOE PRODUCTION LINE: IMPROVEMENT OF PROCESS CYCLE EFFICIENCY BY USING LEAN TOOLS
}

\author{
Md. Abu SAYID MIA ${ }^{1,2^{*}}$, Md. NUR-E-ALAM ${ }^{3}$, M. Kamal UDDIN ${ }^{2}$ \\ ${ }^{1}$ Institute of Leather Engineering and Technology, University of Dhaka, Dhaka-1209, Bangladesh \\ ${ }^{2}$ Institute of Appropriate Technology, Bangladesh University of Engineering and Technology, Dhaka-1000 \\ ${ }^{3}$ Leather Research Institute (LRI), Bangladesh Council of Scientific and Industrial Research, Savar, Dhaka-1350, Bangladesh
}

COURT SHOE PRODUCTION LINE: IMPROVE PROCESS CYCLE EFFICIENCY BY USING LEAN TOOLS

ABSTRACT. Lean manufacturing is an applied methodology of scientific, objective techniques that cause work tasks in a process to be performed with a minimum of non-value adding activities resulting in greatly reduced wait time, queue time, move time, administrative time, and other delays. This work addresses the implementation of lean principles in a footwear manufacturing industry in order to evaluate present Process Cycle Efficiency (PCE) and lead time prior to developing an improved strategy to bring the improved PCE and to reduce the lead time. At the present state, the PCE was found $8.32 \%$ and after the implementation of lean tools, it would be $19.46 \%$ at the future state where lead time would also be reduced by $57.24 \%$ evaluated by Pareto analysis and value stream mapping (VSM) tools. The production flow was optimized by minimizing several non-value added activities and time such as bottlenecking, machine breakdown, queue time, waiting time, material handling time, etc. Eventually, this study will be useful in developing a more generic approach to design lean environment in the management system of the studied " $X$ " Footwear Industry in Bangladesh.

KEY WORDS: lean tools, VSM, lead time, PCE, technology assessment, court shoe, Bangladesh

LINIE DE PRODUCTIE A PANTOFILOR CLASICI: ÎMBUNĂTĂTIREA EFICIENTEI PROCESULUI PRIN UTILIZAREA INSTRUMENTELOR SUPLE REZUMAT. Producția suplă este o metodologie aplicată pe baza unor tehnici științifice și obiective care presupune ca sarcinile de lucru din cadrul unui proces să fie realizate cu un minim de activități fără valoare adăugată, ceea ce are ca rezultat reducerea timpului de așteptare, timpului de mișcare, timpului de administrare și altor întârzieri. Această lucrare abordează implementarea unor principii suple într-o fabrică de încălțăminte pentru a evalua eficiența ciclului de proces (PCE) existent și timpul de execuție înainte de a dezvolta o strategie pentru a îmbunătăți PCE și pentru a reduce timpul de execuție. În starea actuală PCE a fost estimat la 8,32\%, iar după punerea în aplicare a instrumentelor suple, ar crește în viitor la 19,46\%, iar timpul de execuție ar fi redus cu 57,24\%, evaluat prin analiza Pareto și instrumentele de cartografiere a fluxului de valori (VSM). Fluxul de producție a fost optimizat prin reducerea la minimum a mai multor activități și timpi fără valoare adăugată, cum ar fi blocajele, defectarea mașinilor, timpul de așteptare, timpul de manipulare a materialelor etc. În cele din urmă, acest studiu va fi util în dezvoltarea unei abordări mai generice pentru proiectarea unei producții suple în sistemul de management al fabricii de încălțăminte „X" din Bangladesh.

CUVINTE CHEIE: instrumente suple, VSM, timp de execuție, PCE, evaluarea tehnologiei, pantofi clasici, Bangladesh

LIGNE DE PRODUCTION DES CHAUSSURES CLASSIQUES: AMÉLIORER L’EFFICACITÉ DU PROCÉDÉ EN UTILISANT LES OUTILS DE GESTION ALLÉGÉE

RÉSUMÉ. La production allégée est une méthodologie appliquée à partir des techniques scientifiques et objectives qui impliquent que les tâches de travail dans un processus soient réalisées avec un minimum d'activités à valeur ajoutée, entraînant la réduction des temps d'attente, des temps d'administration et d'autres retards. Cet article traite de la mise en œuvre de principes de gestion allégée dans une entreprise de fabrication de chaussures pour évaluer l'efficacité du cycle de processus existant (PCE) et du temps d'exécution avant d'élaborer une stratégie pour améliorer le PCE et réduire le temps d'exécution. Dans l'état actuel, le PCE a été estimé à 8,32\% et, après la mise en œuvre des outils de gestion allégée, il augmenterait à 19,46\% à l'avenir et le temps d'exécution serait réduit de 57,24\%, évalué par l'analyse de Pareto et les outils de cartographie du flux de valeur (VSM). Le flux de production a été optimisé en minimisant les multiples activités et les temps sans valeur ajoutée tels que les goulots d'étranglement, les pannes de machines, les temps d'attente, les temps de traitement des matériaux, etc. Enfin, cette étude sera utile pour développer une approche plus générique pour concevoir une production allégée dans le système de gestion de l'entreprise de fabrication de chaussures " $\mathrm{X}$ " du Bangladesh.

MOTS CLÉS: outils de gestion allégée, VSM, temps d'exécution, PCE, évaluation de la technologie, chaussures classiques, Bangladesh

\section{INTRODUCTION}

Lean manufacturing is based on the Toyota Production System developed by Toyota which focuses on eliminating waste, reducing inventory, improving throughput, and encouraging employees to bring attention to problems and suggest improvements to fix them [1]. Lean manufacturing has increasingly been applied by leading manufacturing companies throughout the world. Today Higher Productivity achievement is the very important factor for the production field [2]. A core concept of lean manufacturing is pulling production in

\footnotetext{
* Correspondence to: Md. Abu Sayid MIA, Institute of Leather Engineering and Technology, University of Dhaka, Dhaka-1209, Bangladesh,
} E-mail: emsayid@gmail.com, Contact: +8801674772545 
which the flow on the factory floor is driven by demand from downstream pulling production upstream. Some of the changes required by lean manufacturing can be disruptive if not implemented correctly and some aspects of it are not appropriate for all companies [3]. A lean manufacturing facility is capable of producing the product in only the sum of its value added work content time. On the other hand, applications of lean manufacturing in the continuous process sector have been far fewer [4]. It has sometimes been argued that in part, this is because such industries are inherently more efficient and have a relatively less urgent need for major improvement activities. Managers have also been hesitant to adopt lean manufacturing tools and techniques to the continuous sector because of other characteristics that are typical in this sector. These include large, inflexible machines, long setup times, and the general difficulty in producing in small batches. While some lean manufacturing tools might indeed be difficult to adapt to the continuous sector, this does not mean that the approach is completely inapplicable; for example, [5-11] examine aspects of continuous production that are amenable to lean techniques and present a classification scheme to guide lean implementation in this sector. Features of a typical lean manufacturing model include one unit at a time production; non-value added time eliminated production in the work content time only, and relocation of required resources to the point of usage. In the present day of manufacturing, the assembly line can be formed easily for any industry whether it is a small-scale or a large-scale industry. When the takt times are calculated for every part manufactured in the industry through different part movements, then the problem of locating machines on the shop floor occurs when it is a job type production unit; this problem is the main reason for reconfiguration of machines and layout design for every demand [12]. To eliminate these problems, a proper method is required to achieve a rhythm in manufacturing lean assembly line by identifying value adding, non-value adding, and necessary non-value adding activities through an optimum feasible takt time [13]. This study had the specific objectives to identify, quantify and to reduce the non-value added (NVD) activities and time towards the exalted Process Cycle Efficiency (PCE) and therefore to reduce the lead time.

\section{INDUSTRIAL IMPLEMENTATIONS OF LEAN TOOLS}

With the flow of time and iridescent aptitude of the consumer, today's manufacturing industries are undergoing more and more competition in local and global marketing system to come up with the desired product or service within a limited period of time. Towards reducing the lead time, improving the PCE and ultimately to gain the benefit there is compelling evidence of successful lean tools implementation in the manufacturing world. Lean tools have been successfully applied in many manufacturing organizations such as General Electric, Boeing, DuPont, Kodak, Honeywell, Texas Instruments, etc [14]. Lean tools are also successfully applied in hospitals, pharmaceutical, housing and paper industry, and brought with alluring economic benefit by reducing the long lead time and manufacturing waste. It was estimated that over the world by adopting lean tools in pharmaceutical industry a cost could be saved up to $\$ 90$ billion per year [15]. In 1999, it was evaluated that lean tools significantly brought the benefits of $\$ 20$ billion to Motorola Inc. since 1986 that inspired many companies in various industrial sectors to adopt lean tools. In the USA, it was reported that a food manufacturing industry has gained the benefit of $\$ 2$ million per year by adopting lean tools [16]. This riveting economic benefit was the ultimate outcome of reduced NVD activities, lead time and improved PCE. It was shown a frozen fish industry would able to improve its PCE from $5.02 \%$ to $17.46 \%$ by adopting lean tools [17]. Like these promising studies, the authors were provoked to conduct this study with the lean tools in a court shoe production line of a footwear manufacturing company in Bangladesh prior to reducing the lead time and to improve the PCE. The demand of processed footwear is rapidly increasing in the busy world and consequently, it seems there is a rapid expansion of footwear industry in Bangladesh similarly to other countries [18]. 


\section{OBSERVED PRODUCTION LINE}

In this study, the required materials towards the finished court shoe were not the concerning matter rather than causes that were responsible for production waste and down time. The delay in production due to different causes and downtime were quantified in terms of NVD time. The basic stages of court shoe production line are shown in the following Figure 1.

\section{Value Stream Mapping (VSM)}

A value stream is a collection of all actions (value added as well as non-value-added) that are required to bring a product (or a group of products that use the same resources) through the main flows, starting with raw material and ending with the customer. These actions consider the flow of both information and materials within the overall supply chain. The ultimate goal of VSM is to identify all types of waste in the value stream and to take steps to try and eliminate these [19]. While researchers have developed a number of tools to optimize individual operations within a supply chain, most of these tools fall short in linking and visualizing the nature of the material and information flow throughout the company's entire supply chain. Taking the value stream viewpoint means working on the big picture and not individual processes. VSM creates a common basis for the production process, thus facilitating more thoughtful decisions to improve the value stream [20].

\section{Present Value Steam Mapping (VSM) of Court Shoe Production Line}

To draw the present VSM relevant data in the following Figure 2 as VD and NVD time, Cycle time $(C / T)$, Change Over time, Uptime $(U / T)$,

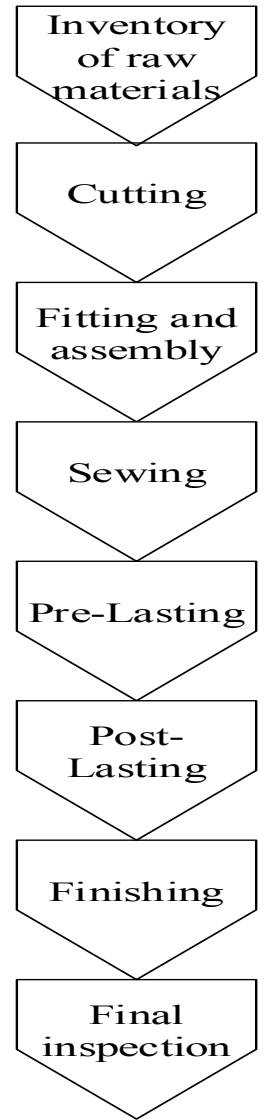

Figure 1. Basic stages of Court shoe production line

Lot size, quantity to deliver, delivery time were observed and information related to assembly line such as production time, inventory storages, inspections, rework loops, number of workers and operational hours per day were collected and documented in Table 1 and Table 2. To draw the completion of present VSM of Court shoe production line, a timeline was added at the bottom of the map recording the VD and NVD time.

Table 1: Manufacturing lead time of Court Shoe Production Line

\begin{tabular}{cccccccccc}
\hline Times & \multicolumn{3}{c}{ Sewing } & \multicolumn{4}{c}{ Lasting } & \multicolumn{3}{c}{ Finishing } \\
& $\mathrm{D} / \mathrm{T}(\mathrm{Sec})$ & $\mathrm{C} / \mathrm{T}(\mathrm{Sec})$ & $\mathrm{U} / \mathrm{T}(\%)$ & $\mathrm{D} / \mathrm{T}(\mathrm{Sec})$ & $\mathrm{C} / \mathrm{T}(\mathrm{Sec})$ & $\mathrm{U} / \mathrm{T}(\%)$ & $\mathrm{D} / \mathrm{T}(\mathrm{Sec})$ & $\mathrm{C} / \mathrm{T}(\mathrm{Sec})$ & $\mathrm{U} / \mathrm{T}(\%)$ \\
\hline $1^{\text {st }}$ & 474 & 2760 & 83 & 862 & 2400 & 64 & 384 & 1620 & 76 \\
$2^{\text {nd }}$ & 487 & 2760 & 82 & 869 & 2400 & 64 & 385 & 1620 & 76 \\
$3^{\text {rd }}$ & 474 & 2760 & 83 & 849 & 2400 & 65 & 388 & 1620 & 76 \\
\hline
\end{tabular}

Note: Sewing m/c speed: 350 RPM; Lasting m/c speed: 400 RPM; finishing m/c speed: 15 cases per min. Batch production-4000 pairs. 
Table 2: Present lead time of Court Shoe Production Line

\begin{tabular}{ccc}
\hline Production stages & VD time (Sec) & NVD time (Sec) \\
\hline Receiving inventory & 00 & 28800 \\
Cutting & 600 & 1200 \\
Fitting \& Assembly & 1200 & 240 \\
Sewing & 2297 & 703 \\
Pre-lasting & 00 & 672 \\
Post-lasting & 1650 & 1372 \\
Finishing & 1231 & 702 \\
Shipping inventory & 00 & 43200 \\
Total & $6978(8.32 \%)$ & $76889(91.68 \%)$ \\
\hline
\end{tabular}

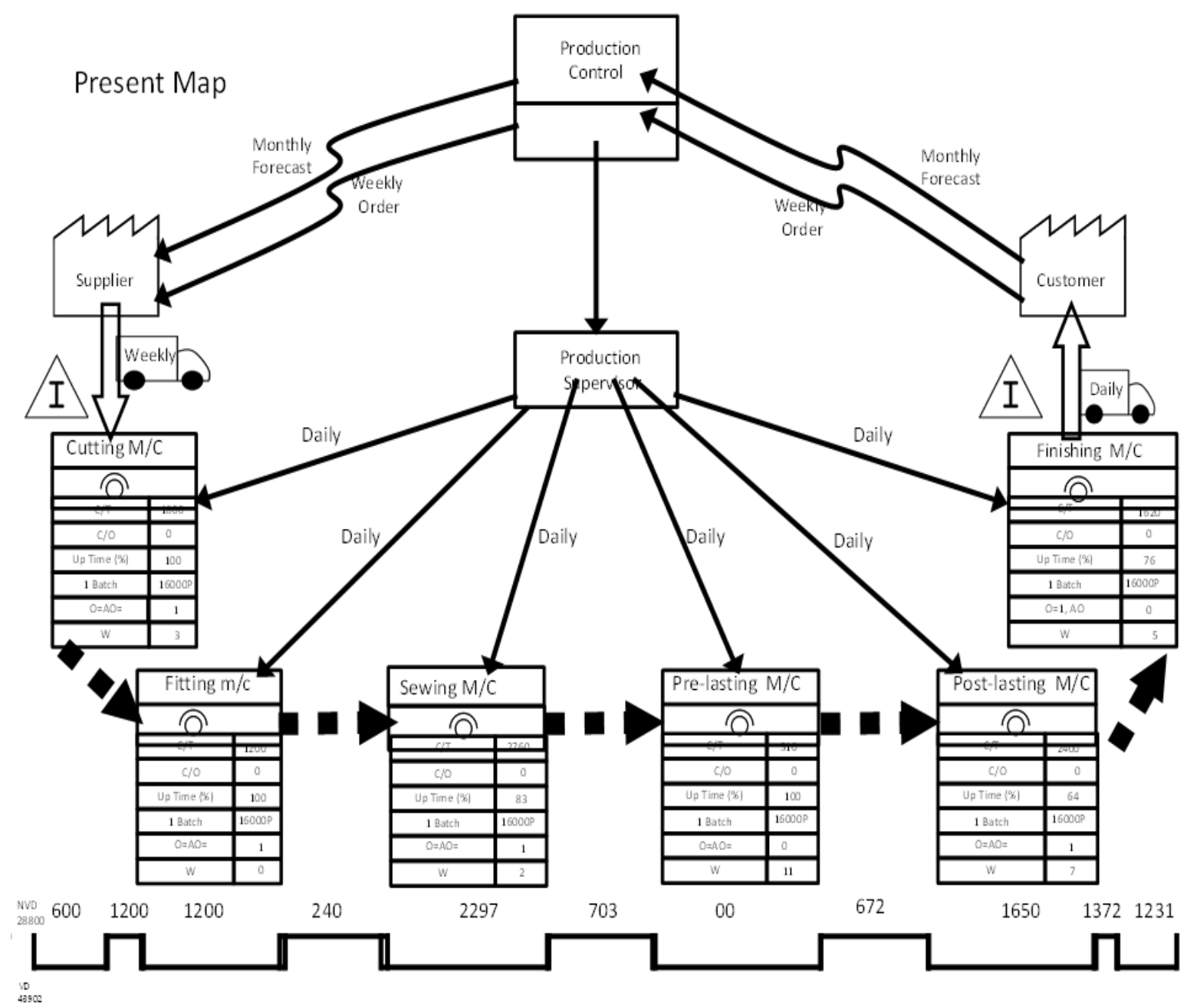

Figure 2. Present Value Steam Mapping (VSM) of Court Shoe Production Line 
It helps to draw the required production steps with mentioning required labor, $\mathrm{C} / \mathrm{T}, \mathrm{U} / \mathrm{T}$, $\mathrm{C} / \mathrm{O}$ and batch size. By observing the present scenario regarding production line, the following questions can be answered: how much labor is needed at different production units? How much is VD \& NVD time present? Where \& what kind of improvement should be done? It helps to calculate the PCE, lead time and takt time.

\section{Present PCE of Court Shoe Production Line}

PCE is measured as the percentage of the ration of VD time and lead time, where lead time is the summation of VD and NVD time. In the observed production line, the VD and NVD time were found as $6978 \mathrm{sec}$ and $76889 \mathrm{sec}$, so the lead time was $83867 \mathrm{sec}$ and consequently, the PCE was $8.32 \%$ which could be considered below the internationally comparative level $25 \%$ [17]. Throughout this study, it was strived to improve the present PCE with the proper adoption of lean tools such as VSM, Pareto analysis, Pareto chart, 5S, and JIT.

\section{Present Takt Time of Court Shoe Production Line}

Takt time is considered as the time that is required to produce a single unit of daily capable quantity of commodities [21]. The studied production line runs for two shifts per day, each shift was for $33600 \mathrm{sec}$ excluding lunch time and planned down time; therefore, the available time for the run of the studied production line was $67200 \mathrm{sec}$ with the daily customer demand of 9333 cases where each case contains 250 pairs court shoe and every shoe size is UK 9. Takt time is considered as the heartbeat of any process line. By this way, the present takt time of studied production line was $7.20 \mathrm{sec}$ i.e. it took $7.20 \mathrm{sec}$ to produce a single case of court shoe production. By this study, it was tried to reduce the present takt time with the proper implementation of lean tools.

\section{Pareto Analysis}

It is a statistical technique in decision making that is used for selection of a limited number of tasks that produce significant overall effect. It uses the Pareto principle - the idea that by doing $20 \%$ of work, $80 \%$ of the advantage of doing the entire job can be generated. Or in terms of quality improvement, a large majority of problems $(80 \%)$ are produced by a few key causes (20\%) [22]. The Pareto Principle is also known as the "80/20 Rule" which is the idea that $20 \%$ of causes generate $80 \%$ of results [2325]. In this study, by using this tool it was tried to find out the $20 \%$ of causes that is generating $80 \%$ NVD activities. This tool focuses on the most damaging causes on a project. In this essence, David stated that the application of the Pareto chart consisting of causes for downtime or NVD activities along the $X$ axis while the $Y$ axis represents the cumulative percentage of downtime. Most of the NVD activities were documented on sewing, pre-lasting, post-lasting and finishing steps where these were frequently observed due to different causes. The highest frequency of NVD activities that derived the down time was found for toe lasting problems while skipped stitches were the lowest frequency.

Table 3: Causes of delay times for Pareto analysis of Court Shoe Production Line

\begin{tabular}{cccc}
\hline Causes of delay times & Down Time (D/T) & Percentage of D/T & Cumulative of percentage \\
\hline Toe lasting problems & 526 & 30.4750869 & 30.4750869 \\
Needle thread breakage & 303 & 17.5550406 & 48.03012746 \\
Inefficient ironing & 171 & 9.90730012 & 57.93742758 \\
Seat lasting problems & 103 & 5.96755504 & 63.90498262 \\
Inappropriate scouring & 97 & 5.61993048 & 69.52491309 \\
Inappropriate chilling & 91 & 5.27230591 & 74.797219
\end{tabular}




\begin{tabular}{cccc} 
Improper polishing & 91 & 5.27230591 & 80.06952491 \\
Seam pucker & 89 & 5.15643105 & 85.22595597 \\
Bobbin thread breakage & 53 & 3.07068366 & 88.29663963 \\
Side lasting problems & 43 & 2.49130939 & 90.78794902 \\
Inefficient spraying & 42 & 2.43337196 & 93.22132097 \\
Long mark defects & 41 & 2.37543453 & 95.5967555 \\
Bumps or hollows & 41 & 2.37543453 & 97.97219003 \\
Skipped stitches & 35 & 2.02780997 & 100 \\
\hline
\end{tabular}

Different causes of NVD activities or down time at different production stages were documented in Table 3 with their frequency in terms of percentage and cumulative of percentage. Pareto chart is constructed in Figure
3 where the responsible causes for NVD activities were arranged in downward movements in terms of their frequency. $5 \mathrm{~S}$ and JIT would be effective initiatives to remove these most frequent causes.

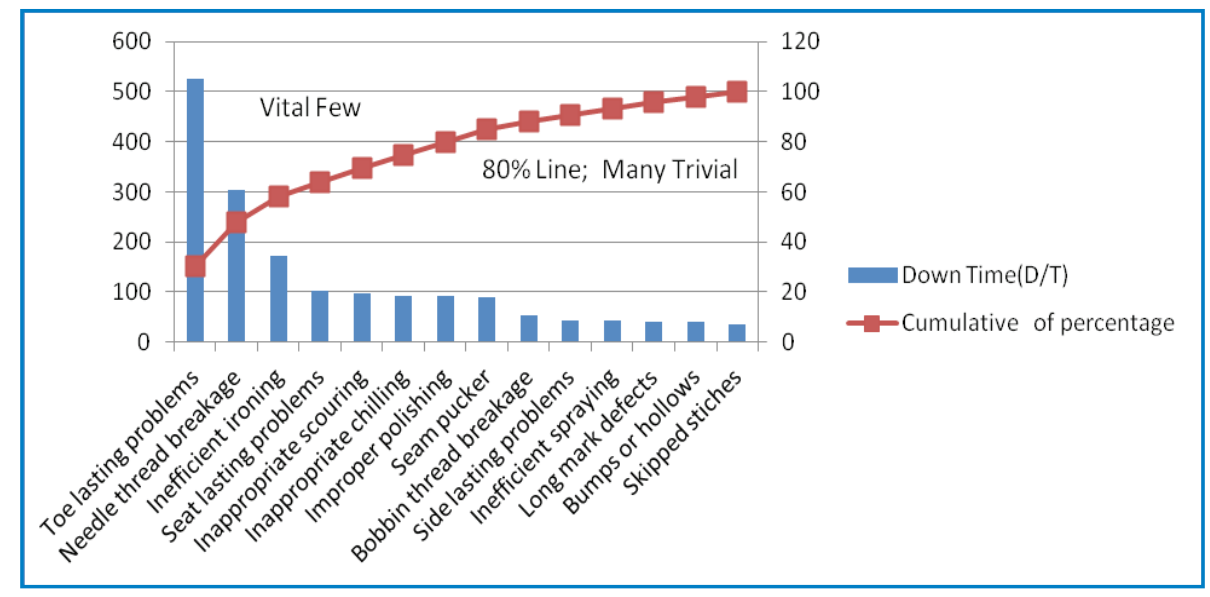

Figure 3. Pareto chart of Court Shoe Production Line

\section{IMPROVEMENT STRATEGIES}

In order to remove the $80 \%$ NVD activities, some improvement strategies are required such as increasing skilled manpower, continuous improvement, and involvement of JIT philosophy within the production management system.

\section{Increase Skill Manpower}

It was observed that most of the assistant operators were not skilled enough to handle the machine breakdown immediately. But for this reason, the maintenance time was as high as not acceptable. So, it is suggested to hire some skilled manpower as operator and assistant operator especially for sewing, lasting and finishing machine. The effective training program should be arranged prior to make capable of operator and assistant operator towards reducing the maintenance time.

\section{Continuous Improvement}

Continuous improvement is one of the most effective and basic tools of lean production which is also known as Kaizen. It is a longterm approach to work systematically to seek and to achieve small, incremental changes in processes in order to improve the efficiency and quality. Kaizen can be applied to any kind of work, but it is well known for being used in lean manufacturing. Kaizen is a Japanese term that reveals the meaning as "good change". Basically Kaizen is considered as a systematic approach for continuous improvement. $5 \mathrm{~S}$ is one of the most popular tools for effective continuous improvement. Towards the NVD activities reduction, $5 S$ is the first modular step. $5 S$ is 
not only a means to increase the profitability of a firm but also allow companies to reveal potential strengths and capabilities that were hidden before [26]. It consists of Japanese words - Seiri (Sort), Seiton (Straighten), Seiso (Sweep and Clean), Seiketsu (Systemize), and Shitsuke (Standardize). The basic and underlying concept of $5 \mathrm{~S}$ is looking for waste and then trying to eliminate it. This concept implies instantly going where there is a problem, checking out the problem, taking a temporary measure on the spot, finding out the main causes beyond the problem, if necessary using the five WHY? Questions; and finally standardizing to prevent reoccurrence [27]. In a production process line, a good change or the improvement can be achieved in many ways such as reduction of inventory, reduction of production time, reduction of defective parts etc. In this essence, a strategic plan is developed prior to implementing the $5 \mathrm{~S}$ in the observed Court Shoe production line in order to remove the recognized NVD activities. Towards the implementation of 5S, a proper plan or vision is required which could be formulated by the management of footwear sector. The vision plan should be incorporated with the theme of reducing lead time, NVD activities or manufacturing waste and improving PCE. The implemented $5 \mathrm{~S}$ plan consists of team work, training work, multi skill scope and learning environment. To implement a new plan, a team work will be an effective wheel to bring the plan into practice. An effective training program should be arranged frequently prior to need for the sake of $5 \mathrm{~S}$ incorporation within the existing production management system. There should be a constant attempt to find out the problem at each and every stage of the Court Shoe production line. A persistent endeavor should be kept on creating a way to eliminate the arising

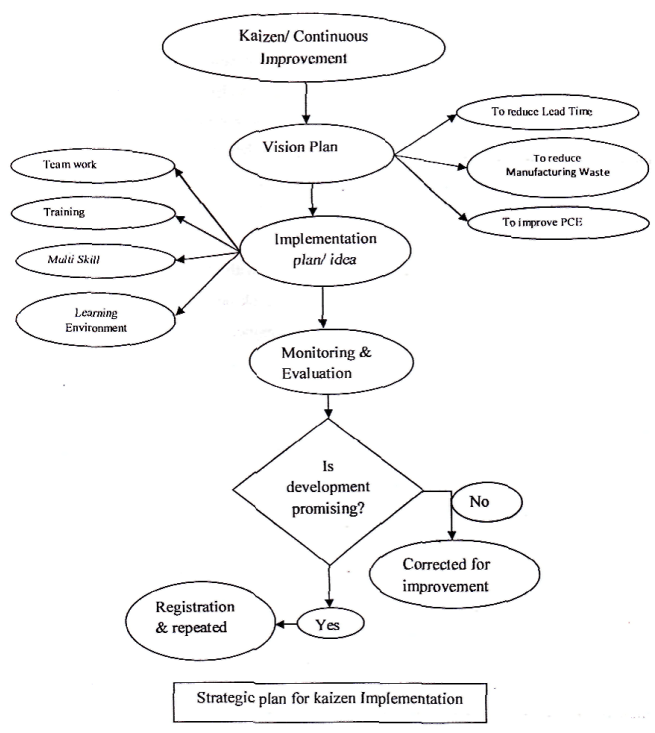

Figure 4. Strategic plan for kaizen implementation

problems and if this way is effective, it must be documented, and if not, attempts should continue towards an effective way beyond the elimination of problems for NVD activities.

\section{Just in Time (JIT)}

JIT is a Japanese management philosophy which has been applied in many Japanese manufacturing organizations since the early 1970s. It was first developed by Taiichi Ohno in the Toyota manufacturing plants as a means of meeting consumer demands within the minimum delays. The lean production firstly focuses on what is most commonly thought of as 'just in time' management which is considered as one of the basic principles of lean manufacturing. It is the idea of producing exactly what the customer wants, in the quantities they want, where they want it, when the customer wants it without being delayed or held upon inventory [28]. Inman and Bulfin [29] implied that JIT implementation provokes to reduce hurdles like long change over time; unleveled production schedules; highly variable production processes; large container sizes; severe bottlenecks and long lead time. 
A system where a customer initiates demand and the demand is then transmitted back from the final assembly all the way to raw material, thus "pulling" all requirements just when they are required [30, 31]. Actually, there are no unified steps towards the IIT implementation; because, the production phenomenon of different factories varies from each other. Moreover, the ability of the different techniques in different factories depends deeply on a specific manufacturing environment. However, benefits from these programs have often been limited because of unreliability or inflexibility [32]. Indeed, it is needed a reliable and flexible environment towards the JIT implementation. In the observed court shoe production line unwanted and unnecessary NVD waiting times were observed as very common between each two stages, especially in raw material inventory and finished goods inventory which could be reduced by JIT implementation. In order to implement JIT, some suggestions were proposed such as:

- Prepare the plant and its personnel for flexibility towards involving themselves within the JIT principles;

- $\quad$ Regarding personnel should be careful to the shortest lead time and high quality by concentrating maintenance and quality;

- $\quad$ Strive to produce with no waste by focusing on inventory control.

\section{THE FUTURE STATES OF COURT SHOE PRODUCTION LINE}

\section{Future VSM of Court Shoe Production Line}

Finally, the future VSM is constructed as shown in Figure 4 which reported a promising reduction in NVD time and lead time with improved PCE and up time. Table 5 outlines the value stream analysis report for the future state. It is found that after the implementation of lean tools PCE will be improved at internationally competitive level. Based on intense observation, brainstorming and previous regarding studies it is predicted that $50 \%$ NVD time of raw material inventory and shoe production steps could be reduced. The $80 \%$ NVD time of Sewing, pre-lasting, pot-lasting and finishing steps could be reduced after the implementation of lean tools. At future state, the total labor cost is found 17 , but it was 25 at present state i.e. after the implementation lean tools. At future state, the total labor is found 20 , but it was 36 at present state i.e. after the implementation of lean tools at least 15 labors could be the relief for another work. Then up time of sewing, lasting and finishing machine is found consecutively $96 \%$, $93 \%$, and $95 \%$ while it was consecutively $83 \%$, $64 \%$, and $76 \%$ at present state. At future state, it is also found the PCE will be $19.46 \%$ while it was $8.32 \%$ at present state. Therefore, at future state, the promising outcomes bring with the reduction of labor, NVD time and lead time, and improved up time and PCE.

Table 4: Future lead time analysis of Court Shoe Production Line

\begin{tabular}{ccc}
\hline Production stage & Value Added Time (Sec) & Non-Value Added Time (Sec) \\
\hline Receiving Inventory & 00 & $14400(50 \%)$ \\
Cutting & 600 & $600(50 \%)$ \\
Fitting \& Assembly & 1200 & $240(0 \%)$ \\
Sewing & 2297 & $140(80 \%)$ \\
Pre-lasting & 00 & $134(80 \%)$ \\
Post-lasting & 1650 & $274(80 \%)$ \\
Finishing & 1231 & $140(80 \%)$ \\
Shipping Inventory & 00 & $12960(70 \%)$ \\
Total & $6978(19.46 \%)$ & $28888(80.54 \%)$ \\
\hline
\end{tabular}

\section{Expected PCE at Future State}

At future state, it is expected that after the proper implementation of lean tools NVD time from $76889 \mathrm{sec}$ to $28888 \mathrm{sec}$, and thus the lead time would be reduced from $83867 \mathrm{sec}$ to 35866 sec. As earlier it is mentioned that PCE is measured as the percentage of the ratio of VD time and lead time and consequently at future state, the PCE is found $19.46 \%$ which is considered as the internationally competitive level $25 \%$ [17]. 


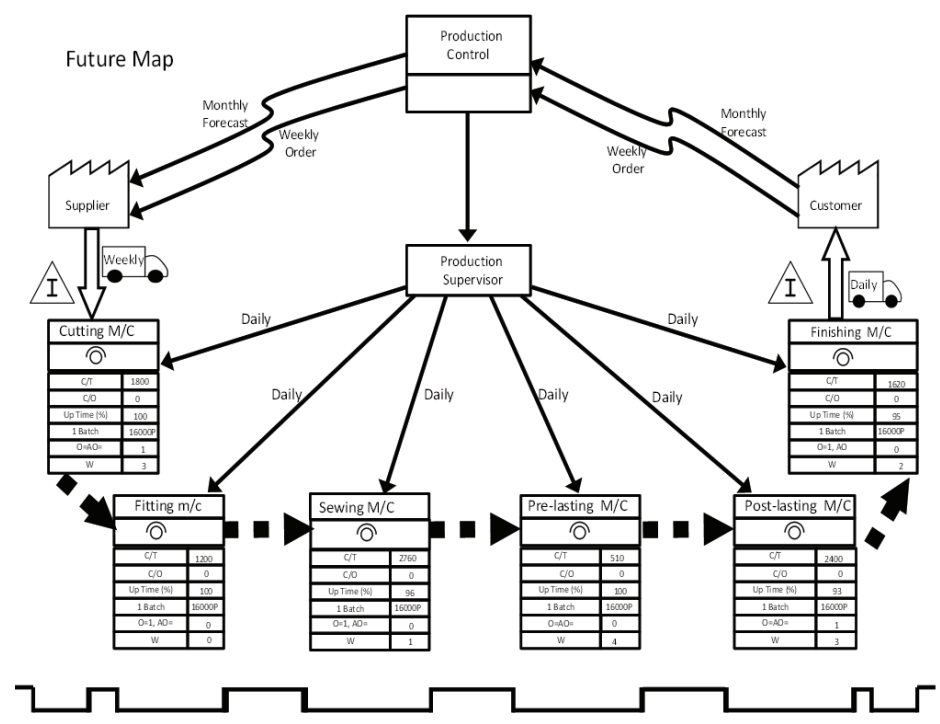

Figure 4. Future VSM of Court Shoe Production Line

\section{Expected Takt Time of Future State}

It is mentioned earlier that takt time is the heartbeat of a production process line. Takt time is the time that needs to produce a single unit of production. The lower it is, the faster the production is. Throughout this study, it was tried to reduce the takt time. At future state, after the adoption of lean tools, the takt time is found
$7.002 \mathrm{sec}$ while at present state production phenomenon it was found $7.20 \mathrm{sec}$.

\section{Achievement of Lean Tools Adoption}

A promising achievement is predicted with the reduced NVD time, lead time and takt time, and improved PCE. An improvement comparison between present and future state is given in the following Figure 5.

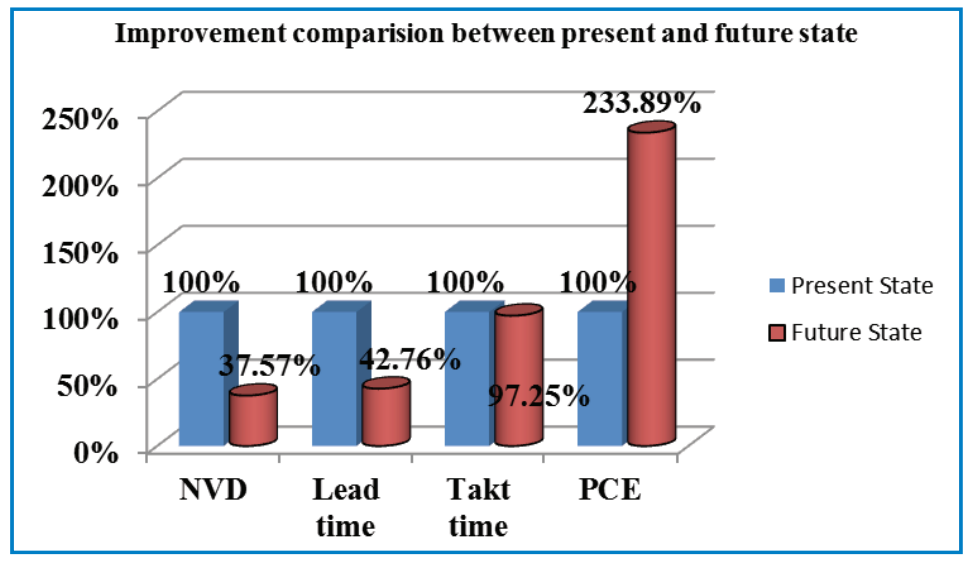

Figure 5. Improvement comparison between present and future state

At future state, it is seen that the NVD time will be reduced by $62.43 \%$, lead time will be reduced by $57.24 \%$, takt time will be reduced by $2.75 \%$ and PCE will be improved by $133.89 \%$. But all of these alluring achievements basically depend on the successful implementation of proposed lean tools. 


\section{TECHNOLOGY ASSESSMENTS}

\section{Assessment of Product Market Technology System Components Sophistication Range and} Innovation Scope of Studied Footwear Industry [33]

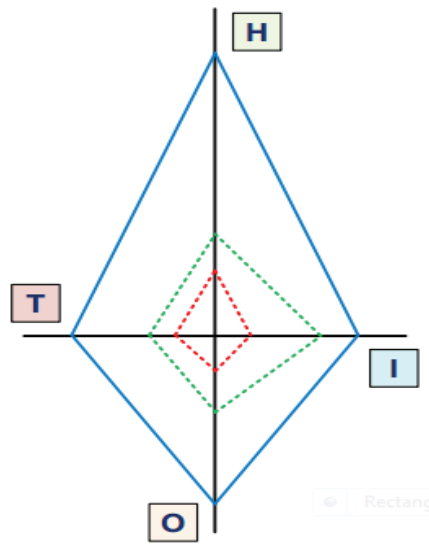

Figure 6. Technology components profile ( $\mathrm{T}$ - technoware, $\mathrm{H}$ - humanware,

I - infoware, O - orgaware). Ideal (Best) profile: Outer shape (blue),

Current profile: Middle shape (green), Minimum profile: Inner shape (red)

Below is the revised scoring table for assessing degree of sophistication of THIOs using a 9-point overlapping scoring scale with 10 for ideal best.

Table 5: Assessment of the degree of sophistication of THIOs

\begin{tabular}{|c|c|c|c|c|c|}
\hline $\begin{array}{c}\text { Technology } \\
\text { Components }\end{array}$ & $\begin{array}{c}\text { LOW Primitive } \\
\text { Score: } 1-2-3\end{array}$ & $\begin{array}{c}\text { MEDIUM } \\
\text { Traditional } \\
\text { Score: } 3-4-5\end{array}$ & $\begin{array}{c}\text { HIGH Modern } \\
\text { Score: } 5-6-7\end{array}$ & $\begin{array}{c}\text { TOP Emerging } \\
\text { Score: 7-8-9 }\end{array}$ & $\begin{array}{c}\text { IDEAL Best } \\
\text { Score: } 10\end{array}$ \\
\hline Technoware & Manual & Powered & Automatic & Programmable & Zero Deviation \\
\hline Humanware & Basic & Superior & Advanced & Extraordinary & Zero Error \\
\hline Infoware & General & Special & Unique & Frontier & Zero unknown \\
\hline Orgaware & Adhoc & Orderly & Managed & Optimized & Zero tolerance \\
\hline
\end{tabular}

Assessment of Product Market Value Using Integrated Business and Technology Strategies of Court Shoe [33]

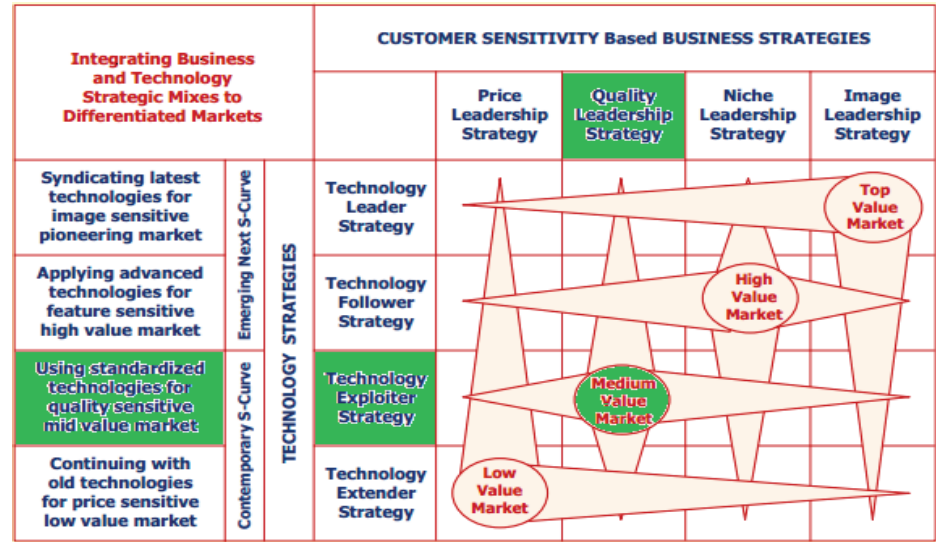

Figure 7. Integrated Business and Technology Strategies 


\section{CONCLUSIONS}

This study provides a case analysis of the improvement of a court shoe production line by reducing the lead time and improving the PCE by using of lean tools. It focuses the renovation of operations by eliminating the NVD time and lead time and improving the PCE through VSM, Pareto Analysis, 5S, and JIT. In a nutshell, it is inferred that a set of lean tools is an effective way to identify and eliminate the manufacturing NVD activities and time.

\section{REFERENCES}

1. Womack, J.P., Jones, D.T., Roos, D., The Machine that Changed the World, HarperCollins Publishers, New York, 1991.

2. Sayid Mia, M.A., Nur-E-Alam, M., Ahmad, F., Kamal Uddin, M., Footwear Industry in Bangladesh: Implementation of Six Sigma Methodology, Ind Eng Manage, 2017, 6, 211, https://doi.org/10.4172/21690316.1000211.

3. Hobbs, D.P., Lean Manufacturing Implementation: A Complete Execution Manual for any Size Manufacturer, J. Ross Publishing, Boca Raton, 2004.

4. Abdullah, F., Rajgopal, J., Lean Manufacturing in the Process Industry. Proceedings of the IIE Research Conference, CD-ROM, 2003, Portland, OR, IIE, Norcross, GA.

5. Ahmad, M., Dhafr, N., Benson, R., Burgess, B., Model for Establishing Theoretical Targets at the Shop Floor Level in Specialty Chemicals Manufacturing Organizations, Robot Comput Integr Manuf, 2005, 21, 4-5, 291-400.

6. Melton, T., The Benefits of Lean Manufacturing: What Lean Thinking Has to Offer the Process Industries, Chem Eng Res Des, 2005, 83, A6, 662-673.

7. Radnor, Z., Changing to a Lean Organisation: The Case of a Chemicals Company, International Journal of Manufacturing Technology and Management, 2000, 1, 4/5, 444-454.
8. Cook, R.C., Rogowski, R.A., Applying JIT Principles to Continuous Process Manufacturing Supply Chains, Production and Inventory Management Journal, 1996, First Quarter, 12-16.

9. Billesbach, J.T., Applying Lean Production Principles to a Process Facility, Production and Inventory Management Journal, 1994, Third Quarter, 40-44.

10.Abdullah, F., Rajgopal, J., Needy, K.L., A Taxonomy of the Process Industry with a View to Lean Manufacturing, Proceedings of the American Society for Engineering Management, Tampa, FL, 2002, 314-321.

11.Abdelmalek, F., Rajgopal, J., Needy, K.L., A Classification Model for the Process Industry to Guide the Implementation of Lean, Engineering Management Journal, 2006, 18, 1, 15-25.

12.Rajenthirakumar, D., Mohanram, P.V., Harikarthik, S.G., Process Cycle Efficiency Improvement Through Lean: A Case Study, International Journal of Lean Thinking, 2011, 2, 1, 46-58.

13.Womack, J.P., Daniel, T.J., Lean Thinking: Banish Waste and Create Wealth in your Corporation, New York, 1996, NY: Simon \& Schuster.

14.Young, H.K., Frank, T.A., Benefits, Obstacles, and Future of Six Sigma Approach, Technovation, 2006, 23, 708-715.

15.Pavlović, K., Božanić, V., Lean and Six Sigma Concepts, International Journal for Quality Research, 2012, 6, 1, 23-28.

16.Carlos, W.M., Optimization in Production Operations, Optimal "Lean Operations" in Manufacturing, (c) 2005-06 Ultramax Corporation, Oct. 5, 2006.

17.Zhen, Y., Food Safety and Lean Six Sigma Model, University of Central Missouri, Oct. 2011.

18. Sayid Mia, M.A., Nur-E-Alam, M., Lutfor Rahman, M., Kamal Uddin, M., Footwear Industry in Bangladesh: Reduction of Lead time by using Lean Tools, Journal of 
Environmental Science, Computer Science and Engineering \& Technology, Sec. C, 2017, 6, 3, 251-259, https://doi.org/10.24214/ jecet.C.6.3.25159.

19. Rother, M., Shook, J., Learning to See: Value Stream Mapping to Add Value and Eliminate MUDA, The Lean Enterprise Institute, Inc., Brookline, MA, 1999.

20.McDonald, T., Van Aken, E.M., Rentes, A.F., Utilizing Simulation to Enhance Value Stream Mapping: A Manufacturing Case Application, International Journal of Logistics: Research and Applications, 2002, 5, 2, 213-232.

21.Frandson, A., Berghede, K., Tommelein, I.D., Takt-Time Planning and the Last Planner, Production Planning and Control; Proceedings IGLC-22, June 2014, Oslo, Norway.

22.Pareto, V., Trattato di Sociologia Generale, Firenze, 1916, Engl.: The Mind and Society, Dover, 1935.

23.Kimber, R.J., Grenier, R.W., Heldt, J.J., Quality Management Handbook, Marcel Dekker, York, NY, 1997.

24.Dyche, J., The CRM Handbook: A Business Guide to Customer Relationship Management, Addison-Wesley, 2001.

25.Arthur, L.J., Rapid Evolutionary Development - Requirements, Prototyping \& Software Creation, John Wiley \& Sons, 1992.

26. Harry, M.J., Six Sigma: A Breakthrough Strategy for Profitability, Quality Progress, 1998, 31, 5, 60-64.
27.Tsuchiya, K., Soon, F., The Practice of Good Housekeeping (5S \& Kaizen), Singapore Productivity and Standards Board, 2008.

28. Monden, Y., Toyota Production System-An Integrated Approach to Just-In-Time, third ed. Engineering \& Management Press, Norcross, Georgia, 1998.

29.Inman, R., Bulfin, R.L., Sequencing of JIT Mixed Model Assembly Lines, Manag Sci, 1991, 37, 901-904.

30.Feld, W.M., Lean Manufacturing: Tools, Techniques, and How To Use Them, The St. Lucie Press, London, 2000.

31.Nahmias, S., Production and Operations Analysis, fourth ed. McGraw Hill, New York, 2001.

32.Tajiri, M., Gotoh, F., TPM Implementation: A Japanese Approach, McGrawHill Inc., New York, 1992.

33.Sharif, N.M., Fundamentals of Technological Innovation for Global Competition, Book of knowledge viewgraphs.

(C) 2017 by the author(s). Published by INCDTP-ICPI, Bucharest, RO. This is an open access article distributed under the terms and conditions of the Creative Commons Attribution license (http://creativecommons.org/licenses/ by/4.0/). 


\title{
CHARACTERISTICS OF POLYMER COMPOSITES BASED ON NATURAL RUBBER
}

\author{
Maria Daniela STELESCU1*, Elena MĂNĂILĂ², Maria SÖNMEZ ${ }^{1}$, Mihaela NIJUICĂ ${ }^{1}$ \\ ${ }^{1}$ National Research and Development Institute for Textiles and Leather (INCDTP), Division Leather and Footwear Research \\ Institute (ICPI), 93 Ion Minulescu St., Bucharest, Romania, dmstelescu@yahoo.com \\ ${ }^{2}$ National Institute for Laser, Plasma and Radiation Physics, Electron Accelerators Laboratory, 409 Atomistilor St., 077125, \\ Magurele, Romania
}

Received: 30.05.2017

Accepted: 01.08.2017

https://doi.org/10.24264/Ifj.17.3.4

\section{CHARACTERISTICS OF POLYMER COMPOSITES BASED ON NATURAL RUBBER}

ABSTRACT. This paper presents the obtaining and characterization of new types of polymeric composites based on natural rubber and plasticized starch, crosslinked using peroxide in the presence of a polyfunctional monomer - trimethylolpropane trimethacrylate. Composite variants containing $10 \mathrm{phr}, 20 \mathrm{phr}, 30 \mathrm{phr}, 40 \mathrm{phr}$ and $50 \mathrm{phr}$ starch, respectively were made. Starch was plasticized and then incorporated in natural rubber in the roll mill, and then other ingredients were added; the resulting mixtures were cured in an electrical press. The physicomechanical characteristics of resulting composites depends on the amount of plasticized starch added to the rubber mixture. The results of liquid action on composites show that it depends on the behaviour of mixture components in immersion media; thus, natural rubber is water resistant (variation of mass and volume in water has very low values) but not resistant to toluene (variation of mass and volume in toluene has high values); starch is hydrophilic - it absorbs water and, with the increased amount of starch in the mixtures, there is also an increase of mass and volume variation in water, but the values obtained are good, with mass and volume variation after $22 \mathrm{~h}$ of water immersion being below $8 \%$. In toluene, there is an improvement in the behaviour of composites containing plasticized starch compared to control ones (without plasticized starch). The new polymer composites can be used in various fields such as in the food or pharmaceutical areas that require compositions free of toxic ingredients.

KEY WORDS: polymer composites, natural rubber, starch, characteristics

\section{CARACTERISTICILE UNOR COMPOZITE POLIMERICE PE BAZĂ DE CAUCIUC NATURAL}

REZUMAT. Această lucrare prezintă obţinerea şi caracterizarea unor noi tipuri de compozite polimerice pe bază de cauciuc natural şi amidon plastifiat, reticulate utilizând peroxid în prezenţa unui monomer polifuncţional - trimetilolpropan trimetacrilat. Compozitele au fost realizate cu conţinut de amidon $10 \mathrm{phr}, 20 \mathrm{phr}, 30 \mathrm{phr}, 40 \mathrm{phr}$ şi respectiv 50 phr. Amidonul a fost plastifiat şi apoi încorporat în cauciucul natural pe valţ, după care s-au adăugat celelalte ingrediente; amestecurile obţinute au fost vulcanizate în presa electrică. Caracteristicile fizicomecanice ale compozitelor obţinute depind de cantitatea de amidon plastifiat adăugat amestecului de cauciuc. Rezultatele acţiunii lichidelor asupra compozitelor arată că aceasta depinde de comportarea componentelor amestecului în mediul de imersie; astfel, cauciucul natural este rezistent la apă (variaţia masei şi volumului în apă având valori foarte mici), dar nu este rezistent la toluen (variaţia masei şi volumului în toluen are valori mari); amidonul este hidrofil - absoarbe apa şi, odată cu creşterea cantităţii de amidon din amestecuri, are loc şi o creştere a variaţiei masei şi volumului în apă, însă valorile obţinute sunt bune, variaţia masei şi volumului după 22 h de imersie în apă fiind sub $8 \%$. În toluen se observă o îmbunătăţire a comportării compozitelor care conţin amidon plastifiat faţă de cele martor (fără amidon plastifiat). Noile compozite polimerice pot fi utilizate în diferite domenii cum ar fi în domeniul alimentar sau farmaceutic, unde este cerută o compoziţie lipsită de ingrediente toxice.

CUVINTE CHEIE: compozite polimerice, cauciuc natural, amidon, caracteristici

LES CARACTÉRISTIQUES DES COMPOSITIONS POLYMÉRIQUES EN CAOUTCHOUC NATUREL

RÉSUMÉ. Cet article présente la production et la caractérisation de nouveaux types de caoutchouc polymère à base de caoutchouc naturel et d'amidon plastifié, réticulés à l'aide de peroxyde en présence d'un monomère polyfonctionnel trimetacrylate de triméthylolpropane. Les composites ont été fabriqués contenant $10 \mathrm{phr}, 20 \mathrm{phr}, 30 \mathrm{phr}, 40 \mathrm{phr}$ et $50 \mathrm{phr}$ d'amidon respectivement. L'amidon a été plastifié puis incorporé dans le caoutchouc naturel sur le rouleau, après quoi les autres ingrédients ont été ajoutés; les mélanges obtenus ont été vulcanisés dans la presse électrique. Les caractéristiques physico-mécaniques des composites obtenues dépendent de la quantité d’amidon plastifié ajoutée au mélange de caoutchouc. Les résultats de l'action des liquides sur les composites montrent que cela dépend du comportement des composants du mélange dans le milieu d'immersion ; ainsi, le caoutchouc naturel est résistant à l'eau (variation de la masse et du volume dans l'eau a des valeurs très faibles) mais il n'est pas résistant au toluène (la variation de la masse et du volume dans le toluène est élevée) ; l'amidon a une nature hydrophile - il absorbe l'eau et avec l'augmentation de la quantité d’amidon dans les mélanges, il y a aussi une augmentation de la variation de la masse et du volume dans l'eau, mais les valeurs obtenues sont bonnes, la variation de la masse et du volume après 22 heures d'immersion dans l'eau est au-dessous de $8 \%$. Dans le toluène a été observée une amélioration du comportement des composites contenant de l'amidon plastifié. Les nouveaux composites polymériques peuvent être utilisés dans divers domaines, comme dans le domaine alimentaire ou pharmaceutique, où une composition exempte d'ingrédients toxiques est nécessaire.

MOTS CLÉS: composites polymériques, caoutchouc naturel, amidon, caractéristiques * Correspondence to: Maria Daniela STELESCU, National Research and Development Institute for Textiles and Leather (INCDTP), Division
Leather and Footwear Research Institute (ICPI), 93 Ion Minulescu St., Bucharest, Romania, e-mail: dmstelescu@yahoo.com 


\section{INTRODUCTION}

The oldest and most important elastomer that was the first model for attempts to synthesize rubber is natural rubber. This elastomer is obtained from a series of laticiferous plants, such as Hevea brasiliensi, Ficus elastica etc. Natural rubber is used mainly in the tire industry, and at least currently it cannot be fully replaced with any other type of synthetic rubber. Its long fatigue life and high strength makes it suitable for use up to approximately $100^{\circ} \mathrm{C}$, and can maintain flexibility down to $-60^{\circ} \mathrm{C}$ in combination with other substances. Other advantages include good creep and stress relaxation resistance and low cost. In terms of disadvantages, natural rubber has poor oil resistance and no resistance to oxygen and ozone, which can however be improved by compounding with specific chemicals [1].

Natural rubber (NR) as such has very limited applications. Basically all technical products made of rubber are compositions in which the elastomer matrix embeds: curing agents curing accelerators, ingredients for reinforcement and other components with the role of facilitating processability, increasing resistance to degradation, colouring the final product, etc. Reinforcing elastomers with certain ingredients called fillers is a process of high practical and technological importance. The most commonly used are active fillers such as silica and carbon black. Silica is known to have adverse effects on health: silicosis, cancer (Group 1 according to IARC - the International Agency for Research on Cancer), autoimmune diseases, tuberculosis, kidney disease, and so forth, and in 1995, the IARC rated carbon black as IARC classification $2 \mathrm{~B}$-possibly carcinogenic to humans and definitely carcinogenic to animals [2-4]. Carbon black is the most commonly used filler in NR compounds. For food applications, most furnace blacks are considered safe. According to existing food regulations, the type and the amount of carbon black is limited. According to FDA 177.2600 , the amount of carbon black may not exceed $50 \%$ by weight of the rubber product. In rubber products intended for use in contact with milk or edible oils, the total carbon black amount may not exceed $10 \%$. According to German BgVV
Recommendation XXI, the only carbon blacks that are allowed are those that fulfill the criteria for cleanliness according to German BGesundBL 15,268 (1972) [5]. For these reasons, efforts were made to replace them with other types of fillers. Currently the most viable way toward eco-friendly composites is the use of natural fibers as reinforcement. Natural fibers represent a traditional class of renewable materials which, nowadays, are experiencing a great revival [6, 7]. On the other hand, natural fibers exhibit many advantageous properties which promote the replacement of synthetic fibers in polymer composites. They are a low-density material yielding relatively lightweight composites with high specific properties and therefore natural fibers offer a high potential for an outstanding reinforcement in lightweight structures.

In this paper the active filler was replaced with starch in the form of plasticized starch. Starch is an organic substance found in the seeds, fruits and tubers of plants and is used in the food, chemical and other industries. Starch comes from renewable resources and has many advantages, such as: low price, availability, non-toxicity, and it is widely used in many areas (food, paper manufacturing, chemical industry, packaging material industry, etc.) [8]. Starch can be altered by plasticization to improve its processability and other properties required for certain applications. Plasticizers bind macromolecules to high molecular mass compounds, thus leading to better processability. In the case of mixtures based on starch, tensile strength and flow properties may significantly improve through their conversion to plasticized starch using compounds such as water, glycerine or formamide, as the latter lead to more stable properties [8-9]. In this paper, starch was plasticized using water and glycerine.

The most important step of the technological process for developing rubber products is curing. Out of the several possibilities to crosslink natural rubber, the best known method is vulcanization with sulphur and curing accelerators. This occurs by ionic mechanism and leads to the formation of sulphur bridges between (C-Sx-C) macromolecules or cyclic combination of sulphur. Physical-mechanical properties of samples containing $\mathrm{C}-\mathrm{S} \mathrm{X}-\mathrm{C}$ crosslinking bridges 
exhibit better tensile strength values than those containing $\mathrm{C}-\mathrm{C}$ bonds. Although vulcanization with sulphur and vulcanization accelerators leads to obtaining products with better characteristics, it also has disadvantages, such as the fact that during the process of vulcanization nitrosamines (carcinogen products) are formed and the obtained end products are toxic, contain heavy metals $(Z n)$, have an unpleasant odor and exudate $[10,11]$. For these reasons, efforts are made internationally to replace sulfur and curing accelerators vulcanization systems. In this paper, crosslinking is done using peroxide in the presence of vulcanization co-agent. The use of organic peroxides is the only vulcanization method that can compete with accelerated sulphur cure, with respect to vulcanization rate. Peroxide vulcanisation leads to a rubber network in which the polymer chains are linked to each other by very stable covalent carboncarbon bonds. Peroxide cured vulcanisates have therefore good high temperature properties, like heat ageing and compression set, compared to sulphur cured articles [12-14].

This paper presents the process of obtaining and characterizing a new type of polymeric composite based on natural rubber and plasticized starch as filler, crosslinked using peroxide in the presence of a polyfunctional monomer - trimethylolpropane trimethacrylate. It also studies the influence of plasticized starch amount on the physical-mechanical properties and behaviour in aqueous and toluene environment.

\section{EXPERIMENTAL}

\section{Materials}

The following materials were used for rubber mixtures:

- Natural rubber (NR) for pharmaceutical use, Crep from Sangtvon Rubber Ltd, in the form of white rubber sheets, Mooney viscosity 67.64 $\mathrm{ML}\left(1^{\prime}+4^{\prime}\right) 100^{\circ} \mathrm{C}$, volatile matter content of $0.5 \%$, nitrogen content $0.45 \%$, ash content of $0.25 \%$, impurity content of $0.026 \%$;

- Starch - produced by Lach-Ner - soluble potato starch (water insoluble substances $0.28 \%$; loss on drying $16.9 \%$, easily biodegradable: $\mathrm{BOD}_{5}-$ $0.6 \mathrm{~g} / \mathrm{g}$ - and COD - $1.2 \mathrm{mg} / \mathrm{g}$ );

- Glycerine from SC Chimreactiv SRL (free acidity $0.02 \%$, density $1.26 \mathrm{~g} /$ $\mathrm{cm}^{3}$, purity $\left.99.5 \%\right)$;

- $\quad$ Richon IPPD antioxidant (4010 NA) $\mathrm{N}$-isopropyl - N-phenyl - phenylene diamine, $98 \%$ purity, molecular mass: 493.6374;

The following materials were used for crosslinking blends: Perkadox 40 benzoyl peroxide (density $160 \mathrm{~g} / \mathrm{cm}^{3}, 3.8 \%$ active oxygen content, $40 \%$ peroxide content, $\mathrm{pH} 7$ ) and Luvomaxx TMPT DL 75 (TMPT) trimethylolpropane trimethacrylate polyfunctional monomer (22\% ash, pH 9.2, density $1.36 \mathrm{~g} / \mathrm{cm}^{3}, 75 \pm 3 \%$ active ingredient).

\section{Plasticizing Starch}

Starch (50\%), water (20\%) and then glycerine $(30 \%)$ are mixed at $70^{\circ} \mathrm{C}$ for $15 \mathrm{~min}$ at $50-100 \mathrm{rpm}$ until a homogenous mixture is obtained. It is left for $1 \mathrm{~h}$ at room temperature, then in the oven for $22 \mathrm{~h}$ at $80^{\circ} \mathrm{C}$ and then for $2 \mathrm{~h}$ at $110^{\circ} \mathrm{C}$. It is left for $16 \mathrm{~h}$ in a dry place.

\section{Obtaining Polymer Composites}

The process of obtaining composite materials based on natural rubber and plasticized starch comprises: operations of characterizing raw materials, dosing raw materials and obtaining the composite by roller mixing.

Polymer composites based on natural rubber and plasticized starch consist of a rubber mixture whose composition is shown in Table 1. Mixtures were crosslinked with peroxide in the presence of a curing co-agent/polyfunctional monomer. The roller mixer working method is presented in Table 2. Roller mixer working parameters are: working temperature is kept below $60^{\circ} \mathrm{C}$, and friction is $1: 1,1$.

The products obtained as rubber mixtures in the form of sheets. These sheets were cured using molds and vulcanization press in order to obtain rubber plates with the sizes of $150 \mathrm{~mm} x$ $150 \mathrm{~mm} \times 2 \mathrm{~mm}$ required for die punching test specimens for the characterization of polymer composites. 
Table 1: Formulations

\begin{tabular}{lcccccc}
\hline Mixture symbol & $\begin{array}{l}\text { NR-0 } \\
(\mathrm{phr})\end{array}$ & $\begin{array}{l}\text { NR-10 } \\
(\mathrm{phr})\end{array}$ & $\begin{array}{l}\text { NR-20 } \\
(\mathrm{phr})\end{array}$ & $\begin{array}{l}\text { NR-30 } \\
(\mathrm{phr})\end{array}$ & $\begin{array}{l}\text { NR-40 } \\
(\mathrm{phr})\end{array}$ & $\begin{array}{l}\text { NR-50 } \\
(\mathrm{phr})\end{array}$ \\
\hline Natural rubber & 100 & 100 & 100 & 100 & 100 & 100 \\
Starch & - & $\mathbf{1 0}$ & $\mathbf{2 0}$ & $\mathbf{3 0}$ & $\mathbf{4 0}$ & $\mathbf{5 0}$ \\
Glycerine & - & 6 & 12 & 18 & 24 & 30 \\
Peroxide & 8 & 8 & 8 & 8 & 8 & 8 \\
TMPT & 3 & 3 & 3 & 3 & 3 & 3 \\
Antioxidant 4010 & 1 & 1 & 1 & 1 & 1 & 1 \\
\hline
\end{tabular}

Table 2: Roller mixer working method

\begin{tabular}{|c|c|}
\hline Order of adding ingredients & Time \\
\hline (1) Rubber is mixed in the roller mixer & ca. $2^{\prime}$ \\
\hline + (2) plasticized starch and glycerine & ca. $5^{\prime}-30^{\prime}$ \\
\hline$+(5)$ antioxidant & ca. $1^{\prime}$ \\
\hline + (3) + (4) peroxide and TMPT & ca. $1^{\prime}$ \\
\hline Homogenisation & ca. $2^{\prime}$ \\
\hline Removing the mixture from the roller & ca. $1^{\prime}$ \\
\hline & $12-37^{\prime}$ \\
\hline
\end{tabular}

\section{Preparation of Sample}

Test specimen sheets of all compounds were produced using compression moulding. The temperature of the compression moulding machine was kept constant at $160^{\circ} \mathrm{C}$, for $20^{\prime}$ at a pressure of $300 \mathrm{kN}$. Cooling time $10^{\prime}$ at $25^{\circ} \mathrm{C}$ and $300 \mathrm{kN}$.

\section{Laboratory Tests}

\section{Physical-Mechanical Characteristics}

Tensile strength and tearing strength tests were carried out with a Schopper strength tester with testing speed $460 \mathrm{~mm} / \mathrm{min}$, using dumbbell shaped specimens according to ISO 37/2012, and angular test pieces (Type II) according to EN 12771/2003, respectively. Hardness was measured by using a hardness tester according to ISO 7619-1/2011 using 6-mm thick samples. Elasticity (rebound resilience) was evaluated with a Schob test machine using 6-mm thick samples, according to ISO 4662/2009.

\section{Determination of Liquid Action}

Determinations were performed according to ISO $1817 / 2015$ and the action of the following liquids was tested: water and toluene. The test pieces of known weight, $m_{\sigma}$ were immersed in various solvents in diffusion test bottles and kept at room temperature for 22 hours. After immersion the samples were taken out from the solvents and the wet surfaces were quickly dried using a tissue paper and re-weighted, $m_{i}$.

To calculate the percentage change in mass $\Delta m_{100}$ the following formula was used (1):

$$
\Delta m_{100}=\frac{m_{i}-m_{0}}{m_{0}} \times 100
$$

where $m_{0}$ is the initial mass of the test piece and $m_{\mathrm{i}}$ is the mass of the test piece after immersion. 
To calculate the percentage change in volume $\Delta V_{100}$ the following formula was used (2):

$$
\Delta V_{100}=\left(\frac{m_{i}-m_{i, w}+m_{s, w}}{m_{0}-m_{0, w}+m_{s, w}}-1\right) x 100
$$

where:

- $m_{0, w}$ is the initial mass of the test piece (plus sinker if used) in water;

- $m_{i, w}$ is the mass of the test piece (plus sinker if used) after immersion in water;

- $m_{s, w}$ is the mass of the sinker, if used, in water.

The result was reported as the median value for the three test pieces.

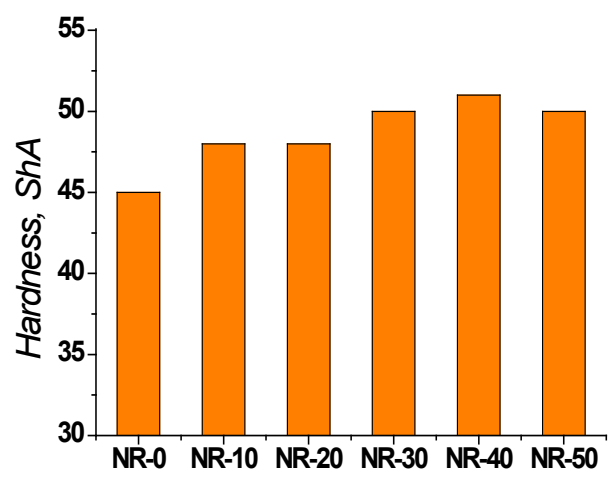

Figure 1. Hardness variation depending on the amount of plasticized starch introduced in the mixture

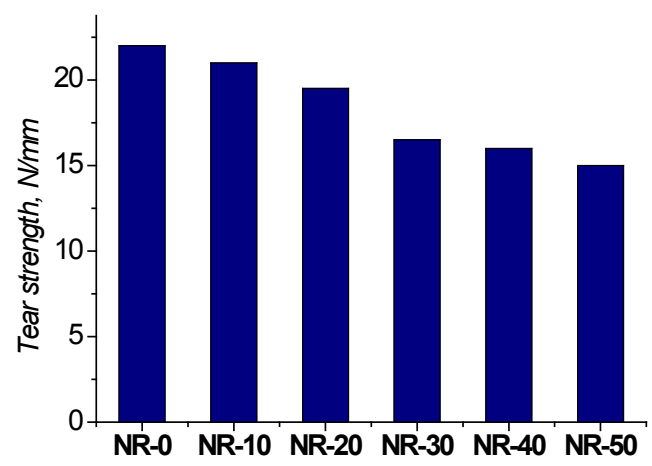

Figure 3. Tear strength variation depending on the amount of plasticized starch introduced in the mixture

\section{RESULTS AND DISCUSSIONS}

\section{Physical-Mechanical Characteristics}

The influence of the plasticized starch amount on the physical-mechanical characteristics of mixtures is illustrated in Figures 1-5. Analyzing the physical-mechanical characteristics of mixtures based on natural rubber and plasticized starch, it can be noticed that when increasing the amount of starch in the mixtures: (a) hardness (Figure 1) increases indicating that starch leads to NR reinforcement, (b) elasticity (Figure 2) decreased as a result of lowering the amount of natural rubber in the mixtures and reinforcing the mixtures; (c) tear strength (Figure 3) decreased, and tensile strength (Figure 4) improved, however it shows a

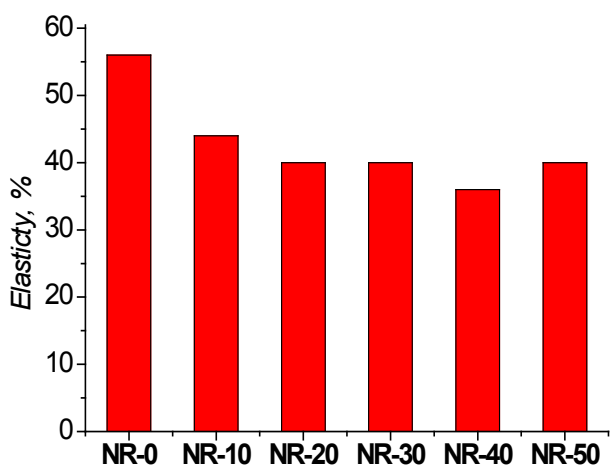

Figure 2. Elasticity variation depending on the amount of plasticized starch introduced in the mixture

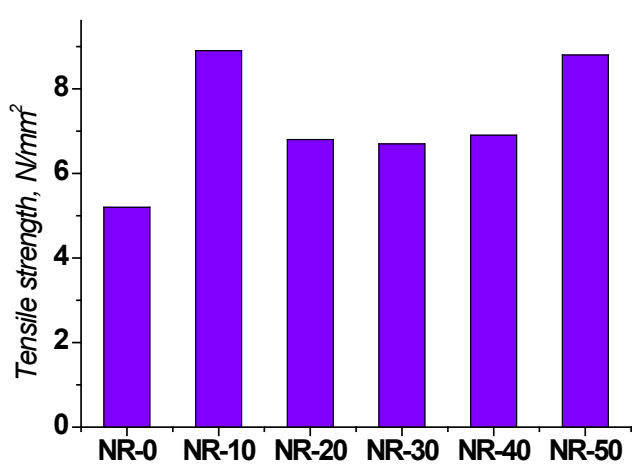

Figure 4. Tensile strength variation depending on the amount of plasticized starch introduced in the mixture 


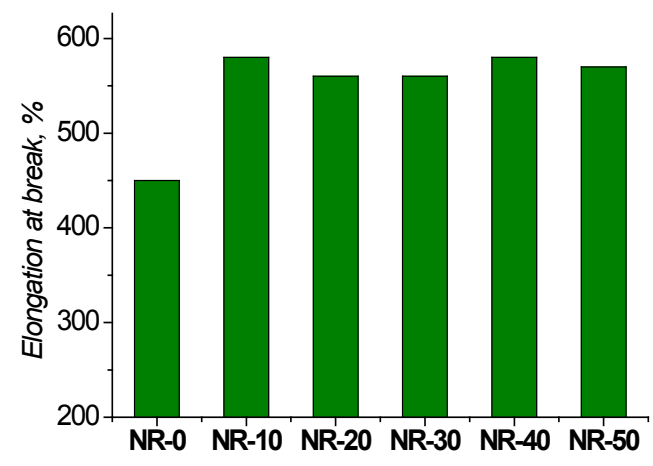

Figure 5. Elongation at break variation depending on the amount of plasticized starch introduced in the mixture

non-uniform variation to increasing the amount of starch; (d) elongation at break (Figure 5) shows a non-uniform increase with the increase of plasticized starch amount. The data shows that plasticized starch may replace active fillers such as carbon black or precipitated silica which are harmful and may cause occupational illnesses to employees in the rubber processing industry.

\section{Action of Liquids on Composites}

The results of liquid action on composites are presented in Figures 6-7. The data show

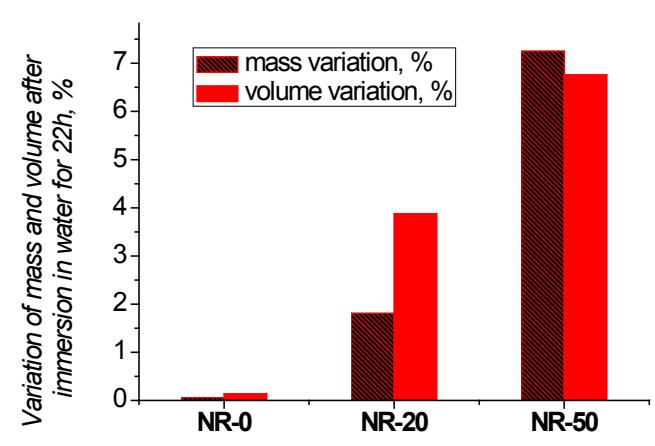

Figure 6. Variation of mass and volume after immersion in water for $22 \mathrm{~h}$

\section{CONCLUSIONS}

A new type of polymeric composites based on natural rubber and plasticized starch as filler was obtained and characterized, crosslinked using peroxide in the presence of that it depends on the behaviour of mixture components in immersion media; thus, natural rubber is water resistant (variation of mass and volume in water has very low values) but not resistant to toluene (variation of mass and volume in toluene has high values); starch has a hydrophilic nature - it absorbs water and, with the increased amount of starch in the mixtures, there is also an increase of mass and volume variation in water.

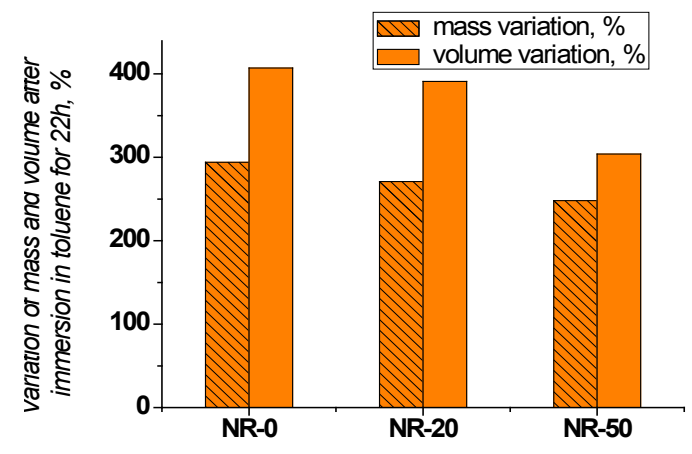

Figure 7. Variation of mass and volume after immersion in toluene for $22 \mathrm{~h}$

trimethylolpropane trimethacrylate. These composites have good physical-mechanical characteristics, indicating that plasticized starch may successfully replace inorganic fillers in rubber mixtures, which are harmful and may cause occupational illnesses to employees in the 
rubber processing industry. The results of liquid action on composites show that it depends on the behaviour of mixture components in immersion media; thus, natural rubber is water resistant (variation of mass and volume in water has very low values) but not resistant to toluene (variation of mass and volume in toluene has high values); starch has a hydrophilic nature - it absorbs water and, with the increased amount of starch in the mixtures, there is also an increase of mass and volume variation in water, however the values obtained are good, mass and volume variation after $22 \mathrm{~h}$ of immersion being below $8 \%$. In toluene, an improvement is seen in the behaviour of composites containing plasticized starch compared to control samples.

The new polymer composites may be used in various areas such as the food or pharmaceutical industry that requires compositions free of toxic ingredients.

\section{Acknowledgements}

This research was financed through Nucleu Program 2016-2017, project PN 163401 01: “Development of biodegradable nanocomposites based on natural rubber, starch and OMMT with applications in the food and pharmaceutical industries" by Romanian Ministry of Research and Innovation.

\section{REFERENCES}

1. Manaila, E., Craciun, G., Stelescu, M.D., Ighigeanu, D., Ficai, M., Radiation Vulcanization of Natural Rubber with Polyfunctional Monomers, Polym Bull, 2014, 71, 57-82.

2. IARC Working Group on the Evaluation of Carcinogenic Risks to Humans, Silica, Some Silicates, Coal Dust and Para-Aramid Fibrils, IARC Monographs on the Evaluation of Carcinogenic Risks to Humans, vol. 68, World Health Organization, Lyon, 1997, http:// monographs.iarc.fr/ENG/ Monographs/ vol68/index.php. Accessed 18 Sep 2014.
3. Beliczky, L.S., Fajen, J., Rubber Industry, in J.M. Stellman (Ed.), Encyclopaedia of Occupational Health and Safety, chapter 80, International Labor Office, Geneva, Switzerland, 4th edition, 1998.

4. Stelescu, M.D., Manaila, E., Craciun, G., Dumitrascu, M., New Green Polymeric Composites Based on Hemp and Natural Rubber Processed by Electron Beam Irradiation, Scientific World J, Volume 2014, Article ID 684047, http://dx.doi. org/10.1155/2014/684047.

5. De Coster, N., Magg, H., Leverkusen, NBR in Contact with Food, Potable Water, Pharmaceutical and Cosmetic Applications, KGK Kautschuk Gummi Kunststoffe, 56. Jahrgang, Nr. 7-8, 2003.

6. Manaila E., Stelescu, M.D., Doroftei, F., Polymeric Composites Based On Natural Rubber And Hemp Fibers, Iran Polym J, 2015, 24, 2, 135-148.

7. Cristaldi, G., Latteri, A., Recca, G., Cicala, G., Composites Based on Natural Fibre Fabrics, in P.D. Dubrovski (Ed.), Woven Fabric Engineering, Sciyo, Rijeka, Croatia, Published Online 18 August, 2010, 318-342, www. Intechopen.Com, accessed 2 June 2014.

8. Wu, Y.-P., Qi, Q., Liang, G.-H., Zhang, L.-Q., A Strategy to Prepare High Performance Starch/ Rubber Composites: In situ Modification during Latex Compounding Process, Carbohydr Polym, 2006, 65, 109-113.

9. Shey, J., Imam, S.H., Glenn, G.M., Orts, W.J., Properties of Baked Starch Foam with Natural Rubber Latex, Ind Crops Prod, 2006, 24, 1, 3440.

10. Stelescu, M.D., Manaila, E., Craciun, G., Vulcanization of Ethylene-PropyleneTerpolymer-based Rubber Mixtures by Radiation Processing, J Appl Polym Sci, 2012, 128, 2325-2336. 
11. Gonzalez, L., Rodriguez, A., MarcosFernandez, A., Chamorro, C., A New Interpretation of the Crosslinking Mechanism of NR with Dicumyl Peroxide, Kautsch Gummi Kunstst, 1998, 51, 2, 83-87.

12. Gonzalez, L., Rodriguez, A., Valentin, J.L., Marcos-Fernandez, A., Posadas, P., Conventional and Efficient Crosslinking of Natural Rubber, Kautsch Gummi Kunstst, 2005, 58, 638-643.

13. Ikarashi, Y., Toyoda, K., Ohasawa, N., Uchima, T., Tsuchiya, T., Kaniwa, M.A., Sato, M., Takahashi, M., Nakamura, A., Comparative Studies by Cell Culture and in vivo Implantation Test on the Toxicity of Natural Rubber Latex Materials, J Biomed Mater Res, 1992, 26, 3, 339-356.
14. Dluzneski, P.R., Peroxide Vulcanization of Elastomers, Rubber Chem Technol, 2001, 74, 3, 451-492.

(C) 2017 by the author(s). Published by INCDTP-ICPI, Bucharest, RO. This is an open access article distributed under the terms and conditions of the Creative Commons Attribution license (http://creativecommons.org/licenses/ by/4.0/). 


\title{
A STUDY ON WATER VAPOUR PERMEABILITY WITH INCREASED FUNCTIONAL PROPERTIES OF UPPER LEATHERS
}

\author{
Victor JOHN SUNDAR*, Chellappa MURALIDHARAN \\ Leather Process Technology Division, Adyar, Chennai - 600 020, India \\ Accepted: 18.05.2017 \\ https://doi.org/10.24264/Ifj.17.3.5
}

Received: 20.04.2017

\section{A STUDY ON WATER VAPOUR PERMEABILITY WITH INCREASED FUNCTIONAL PROPERTIES OF UPPER LEATHERS}

ABSTRACT. Water vapour permeability is one of the most important physical properties of leathers, which impacts the essential functional properties such as the breathability and the comfort of leather products. With growing stringent requirements for sports footwear this property gains added significance. In this work an attempt has been made to enhance the water vapour permeability for upper leathers by opening up the fibre structure and designing suitable tanning and post tanning processes. The objective of improving water vapor permeability through enzymatic and chemical methods has been achieved without affecting other mechanical properties of leathers. Thermoporometry results too confirmed the water vapour permeability was improved positively with enzymatic and chemical treated leathers. The major finding is the differences in water vapour permeability between crust and finished leathers were minimal.

KEY WORDS: leather, water vapour permeability, footwear

\section{STUDIU PRIVIND EFECTUL PERMEABILITĂTII LA VAPORI DE APĂ ASUPRA ÎMBUNĂTĂTIRII PROPRIETĂTILOR FUNCTIONALE ALE PIEILOR PENTRU FETE ÎNCĂLTĂMINTE}

REZUMAT. Permeabilitatea la vaporii de apă este una dintre cele mai importante proprietăţi fizice ale pieilor, care influenţează proprietăţi funcţionale esenţiale, cum ar fi respiraţia şi confortul produselor din piele. Având în vedere cerinţele din ce în ce mai stringente pentru încălţămintea sportivă, această proprietate capătă o importanţă şi mai mare. În această lucrare s-a încercat creşterea permeabilităţii la vaporii de apă pentru pielea destinată feţelor de încălţăminte prin deschiderea structurii fibrelor şi prin conceperea unor procedee adecvate de tăbăcire şi post-tăbăcire. Obiectivul de a îmbunătăţi permeabilitatea la vaporii de apă prin metode enzimatice şi chimice a fost realizat fără a afecta alte proprietăţi mecanice ale pieilor. Rezultatele termoporometriei confirmă că permeabilitatea la vaporii de apă a fost îmbunătăţită în cazul pieilor tratate enzimatic şi chimic. Principala constatare este că diferenţele de permeabilitate la vaporii de apă dintre pielea crust şi cea finită au fost minime.

CUVINTE CHEIE: piele, permeabilitate la vapori de apă, încălţăminte

\section{UNE ÉTUDE SUR LA PERMEABILITÉ À LA VAPEUR D’EAU POUR AUGMENTER LES PROPRIÉTÉS FONCTIONNELLES DES TIGES CUIR}

RÉSUMÉ. La perméabilité à la vapeur d'eau est l'une des propriétés physiques les plus importantes des cuirs, qui affecte les propriétés fonctionnelles essentielles telles que la respirabilité et le confort des produits en cuir. Compte tenu des exigences de chaussures de sport de plus en plus strictes, cette propriété acquiert encore plus d'importance. Dans cet article, on a essayé l'augmentation de la perméabilité à la vapeur d'eau du cuir pour tiges chaussures par l'ouverture de la structure fibreuse et en développant des méthodes appropriées de tannage et de post-tannage. L'objectif d'améliorer la perméabilité à la vapeur d'eau par des procédés chimiques et enzymatiques a été atteint sans affecter les autres propriétés mécaniques du cuir. Les résultats de la thermoporométrie confirment que la perméabilité à la vapeur d'eau a été améliorée dans le cas des cuirs au traitement enzymatique et chimique. La principale conclusion est que les différences de perméabilité à la vapeur d'eau entre le cuir en croûte et le cuir fini ont été minimes.

MOTS CLÉS: cuir, perméabilité à la vapeur d'eau, chaussures.

\section{INTRODUCTION}

Leather is an unique material that has the ability to absorb water vapor, transmit through its cross section and permeate into the atmosphere. This unique characteristic of leather offers comfort to the wearer of shoes in hot and humid conditions. In addition upper leathers should possess comfort properties, strength properties, functional properties and aesthetic properties.
Under normal conditions, 5 gms/hour sweat is produced by a human when the temperature condition is between 30 and $35^{\circ} \mathrm{C}$. Under industrial working condition, the sweat produced by a human foot is around $10 \mathrm{gms} /$ hour. Leather footwear has the ability to absorb the sweat produced and transmit to the upper part of the leather through wicking process which is known as water vapour permeability or water vapour

\footnotetext{
* Correspondence to: Victor JOHN SUNDAR, Leather Process Technology Division, CSIR-Central Leather Research Institute, Adyar, Chennai-600020, Tamil Nadu, India, e-mail: johnsundar70@yahoo.co.uk
} 
transmission [1]. Water vapour permeability is the ability of leathers allowing water vapour to transfer through from higher humid condition to lower humid condition [2]. This characteristic mainly depends on the porosity characteristic of leather. The ability to transmit water vapour is one of the important properties of leather that makes it most desirable for shoe making.

There are plenty of capillaries among collagen fibres in leathers as well as a lot of hydrophilic groups on the collagen chains. They may endow leathers with good water vapour permeability, compared with other synthetic materials [3]. Water vapour permeability is the volume of permeating water vapour in unit time and unit area, its unit is $\mathrm{mg} / 10 \mathrm{~cm}^{2} \mathrm{~h}$. The property depends upon a number of factors including porosity, thickness of leather, grease content and the relative humidity and temperature of the atmosphere [4]. It is greatly reduced by the presence of the natural glyceride greases. The solution is to remove natural fat during degreasing process with chemicals which do not affect the water absorbency. The finish on the grain layer also has an influence on water vapour transmission. Although leathers have a certain degree of water vapour permeability, improved water vapour permeability is required for special purposes such as application in sports shoes. Hence a study is undertaken to improve water vapour permeability without affecting those strength properties required for upper leather $[5,6]$.

\section{MATERIALS AND METHODS}

\section{Materials}

Fresh wet salted goat skins (24"$\left.28^{\prime \prime}\right)$ without any hair slip were chosen for experiments. Commercial grade protease and lipase (with activity in the range of $80-100$ TU), urea and acetic acid were chosen for experiments.

\section{Processing Methods}

Two pronged approach has been attempted to achieve enhanced water vapour permeability of skins viz., extensive enzymatic treatment during pre-tanning and treatment with lyotropic agents after chrome tanning.

\section{Liming}

The purpose of liming is to remove hair, epidermis, natural fats and greases, interfibrillary proteins, to swell and split up the fibre bundles, to soften the collagen fiber lattice and make the final leather soft and pliable. Conventional sulphide unhairing methods often do not yield clean pelt leaving residual scud which hinders the permeation. But enzymatic unhairing using proteolytic enzymes helps in complete removal of hair from its follicle yielding clean pores so that permeability of water vapor is enhanced. Enzymes are biocatalyst, hence they are specific in their action and they act specifically at the hair follicle and remove hair in shorter duration [7-9].

\section{Bating}

The objective of bating the delimed pelts with proteolytic enzymes is to remove non leather making substance and to make the grain surface clean, smooth and fine. The purpose is to remove the hair roots, break down of the non-structural proteins and to get clean pelt. The efficiency of bating depends on temperature, concentration, $\mathrm{pH}$ and duration. The experiment is carried out with varying concentrations of enzyme. The physical tests were performed at crust and finished leather stages.

\section{Degreasing}

Degreasing is the process of removing natural fat present in between the collagen fibers. If this fat is not removed completely, it affects the water vapour transmission in the final leather apart from forming fat spew. Conventionally huge amounts of solvents and surfactants are used for this challenging process. During the present study, lipase was used which acts specifically on lipids and frees the pores from blockage which enhances the permeation of water vapor.

\section{Treatment of Chrome Tanned Leathers}

When chrome tanned leathers are treated with lyotropic agents like urea $\left(\mathrm{CH}_{4} \mathrm{~N}_{2} \mathrm{O}\right)$, and acetic acid $\left(\mathrm{CH}_{3} \mathrm{COOH}\right)$ hydrogen bonds are broken and cementing substances held by the fiber bundles are removed. The quantities of the chemicals were optimized after several experiments. 


\section{Determination of Water Vapour Permeability}

Leather sample test specimens were taken from the official sampling position (ISO 2418) and were conditioned for 48 hours at $20^{\circ} \mathrm{C} \pm 2{ }^{\circ} \mathrm{C}$ and $65 \pm 2 \% \mathrm{RH}$ (ISO 2419). The leather sample under test is sealed on the mouth of a desiccant (dry silica gel) filled jar that provides a less humid gradient across the test sample and outside. The test jars sealed with dry silica gel held in a vertical wheel which rotates during the test. A large fan is also incorporated within the equipment, and this rotates in the opposite direction to the sample wheel. This creates air turbulence over the samples sealed in the mouth of the jar, thus removing the layer of still air. The sealed jars are weighed before and after test, and the increase in weight of desiccant is used to calculate the WVP of the sample, usually expressed as milligrams of water vapor per square centimeter per hour. The water vapour permeability tests were done for dyed crust leathers and for finished leathers [10-12].

\section{Determination of Tensile Strength and Elongation at Break}

The tensile strength, \% elongation, tear strength and grain crack strength were measured as per official procedures (SLTC Methods, 1965). The test specimens were conditioned for 48 hours at $20^{\circ} \mathrm{C} \pm 2^{\circ} \mathrm{C}$ and $65 \pm 2 \% \mathrm{RH}$. Strength characteristics of the leathers were tested for tensile strength and tongue tear strength tests in a Universal Instron testing machine (Instron 4501, England). A crosshead speed of $100 \pm 20$ $\mathrm{mm} / \mathrm{min}$ was used and the distance between the supports was $40 \mathrm{~mm}$. A load was applied to the center of the samples until fracture occurred and the fracture load was recorded.

The crust leathers were also tested for grain crack and grain burst using a lastometer (SATRA 1992). The test specimen was tightly clamped between the circular rings facing grain side upwards and the machine started by forcing the plunger at the rate of $0.2 \pm 0.05 \mathrm{~mm} / \mathrm{s}$. The surface of the specimen was continuously observed at the center for initial crack on the grain and the maximum distance and force were recorded.

\section{Capillary Flow Porometry Analysis}

PMI capillary flow porometer was used in this study to analyze the pore size and its distribution. The experimental and conventionally processed leather samples from different locations of crust leathers were cut into $20 \mathrm{~mm}$ diameter and the thickness was noted. Calwick with a defined surface tension of 15.9 dynes $\mathrm{cm}^{-1}$ was used as wetting liquid for porometry measurements. In this technique, at first a non-reacting gas was sent through a dry sample. Second, the same sample was wetted with liquid of known surface tension, through which the above mentioned gas was sent. The changes in flow rate were measured as a function of pressure for both dry and wet processes. The samples which had better water vapour permeability are chosen for wet and dry profiles (pressure vs. gas flow rate) which are measured for porosity.

\section{Scanning Electron Microscope}

The fibre structure of the control and experimental leathers have been studied using SEM analysis. Leather samples were coated with gold using an Edwards E 306 Sputter coater and analyzed by a Cambridge stereoscan S 150 scanning electron microscope.

\section{RESULTS AND DISCUSSIONS}

Water vapour permeability of control and experimental crust and finished leathers are shown in Table 1 and Table 2. According to the results, the leathers undergone enzymatic dehairing and bating processes have improved water vapour permeability compared to conventionally processed leathers. The better opening up of fibre structure by proteases may be the reason for more water vapour transmission without affecting strength properties. The best degreasing effect was obtained with the use of lipase alone. The effective saponification of natural greases increased the water vapor permeability compared to conventional surfactant based degreasing. When chrome tanned leathers were treated with unionized acetic acid, it attaches as a molecule to the collagen chains breaking the hydrogen bonds present in the collagen and thus resulting in fibre splitting. The treatment of skin matrix by urea 
has been proved to affect mainly the non ionic links like peptide group and breaks the hydrogen bond. Urea and acetic treatments improved water vapor permeability considerably. The water vapour permeability of experimental crust and finished leathers are better when compared with conventionally processed leathers. Even though surface finish coatings affect the water permeability, the effect was found to be negligible. The porosity parameters described in Figure 1 indicate the leathers which have undergone integrated treatment with acetic acid and urea have better porosity compared to conventional leathers.

Table 1: Water vapor permeability and physical characteristics of crust leathers

\begin{tabular}{|c|c|c|c|c|c|c|c|}
\hline \multirow{2}{*}{$\begin{array}{l}\mathrm{S} \\
\text { No }\end{array}$} & \multirow{2}{*}{ Experiments } & \multicolumn{2}{|c|}{$\begin{array}{l}\text { Water vapor permeability } \\
\qquad\left(\mathrm{mg} / \mathrm{cm}^{2} / \mathrm{hr}\right)\end{array}$} & \multicolumn{2}{|c|}{ Tensile strength $\left(\mathrm{N} / \mathrm{mm}^{2}\right)$} & \multicolumn{2}{|c|}{ Elongation at break $(\mathrm{mm})$} \\
\hline & & Control & Experiment & Control & Experiment & Control & Experiment \\
\hline \multicolumn{8}{|c|}{ Enzymatic interventions } \\
\hline 1 & Unhairing & $9 \pm 0.5$ & $12 \pm 0.5$ & $21 \pm 0.5$ & $31 \pm 0.5$ & $76 \pm 0.5$ & $88 \pm 0.5$ \\
\hline 2 & Bating & $7 \pm 0.5$ & $10 \pm 0.5$ & $25 \pm 0.5$ & $32 \pm 0.5$ & $74 \pm 0.5$ & $87 \pm 0.5$ \\
\hline 3 & Degreasing & $9 \pm 0.5$ & $12 \pm 0.5$ & $21 \pm 0.5$ & $29 \pm 0.5$ & $78 \pm 0.5$ & $89 \pm 0.5$ \\
\hline \multicolumn{8}{|c|}{ Chemical methods } \\
\hline 4 & Acetic acid treatment & $8 \pm 0.5$ & $11 \pm 0.5$ & $24 \pm 0.5$ & $34 \pm 0.5$ & $76 \pm 0.5$ & $89 \pm 0.5$ \\
\hline 5 & Urea treatment & $10 \pm 0.5$ & $13 \pm 0.5$ & $24 \pm 0.5$ & $29 \pm 0.5$ & $77 \pm 0.5$ & $89 \pm 0.5$ \\
\hline \multicolumn{8}{|c|}{ Integrated experiments } \\
\hline 6 & $\begin{array}{c}\text { Integrated - Acetic acid } \\
\text { treatment }\end{array}$ & $11 \pm 0.5$ & $18 \pm 0.5$ & $23 \pm 0.5$ & $33 \pm 0.5$ & $75 \pm 0.5$ & $86 \pm 0.5$ \\
\hline 7 & $\begin{array}{l}\text { Integrated - Urea } \\
\text { treatment }\end{array}$ & $15 \pm 0.5$ & $20 \pm 0.5$ & $24 \pm 0.5$ & $35 \pm 0.5$ & $78 \pm 0.5$ & $89 \pm 0.5$ \\
\hline
\end{tabular}

Table 2: Water vapor permeability of finished leathers

\begin{tabular}{|c|c|c|c|}
\hline \multirow{2}{*}{ S. No } & \multirow{2}{*}{ Experiment } & \multicolumn{2}{|c|}{ Water vapor permeability $\left(\mathrm{mg} / \mathrm{cm}^{2} / \mathrm{hr}\right)$} \\
\hline & & Control & Experiment \\
\hline \multicolumn{4}{|c|}{ Enzymatic interventions } \\
\hline 1 & Unhairing & $7 \pm 0.5$ & $10 \pm 0.5$ \\
\hline 2 & Bating & $6 \pm 0.5$ & $9 \pm 0.5$ \\
\hline 3 & Degreasing & $7 \pm 0.5$ & $9 \pm 0.5$ \\
\hline \multicolumn{4}{|c|}{ Chemical methods } \\
\hline 4 & Acetic acid treatment & $7 \pm 0.5$ & $10 \pm 0.5$ \\
\hline 5 & Urea treatment & $7 \pm 0.5$ & $12 \pm 0.5$ \\
\hline \multicolumn{4}{|c|}{ Integrated experiments } \\
\hline 6 & Integrated - Acetic acid treatment & $8 \pm 0.5$ & $14 \pm 0.5$ \\
\hline 7 & Integrated - Urea treatment & $12 \pm 0.5$ & $15 \pm 0.5$ \\
\hline
\end{tabular}

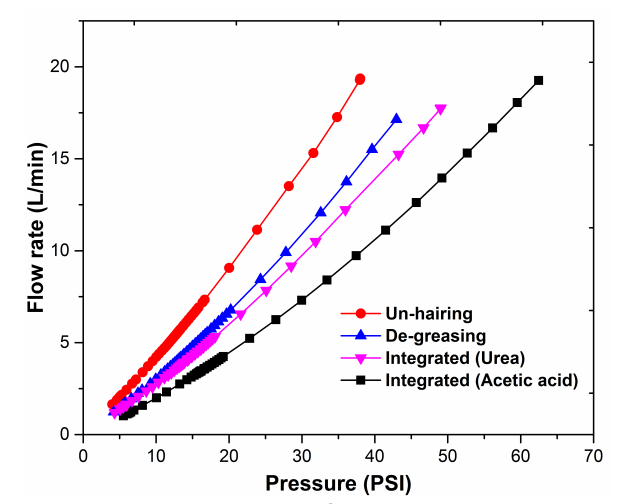

Figure 1. Porosity of experimental leathers 
The physical testing characteristics of the crust leathers indicate that strength properties such as tensile, tear, grain crack are comparable for experimental and conventional leathers (Table 3).

Table 3: Physical characteristics of experiments

\begin{tabular}{|c|c|c|c|c|c|c|c|}
\hline \multirow[t]{2}{*}{ S. No } & \multirow[t]{2}{*}{ Experiments } & \multicolumn{2}{|c|}{ Tear Strength $(\mathrm{N})$} & \multicolumn{2}{|c|}{ Load at grain crack $(\mathrm{N})$} & \multicolumn{2}{|c|}{$\begin{array}{l}\text { Distension at grain crack } \\
\qquad(\mathrm{mm})\end{array}$} \\
\hline & & Control & Experiment & Control & Experiment & Control & Experiment \\
\hline \multicolumn{8}{|c|}{ Enzymatic interventions } \\
\hline 1 & Unhairing & $41 \pm 2$ & $44 \pm 2$ & $205 \pm 6$ & $213 \pm 6$ & $8 \pm 0.5$ & $9 \pm 0.5$ \\
\hline 2 & Bating & $41 \pm 2$ & $44 \pm 2$ & $213 \pm 6$ & $220 \pm 6$ & $7 \pm 0.5$ & $8 \pm 0.5$ \\
\hline 3 & Degreasing & $42 \pm 2$ & $43 \pm 2$ & $208 \pm 6$ & $213 \pm 6$ & $7 \pm 0.5$ & $7 \pm 0.5$ \\
\hline \multicolumn{8}{|c|}{ Chemical methods } \\
\hline 4 & Acetic acid treatment & $41 \pm 2$ & $43 \pm 2$ & $205 \pm 6$ & $215 \pm 6$ & $7 \pm 0.5$ & $7 \pm 0.5$ \\
\hline 5 & Urea treatment & $41 \pm 2$ & $42 \pm 2$ & $203 \pm 6$ & $210 \pm 6$ & $7 \pm 0.5$ & $7 \pm 0.5$ \\
\hline \multicolumn{8}{|c|}{ Integrated experiments } \\
\hline 6 & $\begin{array}{c}\text { Integrated - Acetic acid } \\
\text { treatment }\end{array}$ & $41 \pm 2$ & $42 \pm 2$ & $205 \pm 6$ & $215 \pm 6$ & $7 \pm 0.5$ & $7 \pm 0.5$ \\
\hline 7 & $\begin{array}{l}\text { Integrated - Urea } \\
\text { treatment }\end{array}$ & $41 \pm 2$ & $43 \pm 2$ & $204 \pm 6$ & $213 \pm 6$ & $7 \pm 0.5$ & $7 \pm 0.5$ \\
\hline
\end{tabular}

From the Scanning Electron micrographs (Figures 3.1-3.14), it is clear that the experimental leather fibres were separated from one another, but in the case of control leather fiber aggregates could be noticed ( $2.1 \& 2.2$ ). In addition, SEM of the cross section of the enzymatic dehairing and bating processed experimental leather fibers showed a significant opening up of fiber bundles (Figures $3.2 \& 3.4$ ) and fine grain surface (Figures

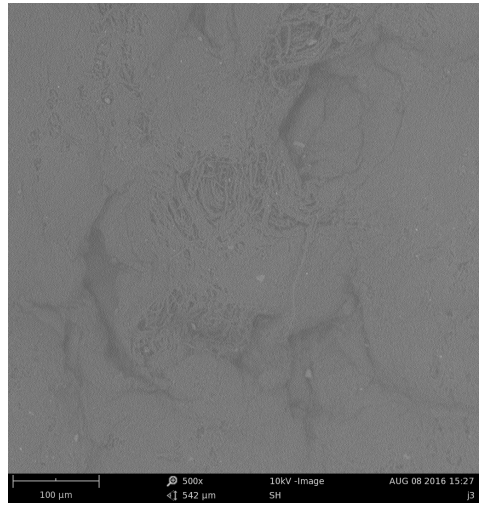

1. Grain surface - Control
3.1 \& 3.3). It was also observed that the SEM of the samples of acetic acid treatment and urea treatment has a smooth fiber, firmness grain and modified handle, which are good evidence of better water vapour permeability. The results indicate that experimental leathers have more and uniform fibre splitting as compared to that of conventional leathers.

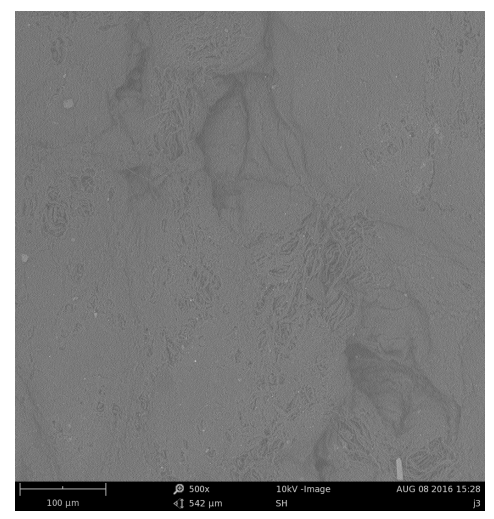

2. Cross section - Control

Figure 2. SEM of Control leathers 


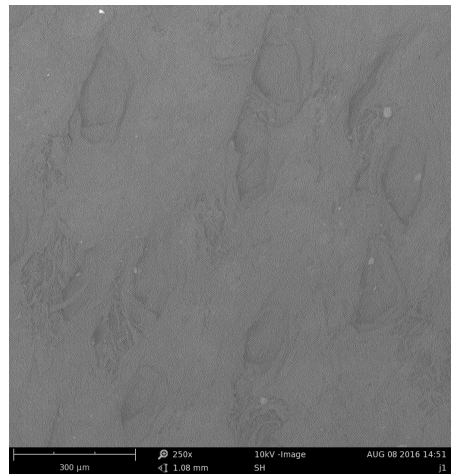

1. Grain surface - Unhairing Experiment

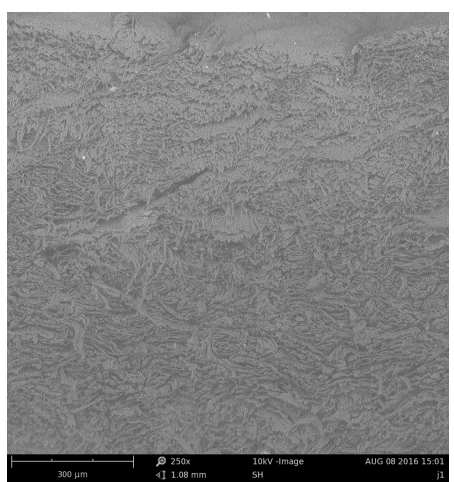

3. Grain surface - Bating Experiment

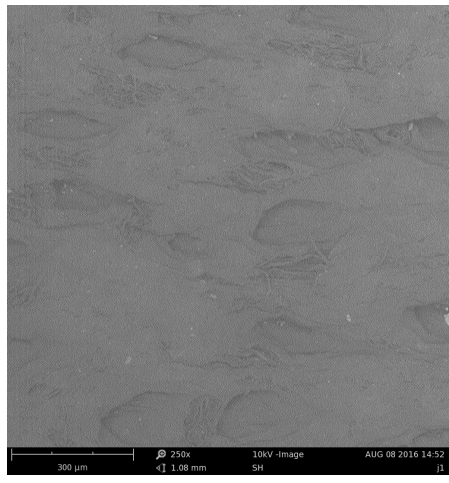

5. Grain surface - Degreasing Experiment

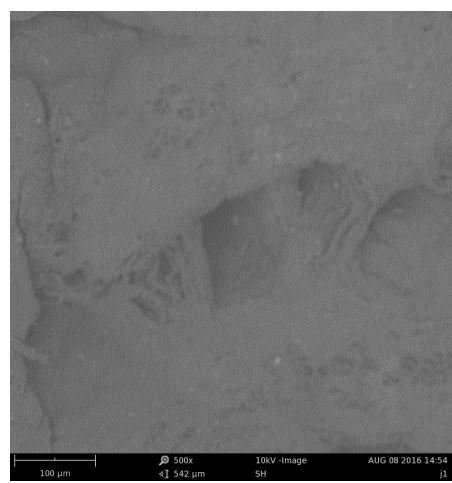

7. Grain surface - Acetic acid treatment Experiment

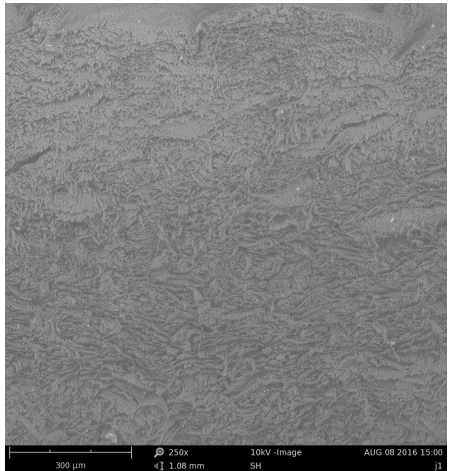

2. Cross section - Unhairing Experiment

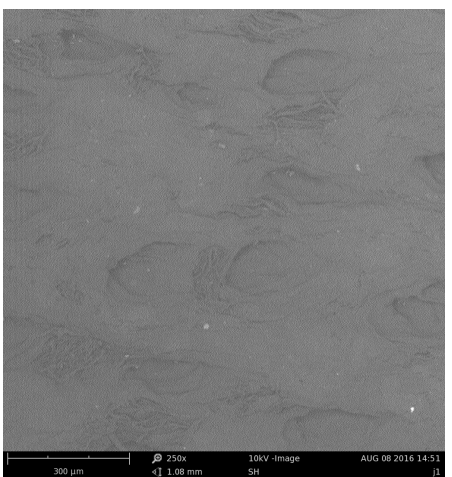

4. Cross section - Bating Experiment

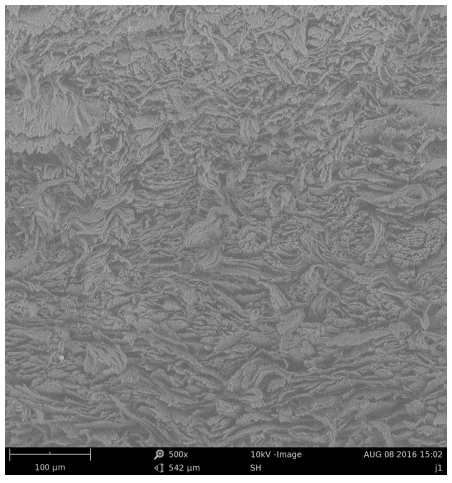

6. Cross section - Degreasing Experiment

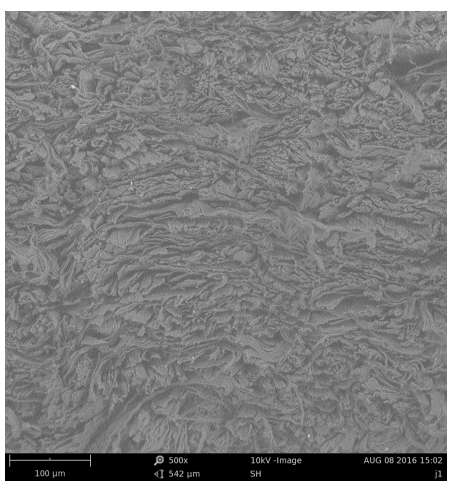

8. Cross section - Acetic acid treatment Experiment 


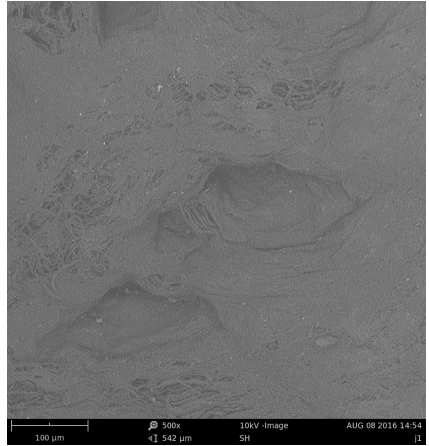

9. Grain surface - Urea Treatment

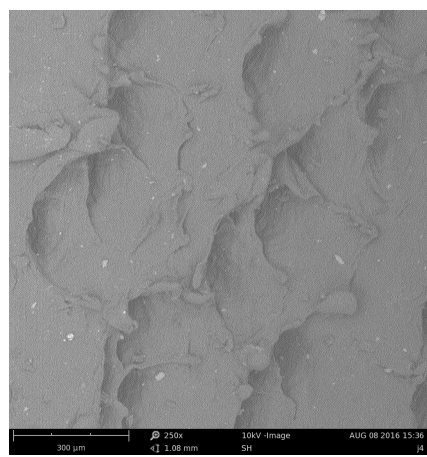

11. Grain surface - Integrated Acetic acid Treatment

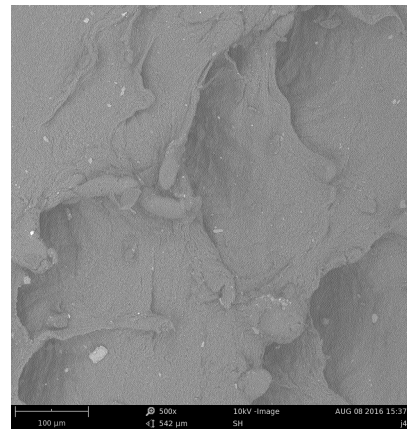

11. Grain surface - Integrated Urea Treatment

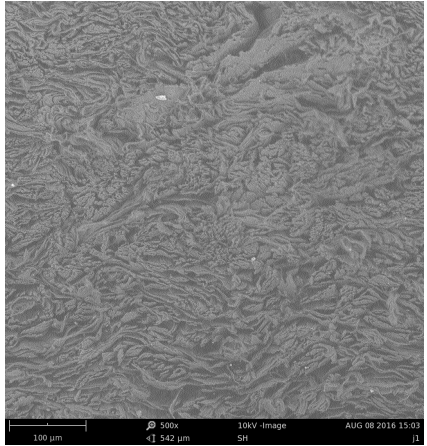

10. Cross section - Urea Treatment

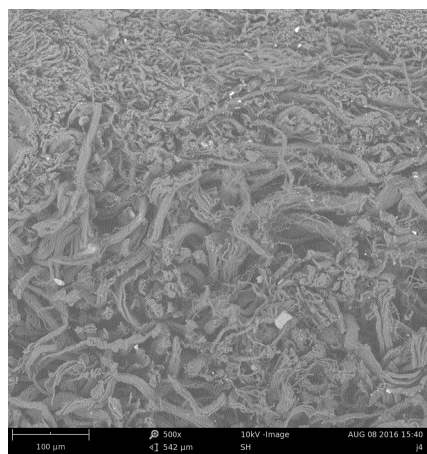

12. Cross section - Integrated Acetic acid Treatment

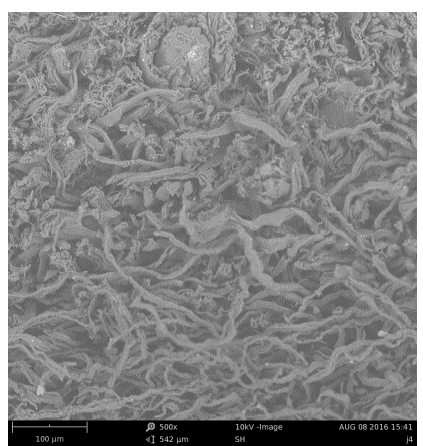

12. Cross section - Integrated Ureea Treatment

Figure 3. SEM of experimental leathers

\section{CONCLUSIONS}

The objective of improving water vapor permeability through enzymatic and chemical methods has been achieved without affecting other mechanical properties of leathers. When compared to acetic acid treatment, urea treatment has resulted in increased water vapor permeability. There was not much variation in strength properties between control and experiments with chemical and enzymatic treatments. Differences in water vapour permeability between crust and finished leathers were minimal. The approach provides an opportunity to improve the needed functional properties of leathers.

\section{REFERENCES}

1. Seligsberger, L., The Absorption of Water Vapor by Leather, J Am Leather Chem As, 1965, 60, 402-419. 
2. Mitton, R.G., The Diffusion of Water Vapor in Leather, J Soc Leath Tech Ch, 1955, 39, 385399.

3. Kanagy, J.R., Vickers, R.A., Factors Affecting the Water Vapor Permeability of Leather, $J$ Am Leather Chem As, 1950, 45, 211-241.

4. Landmann, A.W., Sofia, A., The Effect of Retannage and Nature of the Finish on Water Vapor Permeability and other Characteristics of the Finished Leather, J Soc Leath Tech Ch, 1970, 54, 3-26.

5. Seligsberger, L., Water Vapor Permeability of Leather and Leather like Sheet Materials: A New Approach, J Am Leather Chem As, 1975, 70, 3, 98-113.

6. Marshall, F.F., Williams, D., Permeability of Leather to Water Vapor, J Am Leather Chem As, 1946, 41, 6-19.

7. Taylor, M.M., Bailey, D.G., Feairheller, S.H., A Review of the Uses of Enzymes in the Tannery, J Am Leather Chem As, 1987, 82, 153-165.

8. Kanagy, J.R., Adsorption of Water Vapor by Untanned Hide and Various Leathers at $100^{\circ} \mathrm{F}$, J Am Leather Chem As, 1947, 42, 98-117.
9. Andrew, G.G., Gary, L.D., William, N.M., Chad, E.M., Unhairing with Proteolytic Enzymes Derived from Streptomyces griseus, J Am Leather Chem As, 2002, 97, 406-411.

10. Ludwig, S., Determination of the Surface Absorption of Water Vapor and Liquid Water by Leather and other Sheet Materials, J Am Leather Chem As, 1974, 69, 236-256.

11. Saryan, S.S., A Method of Determination of Water Vapor Absorption and Simultaneous Transmission through Shoe Upper Material, $J$ Am Leather Chem As, 1969, 64, 50-62.

12. Marcinkowska, E., Zuk, W., Water Vapor Permeability Measurement with the 'HY TESTER' Physical Simulator, I Am Leather Chem As, 2001, 96, 3, 94-102.

(C) 2017 by the author(s). Published by INCDTPICPI, Bucharest, RO. This is an open access article distributed under the terms and conditions of the Creative Commons Attribution license (http://creativecommons.org/licenses/by/4.0/). 


\title{
PRESSURE DISTRIBUTION PATTERNS AND SHAPES OF FOOT UNDER LONG-TERM LOADS
}

\author{
Yunpeng TANG \\ Guizhou University of Commerce, Guiyang 550014, China, tang762267@163.com
}

PRESSURE DISTRIBUTION PATTERNS AND SHAPES OF FOOT UNDER LONG-TERM LOADS

\begin{abstract}
In this paper, we use instruments to scan the feet of athletes with no foot disease or previous injury from Beijing Sport University and ordinary college students from Tsinghua University and obtain the foot shapes and the changes therein of the subjects. Then we design and extract indices like foot length and foot width, perform statistic analysis of the foot shapes of young athletes under different loads, and obtain a group of data regarding the foot shape features of young athletes under different loads. This group of data can provide experimental operation experience and data support for the establishment of national young athlete foot shape index database. By analyzing the differences between the foot shape indices of young athletes under different loads, we find that different loads have some impacts on the foot shape changes. There are great differences between the foot shape indices of young athletes and ordinary college students in China, and of the young athletes in China, foot shape indices like foot length and width are likely to vary greatly due to different loads.
\end{abstract}

KEY WORDS: young athletes, foot shapes, different loads, characteristic index

\section{TIPARELE DE DISTRIBUȚIE A PRESIUNII ȘI FORMA PICIORULUI SUB SARCINI PE TERMEN LUNG}

REZUMAT. În această lucrare s-a obținut forma piciorului și modificările acestuia prin scanarea picioarelor unor sportivi din cadrul Universității de Sport din Beijing care nu au avut boli sau răni anterioare la nivelul picioarelor, și ale unor studenți obișnuiți ai Universității Tsinghua. Apoi s-au proiectat și extras indici precum lungimea și lățimea piciorului, s-a efectuat analiza statistică a formelor picioarelor sportivilor tineri sub sarcini diferite și s-a obtinut un grup de date privind caracteristicile formei piciorului sportivilor tineri sub diferite sarcini. Acest grup de date poate constitui o bază pentru experimente și un suport pentru crearea unei baze naționale a indicilor privind forma piciorului sportivilor. Analizând diferențele dintre indicii de formă a piciorului sportivilor tineri sub sarcini diferite, constatăm că diferite sarcini au impact asupra modificării formei piciorului. Există mari diferențe între indicii de formă a piciorului la sportivii tineri și studenții obișnuiți din China, iar în cazul tinerilor sportivi din China, indicii de formă a piciorului, cum ar fi lungimea și lățimea piciorului, pot varia foarte mult datorită sarcinilor diferite.

CUVINTE CHEIE: sportivi tineri, forma piciorului, sarcini diferite, indice caracteristic

\section{LES MODÈLES DE DISTRIBUTION DE PRESSION ET LES FORMES DU PIED SOUS DES PRESSIONS À LONG TERME}

RÉSUMÉ. Dans cet article, on utilise des instruments pour scanner les pieds des athlètes sans maladie du pied ou des blessures antérieures de l'Université sportive de Pékin et des étudiants universitaires ordinaires de l'Université de Tsinghua et on obtient les formes des pieds et leurs changements. Ensuite, on conçoit et on extrait des indices comme la longueur du pied et la largeur du pied, on fait une analyse statistique des formes des pieds des jeunes athlètes sous différentes pressions et on obtient un groupe de données concernant les caractéristiques de la forme du pied des jeunes athlètes sous différentes pressions. Ce groupe de données peut servir comme une base à des expériences et un soutien pour créer une base de données nationale pour les indices des formes du pied d'athlètes. En analysant les différences entre les formes du pied des jeunes athlètes sous différentes pressions, on a constaté que les différentes pressions ont eu un impact sur le changement de forme du pied. Il existe de grandes différences entre les indices des formes du pied chez les jeunes athlètes et les étudiants ordinaires en Chine ; chez les jeunes athlètes chinois, les indices telles que la longueur et la largeur du pied peuvent varier considérablement en raison de différentes pressions.

MOTS CLÉS: jeunes athlètes, formes des pieds, différentes pressions, indice caractéristique

\section{INTRODUCTION}

Foot shape varies greatly under the influences of factors like race, region, inheritance and life style [1]. For an individual, in human body support, balance and motion, affected by various factors like body weight, standing posture, exercise task and habit, exercise method and intensity and shoes, foot shape would also change accordingly [2]. And foot shape in turn affects the human body support, balance and movements.
As part of the human parameters of the main nationality in a country, foot shape features and the change patterns thereof have attracted the attention of scholars. After years of hard work, the public welfare project "Chinese foot shape database" in China has obtained numerous raw data. These data were collected through the field sampling measurement of people living in seven regions, namely North China, Northwest China, Southwest China, South China, Mid-South China, Northeast China and East China, which are very essential to the research on the foot shapes and

\footnotetext{
* Correspondence to: Yunpeng TANG, Guizhou University of Commerce, Guiyang 550014, China, tang762267@163.com
} 
patterns of populations in different areas [3]. This test mainly measured and recorded the foot length, width and girth and locations and lengths of the first metatarsophalangeal joint and the fifth metatarsophalangeal joint where there are obvious bone marks. The data obtained have become the foundation for research in medical and shoemaking fields. With the international development of sports and the increasingly fierce sports competition in the world, how to design hi-tech sports equipment to improve athletic performance has become an important research subject in countries all over the world. The first contactless laser 3D foot scanner in China jointly developed by "Do-win Professional Sports Shoe R\&D Center", Tsinghua University and Beijing Sport University integrate foot scanning, shoe last design and manufacturing and can customize shoes for high performance athletes [4]. A domestic research institute has studied the effects of gait on foot in a specific group of people under different loads and found that the greater the load is, the more likely the foot will get rubbed and the more serious the blisters will be on the foot. Further discussion can be carried out on this research result.

To sum up, how to study the patterns of foot shapes of athletes doing different sports by using the foot scanning technology and design personalized sports shoes according to their foot shape features will become important research contents and can be extended to new applications and research in clinical biomechanics [5], human ergonomics and sports biomechanics.

In this paper, we mainly study the foot shapes of young athletes from colleges in China and obtain a group of foot shape indices of young athletes to provide data support for the establishment of the athlete foot shape database [6], discuss the change patterns of foot shapes of young athletes in China under different static loads to provide theoretical basis for the research and development of athletic shoes and build an index system reflecting the foot shape features of athletes to explore how to set athletic shoe standards.

\section{Foot shape index experiment}

In this experiment, 31 female and 66 male athletes with no previous foot injuries from Beijing Sport University and 20 female and 40 male ordinary college students from Tsinghua University are selected. Athletes to be tested have an average age of 19.8 and have been trained for 4.2 years on average. Their training results have all reached national Level 2 . These athletes include 62 runners, 17 jumpers and 18 throwers. The ordinary college students have an average age of 20.7, and none of them has had any athletic training or foot injury before. Basic information on the experiment is listed in Tables 1 and 2.

The first contactless laser 3D foot scanner in China developed by Tsinghua University can perform no-dead-zone measurement of foot shapes [7]. The motion platform drives the laser under the drive of the servo motor [8], fast scans the foot and obtains the two-dimensional image of each foot section, and in this way obtains the three-dimensional point cloud data of the foot [9]. The equipment is shown in Figure 1. Through the processing and reconstruction of the scanning data, we extract the three-dimensional feature size of the foot and establish a 3D model for the foot. The scanning point cloud diagram is shown in Figure 2. The foot load measuring unit, which consists of multiple pressure sensors in the system, can measure and display the load size of the measured foot in real time [10].

Table 1: Information about the test

\begin{tabular}{ccc}
\hline & Young athletes & Ordinary college students \\
\hline Number of people & 97 & 60 \\
Age & $19.8 \pm 1.6$ & $20.7 \pm 1.6$ \\
Height $(\mathrm{cm})$ & $178.3 \pm 7.8$ & $170.0 \pm 7.3$ \\
Weight $(\mathrm{kg})$ & $71.0 \pm 7.9$ & $61.4 \pm 10.1$ \\
Shoe size(code) & $41 \pm 3$ & $40 \pm 2$ \\
\hline
\end{tabular}


Table 2: Basic information on the athletes

\begin{tabular}{ccccccccc}
\hline & $\begin{array}{c}\text { National Elite } \\
\text { Athletes }\end{array}$ & $\begin{array}{c}\text { National Level 1 } \\
\text { athletes }\end{array}$ & $\begin{array}{c}\text { National Level 2 } \\
\text { athletes }\end{array}$ & $\begin{array}{c}\text { 15 20 years } \\
\text { old }\end{array}$ & $\begin{array}{c}20 \sim 25 \\
\text { years old }\end{array}$ & Male & Female \\
\hline Runners & 4 & 19 & 39 & 18 & 44 & 42 & 20 \\
Jumpers & 0 & 10 & 7 & 7 & 10 & 13 & 4 \\
Throwers & 0 & 7 & 11 & 8 & 10 & 11 & 7 \\
Total & 4 & 36 & 57 & 33 & 64 & 66 & 31 \\
\hline
\end{tabular}

\section{ANALYSIS ON THE FOOT SHAPES OF ATHLETES UNDER DIFFERENT LOADS}

\section{Analysis on the Length Indices}

As shown in Table 3, the average foot length of athletes under different loads is $254.80 \pm 14.11 \mathrm{~mm}$, the average instep length is $149.62 \pm 15.44 \mathrm{~mm}$, the medial longitudinal arch length is $194.68 \pm 17.83 \mathrm{~mm}$, and the lateral

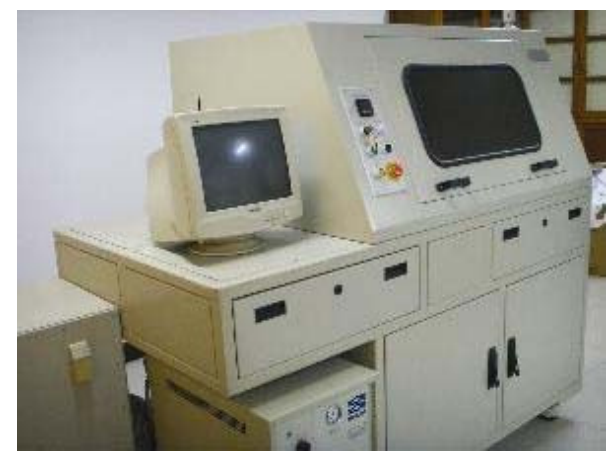

Figure 1. Contactless laser three-dimensional foot scanner

measured under $1 \mathrm{BW}+20 \mathrm{~kg}$;

- RW1 denotes: right foot measured under OBW; RW2 denotes: right foot measured under 1/2BW; RW3 denotes: right foot measured under 1BW; RW4 denotes: right foot measured under $1 \mathrm{BW}+20 \mathrm{~kg}$.

Eight groups of data including the foot length, instep length, medial longitudinal arch length and lateral longitudinal arch length of longitudinal arch length is $190.87 \pm 19.15 \mathrm{~mm}$.

Each subject is measured in four scenarios where the load is OBW, 1/2BW, 1BW and $1 \mathrm{BW} \pm 20 \mathrm{~kg}$ respectively, among them:

- LW1 denotes: left foot measured under OBW; LW2 denotes: left foot measured under $1 / 2 \mathrm{BW}$;

- LW3 denotes: left foot measured under 1BW; LW4 denotes: left foot

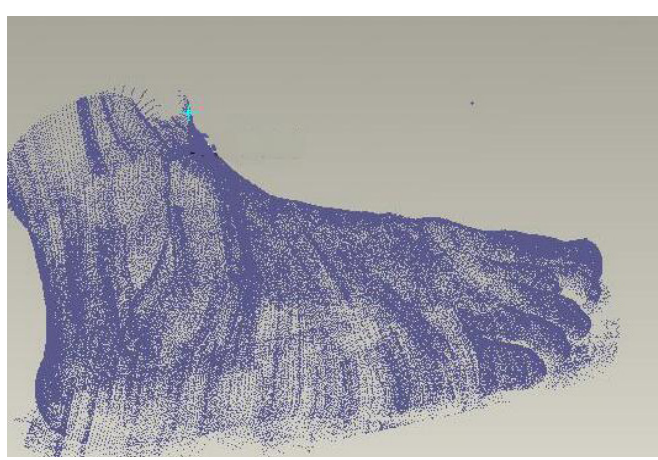

Figure 2. Scanned foot point cloud

the right and left feet are obtained. We perform analysis on the measured length indices and study the effects of different loads on the length indices [11].

As shown in Table 4 below, under different loads, the foot length indices of athletes all experience some changes. Under the same load, the data within one group have a greater degree of dispersion. The average values of the foot length indices of athletes all experience regular changes with the increasing load

Table 3: Basic information on length indices

\begin{tabular}{cccccc}
\hline & Data item & Average value & Standard deviation & Minimum value & $\begin{array}{c}\text { Maximum } \\
\text { value }\end{array}$ \\
\hline Foot length & 776 & 254.8 & 14.11 & 220 & 297 \\
Instep length & 776 & 149.62 & 15.44 & 101 & 198 \\
Medial longitudinal length & 776 & 194.68 & 17.83 & 144 & 244 \\
Lateral longitudinal length & 776 & 190.87 & 19.15 & 146 & 259 \\
\hline
\end{tabular}


and are all on the upward trend.

As shown in Table 5 below, under different loads, the foot length indices of athletes all experience some changes. Under the same load, the data within one group also have a greater degree of dispersion.

As shown in Table 6 above, under different loads, the medial longitudinal arch length of athletes changes. Under the same load, the data within one group have a greater degree of dispersion which have the same situation with Tables 4 and 5.
As shown in Figure 3, the average medial longitudinal arch lengths of athletes' right and left feet both experience regular changes with the increasing load and are all on the upward trend [12].

As shown in Figure 4, the average lateral longitudinal arch length of athletes' left feet reaches the maximum at a load of $\mathrm{OBW}$ and the minimum at a load of $1 / 2 \mathrm{BW}$, while for the right foot [13], the average lateral longitudinal arch length is the minimum at a load of OBW and the maximum at a load of $1 \mathrm{BW} \pm 20 \mathrm{~kg}$.

Table 4: Foot length indices under different loads

\begin{tabular}{lccccc}
\hline & Data item & Average value & Standard deviation & Minimum value & $\begin{array}{c}\text { Maximum } \\
\text { value }\end{array}$ \\
\hline LW1 & 96 & 253.42 & 13.777 & 220 & 290 \\
LW2 & 97 & 254.74 & 13.999 & 225 & 293 \\
LW3 & 97 & 255.6 & 14.441 & 227 & 297 \\
LW4 & 97 & 256.12 & 14.41 & 224 & 296 \\
RW1 & 96 & 253.5 & 14.016 & 226 & 289 \\
RW2 & 96 & 253.94 & 13.841 & 223 & 288 \\
RW3 & 96 & 255.27 & 14.319 & 227 & 294 \\
RW4 & 96 & 255.75 & 14.349 & 295 \\
\hline
\end{tabular}

Table 5: Instep length indices under different loads

\begin{tabular}{lccccc}
\hline & Data item & Average value & Standard deviation & Minimum value & $\begin{array}{c}\text { Maximum } \\
\text { value }\end{array}$ \\
\hline LW1 & 94 & 149.15 & 14.302 & 105 & 179 \\
LW2 & 95 & 150.05 & 15.94 & 114 & 182 \\
LW3 & 96 & 148.94 & 14.403 & 117 & 190 \\
LW4 & 96 & 148.39 & 15.433 & 114 & 186 \\
RW1 & 93 & 148.53 & 14.101 & 103 & 184 \\
RW2 & 94 & 149.21 & 16.864 & 111 & 193 \\
RW3 & 94 & 150.21 & 15.973 & 105 & 191 \\
RW4 & 94 & 149.31 & 16.713 & & 198 \\
\hline
\end{tabular}

Table 6: Medial Longitudinal arch length indices under different loads

\begin{tabular}{lccccc}
\hline & Data item & Average value & Standard deviation & Minimum value & $\begin{array}{c}\text { Maximum } \\
\text { value }\end{array}$ \\
\hline LW1 & 95 & 191.73 & 17.378 & 144 & 240 \\
LW2 & 96 & 193.97 & 16.375 & 144 & 239 \\
LW3 & 96 & 195.79 & 16.467 & 163 & 242 \\
LW4 & 96 & 196.07 & 17.585 & 164 & 243 \\
RW1 & 95 & 191.74 & 17.321 & 160 & 243 \\
RW2 & 94 & 193.85 & 19.156 & 151 & 243 \\
RW3 & 94 & 195.97 & 19.545 & 158 & 244 \\
RW4 & 95 & 198.33 & 18.245 & & 243 \\
\hline
\end{tabular}


In conclusion, a certain amount of load can cause significant changes in the medial longitudinal arch length and lateral longitudinal

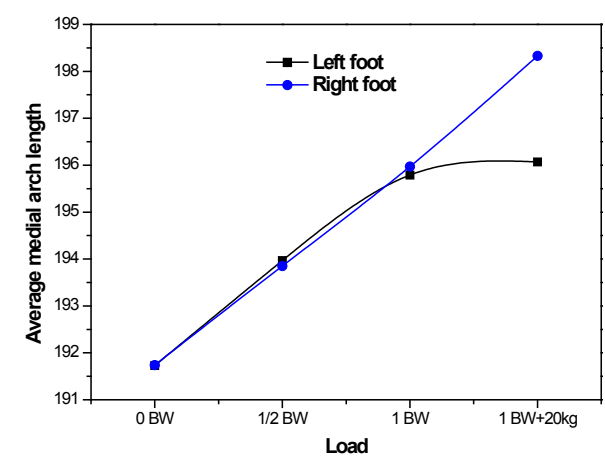

Figure 3. Average medial arch length under different loads

longitudinal arch length reflect the changes in the lateral longitudinal arch. The medial longitudinal arch length and lateral longitudinal arch length under a certain amount of load are significantly greater than those under no load, but when the load reaches a certain value, with the load increasing, the medial longitudinal arch length and lateral longitudinal arch length do not vary greatly [14].

\section{Distribution of Length Indices under Different Loads}

By major, the athletes are classified into three groups - runners, jumpers and throwers. By studying the indices of athletes of different majors under different loads, we analyze the effects of different majors on foot length indices, as shown in Table 7. We check and compare the foot length indices of the athletes of three majors under different loads, and find that for runners, the average foot length, medial longitudinal arch length and lateral longitudinal arch length are the smallest, and their average instep length is the largest; for jumpers, the average medial longitudinal arch length and lateral longitudinal arch length are the largest and the average foot length and instep length are medium; and for throwers, the average foot length is the largest, the average instep length is the smallest and the average medial longitudinal arch length and lateral longitudinal arch length are medium. arch length. Changes in the medial longitudinal arch length reflect the changes in the medial longitudinal arch while those in the lateral

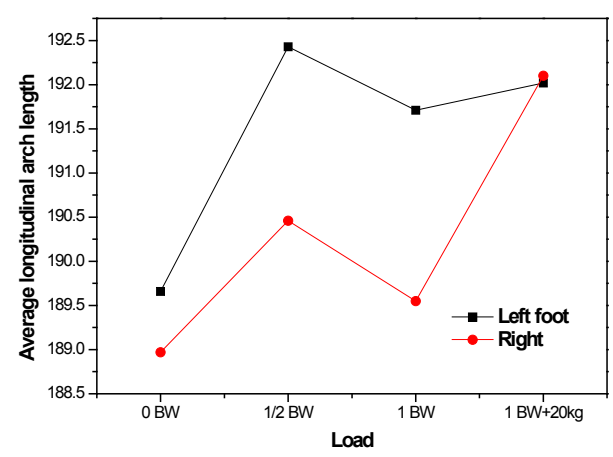

Figure 4. Average longitudinal arch length under different loads

We perform independent sample test on the length indices of runners, jumpers and throwers. According to the results, runners and jumpers have significant differences in the foot length, medial longitudinal arch length and lateral longitudinal arch length; runners and throwers vary greatly in foot length, instep length, medial longitudinal arch length and lateral longitudinal arch length; and jumpers and throwers vary greatly in foot length and medial longitudinal arch length. However, there is not much difference in the instep length and lateral longitudinal arch length.

\section{Distribution of Width Indices under Different Loads}

As shown in Table 8, the average foot width of athletes is $95.89 \pm 7.15 \mathrm{~mm}$, the minimum value is $75 \mathrm{~mm}$ and the maximum value is $124 \mathrm{~mm}$; the average heel width is $71.28 \pm 9.69 \mathrm{~mm}$, the minimum value is $58 \mathrm{~mm}$ and the maximum value is $114 \mathrm{~mm}$.

By measuring each subject in four scenarios where the load is $0 \mathrm{BW}, 1 / 2 \mathrm{BW}, 1 \mathrm{BW}$ and $1 \mathrm{BW} \pm 20 \mathrm{~kg}$ respectively, we obtain the data regarding the foot width and heel width and study the effects of different loads on the width indices.

As shown in Table 9, under different loads, the foot heel width indices of athletes all experience some changes. Under the same load, the data within one group have a smaller degree of dispersion. The average values of the 
foot width indices of athletes all experience regular changes with the increasing load and are all on the upward trend as can be seen in Figure 5. Under different loads, the heel widths of athletes all experience some changes. As shown in Figure 6, with the increasing load, the change patterns of heel widths of athletes are irregular. In the OBW case, the average heel width is the smallest; in the 1/2BW case, the average value is the largest; in the 1BW case, it is between the average values in the $1 / 2 \mathrm{BW}$ and $1 \mathrm{BW} \pm 20 \mathrm{~kg}$ cases.

Table 7: Basic information on the average values of length indices of different athletes

\begin{tabular}{|c|c|c|c|c|c|c|c|c|c|}
\hline \multicolumn{10}{|c|}{ 95\% mean difference confidence interval } \\
\hline & & $\begin{array}{l}\text { Sample } \\
\text { size }\end{array}$ & $\begin{array}{l}\text { Average } \\
\text { value }\end{array}$ & $\begin{array}{l}\text { Standard } \\
\text { deviation }\end{array}$ & $\begin{array}{l}\text { Standard } \\
\text { error }\end{array}$ & $\begin{array}{l}\text { Minimum } \\
\text { value }\end{array}$ & $\begin{array}{c}\text { Maximum } \\
\text { value }\end{array}$ & $\begin{array}{l}\text { Minimum } \\
\text { value }\end{array}$ & $\begin{array}{l}\text { Maximum } \\
\text { value }\end{array}$ \\
\hline \multirow{3}{*}{ Foot length } & Runners & 496 & 251.37 & 13.443 & 0.604 & 250.19 & 252.56 & 220 & 284 \\
\hline & Jumpers & 136 & 256.32 & 11.815 & 1.013 & 257.32 & 261.32 & 239 & 284 \\
\hline & Throwers & 139 & 262.58 & 14.278 & 1.211 & 260.19 & 264.98 & 228 & 297 \\
\hline \multirow{3}{*}{ Instep length } & Runners & 482 & 150.41 & 14.773 & 0.673 & 149.09 & 151.73 & 101 & 198 \\
\hline & Jumpers & 135 & 148.82 & 15.712 & 1.352 & 146.14 & 151.49 & 114 & 179 \\
\hline & Throwers & 139 & 145.49 & 16.870 & 1.431 & 142.66 & 148.32 & 103 & 190 \\
\hline \multirow{3}{*}{$\begin{array}{c}\text { Medial } \\
\text { longitudinal } \\
\text { arch length }\end{array}$} & Runners & 494 & 191.82 & 16.529 & 0.744 & 190.35 & 193.28 & 144 & 234 \\
\hline & Jumpers & 128 & 202.64 & 17.349 & 1.533 & 199.61 & 205.68 & 167 & 239 \\
\hline & Throwers & 139 & 197.54 & 20.038 & 1.700 & 194.18 & 200.90 & 159 & 244 \\
\hline \multirow{3}{*}{$\begin{array}{l}\text { Lateral } \\
\text { longitudinal } \\
\text { arch length }\end{array}$} & Runners & 493 & 188.31 & 18.930 & 0.853 & 186.63 & 189.98 & 146 & 249 \\
\hline & Jumpers & 136 & 196.35 & 17.134 & 1.469 & 193.45 & 199.26 & 169 & 259 \\
\hline & Throwers & 139 & 194.62 & 20.128 & 1.707 & 191.24 & 197.99 & 150 & 244 \\
\hline
\end{tabular}

Table 8: The basic unit of the width index of athletes Unit ( $\mathrm{mm}$ )

\begin{tabular}{cccccc}
\hline & Data item & Average & Standard deviation & Minimum value & Maximum \\
\hline Foot width & 771 & 95.89 & 7.15 & 75 & 124 \\
Heel Width & 770 & 71.28 & 9.69 & 58 & 114 \\
\hline
\end{tabular}

By major, the athletes are classified into three groups - runners, jumpers and throwers. By studying the indices of athletes of different majors under different loads, we analyze the effects of different majors on foot width indices, as shown in Figures 7 and 8.

Table 9: Length of the foot heel width under different loads

\begin{tabular}{|c|c|c|c|c|c|}
\hline & Data item & Average value & Standard deviation & Minimum value & Maximum \\
\hline LW1 & 96 & 70.60 & 8.951 & 48 & 110 \\
\hline LW2 & 97 & 73.2 & 9.630 & 56 & 110 \\
\hline LW3 & 97 & 71.88 & 9.766 & 53 & 110 \\
\hline LW4 & 97 & 72.08 & 10.377 & 48 & 110 \\
\hline RW1 & 96 & 69.50 & 9.074 & 53 & 96 \\
\hline RW2 & 96 & 71.63 & 8.763 & 58 & 95 \\
\hline RW3 & 96 & 70.53 & 9.769 & 53 & 96 \\
\hline RW4 & 95 & 70.78 & 10.932 & 48 & 114 \\
\hline
\end{tabular}


It can be seen that among the average foot width indices of athletes in three majors, the average foot width of runners is the smallest, followed by that of jumpers. The average foot width of throwers is the greatest, while the average heel width of jumpers is the smallest, that of the runners is medium and that of throwers is the largest. There are significant differences between runners and jumpers, runners and throwers and jumpers and throwers in terms of foot width and heel width.

Foot width is likely to change with different loads. Changes in this index mainly reflect the change pattern of the foot transverse arch under loads. Different loads have relatively small impact on the heel width. Changes in this index reflect the change pattern of the heel fat pad under loads. In the transition from OBW to

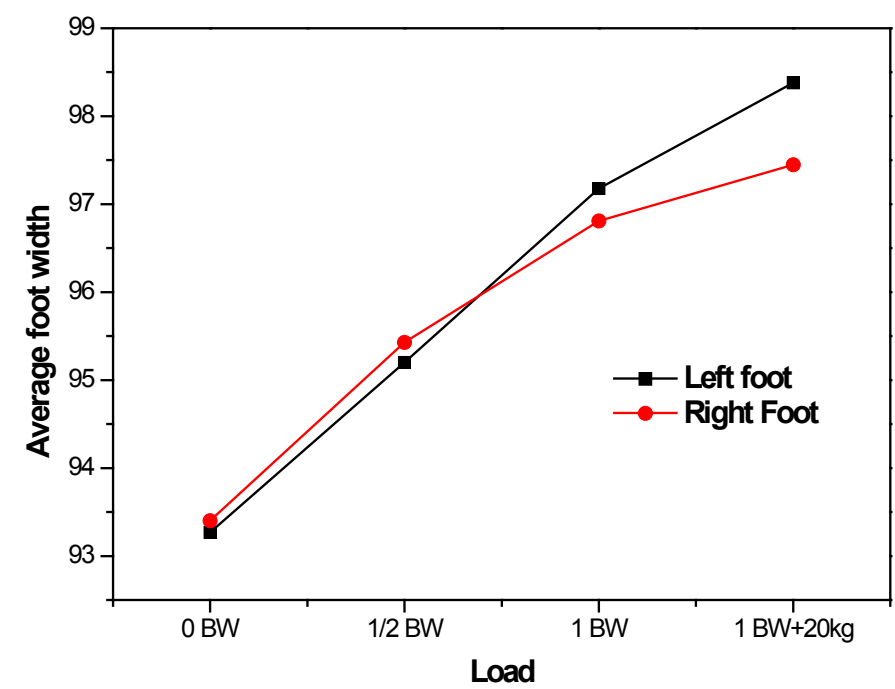

Figure 5. Average width of foot under different loads

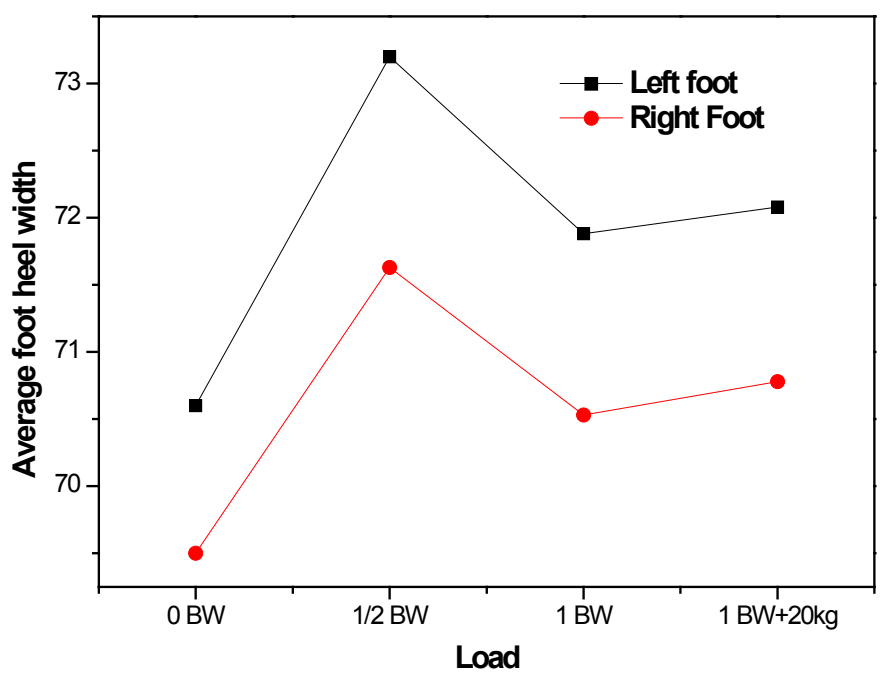

Figure 6. Average width of heel under different loads 
$1 / 2 \mathrm{BW}$, changes are obvious in the heel width, indicating that the heel fat pad changes greatly when it begins to bear load. Afterwards, with the load increasing, there is not much change in the heel width, indicating that additional load has no obvious impact on the heel width.

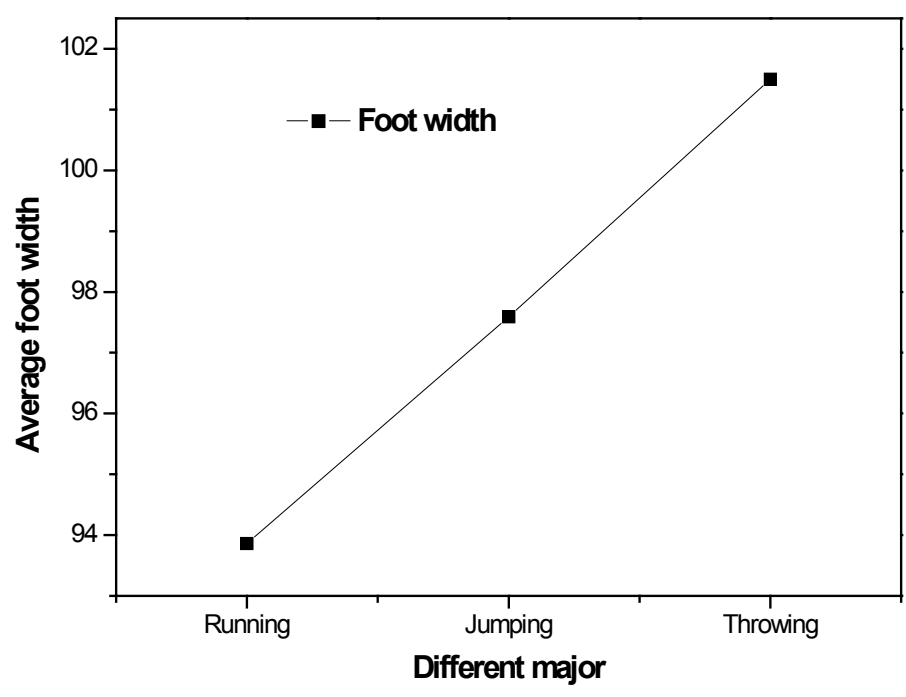

Figure 7. Average foot widths of athletes of different majors

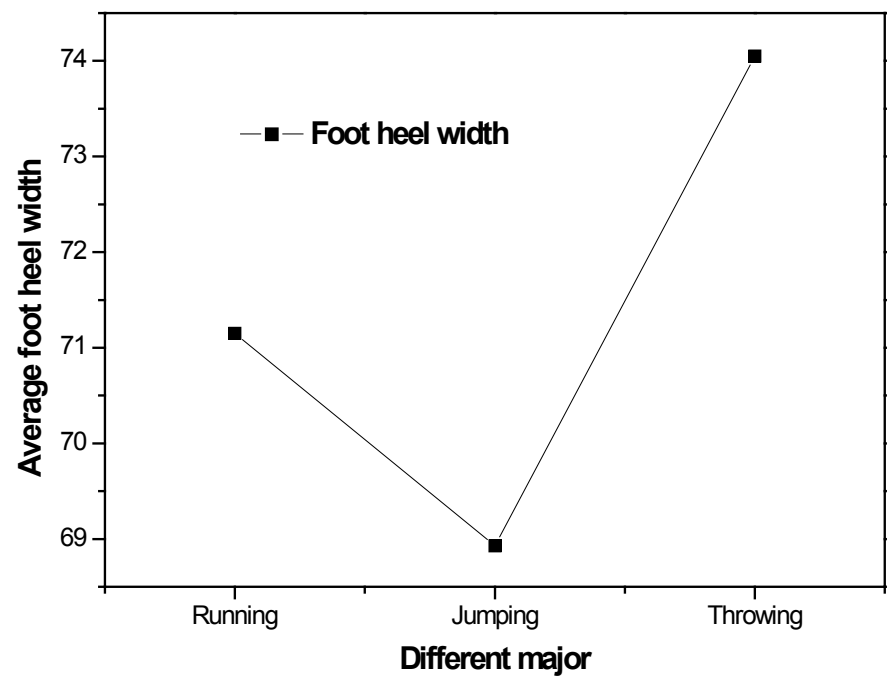

Figure 8. Average foot heel widths of athletes of different majors

Therefore, in shoemaking, the width of the metatarsophalangeal part should be more elastic than that of the heel to make the shoes more comfortable. In terms of foot width and heel width, there are significant differences between runners, jumpers and throwers. In future shoe last design, the great differences between the three types of athletes, especially in the foot width, which is an index reflecting the changes in the foot transverse arch, and the feature that throwers have the greatest foot width can all be taken into account. For example, the elastic range for the width of the metatarsophalangeal part can be increased as appropriate in the shoe last design for throwers in the future. 


\section{CONCLUSIONS}

In this paper, through the experimental design test, the young athlete's foot shape changes have been measured under different load parameters. The relevant data analysis shows that different loads have different impact on the foot shape changes. Besides, there are significant differences in the impact of different major sports on the foot shape indices. Specific conclusions are as follows:

(1) There are significant differences between runners, jumpers and throwers in terms of foot length and medial longitudinal arch length. In particular, the great differences between the three types of athletes in terms of the medial longitudinal arch length, which reflects the changes in the medial arch, can be taken into account in future shoe last design.

(2) Different loads have great impacts on the foot width. With the pressure increasing, the height of foot traverse arch is reduced, and the foot width gets larger, which further indicates that the foot traverse arch is quite sensitive to the load and can be easily increased with the increasing load. Therefore, in shoemaking, the width of the metatarsophalangeal part should be more elastic than that of the heel to make the shoes more comfortable.

The study of this paper has a positive effect on the biomechanics and clinical biomechanics of foot.

\section{REFERENCES}

1. Mihai, A., Dragomir, A., Driscu, M., Berijan, G., Comparative Study on the Assessment of Anthropometric Parameters Defining the 3D Shape of Diabetic and Arthritic Foot, Leather and Footwear Journal, 2009, 9, 1, 23-31.

2. Zhou, J., Zhang, W.W., Xu, B., Chen, W.Y, Effect of Arch Support on the Insole Pressure Distribution of Heel Heighted Shoes, Leather and Footwear Journal, 2012, 12, 4, 295-304.

3. Wang, J., Saito, H., Kimura, M., Mochimaru, M., Kanade, T., Human Foot Reconstruction from Multiple Camera Images with Foot Shape Database, IEICE Trans Inf Syst, 2008, E89-D, 5, 1732-1742, https://doi.org/10.1093/ietisy/ e89-d.5.1732.

4. Liu, G.Z., Wang, B.X., Shi, H., Luo, X.Z., Zhang, M.Z., Wang, R., Foot-Parameter-Extracting
Method Used in 3D Foot-Shape Measurement System, Chinese Journal of Biomedical Engineering, 2009.

5. Samson, W., Van, H.A., Sanchez, S., Chèze, L., Van, S.J.S., Feipel, V., Foot Roll-over Evaluation Based on 3D Dynamic Foot Scan, Gait Posture, 2014, 39, 1, 577, https://doi.org/10.1016/j. gaitpost.2013.09.014.

6. Ma, X., Luximon, A., 3D Foot Prediction Method for Low Cost Scanning, Int J Ind Ergon, 2014, 44, 6, 866-873, https://doi.org/10.1016/j. ergon.2014.08.006.

7. Kim, D.J., Bien, Z., Design of "Personalized" Classifier Using Soft Computing Techniques for "Personalized" Facial Expression Recognition, IEEE Trans Fuzzy Syst, 2008, 16, 4, 874-885, https://doi.org/10.1109/tfuzz.2008.924344.

8. Hodges, J.S., Peters, R.M., Non-Destructive Measurement of Foot/Notch on Etched Polysilicon Gates Using Spectroscopic Ellipsometry, IEEE International Symposium on Semiconductor Manufacturing, 2005, pp.406-409, IEEE Xplore. https://doi. org/10.1109/issm.2005.1513390.

9. Nurunnabi, A., West, G., Belton, D., Outlier Detection and Robust Normal-Curvature Estimation in Mobile Laser Scanning 3D Point Cloud Data, Pattern Recognit, 2015, 48, 4, 1404-1419, https://doi.org/10.1016/j. patcog.2014.10.014.

10. Harzhauser, M., Djuricic, A., Mandic, O., Zuschin, M., Dorninger, P., Nothegger, C. et al., Disentangling the History of Complex MultiPhased Shell Beds Based on the Analysis of 3D Point Cloud Data, Palaeogeogr Palaeoclimatol Palaeoecol, 2015, 437, 165-180, https://doi. org/10.1016/j.palaeo.2015.07.038.

11. Liu, G., Wang, B., Shi, H., Luo, X., Measurement System for 3-D Foot Shapes under Different Loads, International Technology and Innovation Conference 2006 (ITIC 2006), 246250, https://doi.org/10.1049/cp:20060763.

12. Kouchi, M., Analysis of Foot Shape Variation Based on the Medial Axis of Foot Outline, Ergonomics, 1995, 38, 9, 1911, https://doi. org/10.1080/00140139508925239.

13. Kouchi, M., Tsutsumi, E., Relation between the Medial Axis of the Foot Outline and 3-D Foot Shape, Ergonomics, 
1996, 39, 6, 853-861, https://doi. org/10.1080/00140139608964506.

14. Wunderlich, R.E., Griffin, N.L., Wickham, A.B., Gender Differences in Foot Function during Walking, Running and Turning: Implications for Overuse Injuries in Female Athletes, Clin Biomech, 2008, 23, 5, 705-706, https://doi. org/10.1016/j.clinbiomech.2008.03.050.
(C) 2017 by the author(s). Published by INCDTPICPI, Bucharest, RO. This is an open access article distributed under the terms and conditions of the Creative Commons Attribution license (http://creativecommons.org/licenses/by/4.0/). 


\title{
FOOTWEAR PROTECTION AGAINST FUNGI USING THYME ESSENTIAL OIL
}

\author{
Corina CHIRILĂ, Viorica DESELNICU, Mariana Daniela BERECHET
}

INCDTP - Division Leather and Footwear Research Institute, 93 lon Minulescu st., sector 3, 031215 Bucharest

ABSTRACT. Many natural antimicrobial agents have been identified over the last decades, such as essential oils, which have a proven effect against bacteria and fungi found on feet. This paper investigates antifungal activity of thyme essential oil against Trichophyton interdigitale on sheepskins for footwear lining. Thyme essential oil showed the best antifungal activity on sheepskins for footwear lining. Thyme oil offers a much safer alternative to toxic biocides. The results of this study may have potential for use in the development of applications in the sanitation of footwear components.

KEY WORDS: sheep skins lining leather, thyme essential oil, antifungal activity, Trichophyton interdigitale

\section{PROTEJAREA ÎNCĂLTĂMINTEI ÎMPOTRIVA FUNGILOR UTILIZÂND ULEIUL ESENTIAL DE CIMBRU}

REZUMAT. Numeroşi agenţi antimicrobieni naturali au fost identificaţi în ultimele decenii, printre aceștia numărându-se uleiurile esenţiale, care au un efect dovedit împotriva bacteriilor şi ciupercilor întâlnite la nivelul picioarelor. Această lucrare investighează activitatea antifungică a uleiului esenţial de cimbru împotriva ciupercii Trichophyton interdigitale asupra pieilor de oaie pentru căptuşirea încălţămintei. Uleiul esenţial de cimbru a prezentat cea mai bună activitate antifungică asupra pielii de oaie pentru căptuşirea încălţămintei. Uleiul de cimbru oferă o alternativă mult mai sigură la biocidele toxice. Rezultatele acestui studiu pot fi utilizate în dezvoltarea aplicaţiilor în igiena componentelor încălţămintei.

CUVINTE CHEIE: piei de oaie pentru căptușeală, ulei esenţial de cimbru, activitate antifungică, Trichophyton interdigitale

\section{LA PROTECTION DES CHAUSSURES CONTRE LES CHAMPIGNONS EN UTILISANT L'HUILE ESSENTIELLE DE THYM}

RÉSUMÉ. De nombreux agents antimicrobiens naturels ont été identifiés au cours des dernières décennies, telles que les huiles essentielles, qui ont un effet éprouvé contre les bactéries et les champignons trouvés sur les pieds. Cet article étudie l'activité antifongique de l'huile essentielle de thym contre Trichophyton interdigitale sur les peaux de mouton pour la doublure de la chaussure. l'huile essentielle de thym a présenté la meilleure activité antifongique sur les peaux de mouton pour la doublure de la chaussure. L'huile de thym offre une alternative beaucoup plus sûre aux biocides toxiques. Les résultats de cette étude peuvent être utilisés dans le développement d'applications pour l'assainissement des composants de la chaussure.

MOTS CLÉS: peaux de moutons pour la doublure, huile essentielle de thym, activité antifongique, Trichophyton interdigitale

\section{INTRODUCTION}

Odour is a key factor in limiting footwear lifetime as the causative compounds do not disappear immediately. It arises when sweat from feet is trapped inside the footwear materials and their components are degraded by feet microbiota [1]. A way to avoid or reduce bad shoe odours apart from foot care and hygiene measures is through the use of antimicrobial and/or deodorising agents. A wide range of antimicrobial compounds are commercially available. In the footwear industry, suitable antimicrobial technologies are mainly focused on metals and metal compounds (e.g. silver, copper, zinc, metal oxides, etc.). A few other compounds such as quaternary ammonium salts, borates, 2,4,4-trichloro-2-hydroxydiphenil ether (Triclosan) or 3-iodo-2-propynyl-butylcarbamate (IPBC), etc., are also used. However some of them may in some degree be extremely irritant, harmful and toxic for the environment and human health [2].

Many natural antimicrobial agents have been identified over the last decades, such as essential oils, which have a proven effect against bacteria and fungi found on feet.

The antifungal properties of essential oils have been thoroughly researched. Studies prove conclusively that certain essential oils work as powerful antifungals [3-5]. Some essential oils have the ability to kill parasites and fungal infections, which is why they are so popular for use in fighting toenail fungus, ringworm and athlete's * Correspondence to: Corina CHIRILĂ, INCDTP - Division Leather and Footwear Research Institute, 93 Ion Minulescu st., sector 3, 031215
Bucharest, e-mail: corina.chirila@icpi.ro 
foot [6-10]. Athlete's foot, also known as tinea pedis, is a fungal infection that affects the foot. It causes redness, peeling of skin, burning, itching and sometimes blisters and sores. Athlete's foot is a very common fungal infection. The fungus thrives best in a moist, warm environment such as wet socks, shoes, swimming pools, locker rooms, and wet floors of showers. Its occurrence is most common in summer and in warm, humid climates. It is frequently reported in people who wear tight shoes such as sneakers [11].

Keeping in mind the adverse reactions of antifungal medicines, natural remedies are a safe choice to treat fungal infections. They have no undesirable side effects or nasty drug interactions. Essential oils are a natural remedy for getting rid of fungal infections. Many essential oils have the capability to combat fungal infection. These oils are made up of complex chemical constituents, and researchers have found that many essential oils have antifungal properties. If used properly, essential oils with antifungal traits are a natural way to cure fungal diseases such as athlete's foot [11].

Kalemba and Kunicka [12] reported that essential oils derived from spices and herbs have some of the strongest antifungal properties. These essential oils include cinnamon, mint, thyme, sage, clove and origanum. Furthermore, Price and Price [13] list pine, tea tree, peppermint, basil and rosemary essential oils as having antifungal properties. Tea tree oil, especially, is proven to be effective against candida. This fact has been established in several studies, such as that of Shemesh and Mayo [14].

Thyme (Thymus vulgaris) is an herbal plant commonly used as a condiment or spice. Thyme oil and extracts are often used as an essential ingredient in many of the domestic herbal remedies. This essential oil contains thymol (natural monoterpene phenol derivative of cymene) that is beneficial for controlling infection caused by fungal and bacterial influence. It works exceedingly well for getting rid of toenail fungus [15].

According to one of the studies which examined the antifungal effects of a generic test rub, it is found that using thymol effectively suppressed the fungus that is responsible for toenail infection. Another study reported the effectiveness of thymol in eliminating candida fungus [16].

Extended studies were already reported for using essential oils as biocides in leather manufacture [17-21] and in footwear protection against microorganism growth which are mainly responsible for shoe bad odor [22-25].

The aim of this work is to test antifungal activity of essential oil extracted from thyme (Thymus vulgaris) against Trichophyton interdigitale on sheepskin leather used as lining in footwear production, in order to avoid or reduce bad shoe odour through the use of antimicrobial and/or deodorising agents.

\section{MATERIALS AND METHODS}

\section{Materials}

Essential oil isolated from thyme (Thymus vulgaris) was obtained by hydro distillation in a continuous Clevenger extractor [26];

Sheep skins for footwear linings unfinished and finished with synthetic film;

Biologic material: Trichophyton interdigitale.

\section{Methods}

Chemical composition of essential oils was determined by Gas chromatography-Mass Spectrometry (GC-MS) with Agilent 6890 N [26].

Antifungal activity against Trichophyton interdigitale: The tests were performed in accordance with ASTM D4576-86:2013 - Standard Test Method for Mold Growth Resistance of Wet Blue.

In each Petri dish Dextrose Agar Sabouraud culture medium was poured. Both samples treated with thyme essential oil and control samples were placed in each Petri dish in the center of the surface of the culture medium, and then the culture medium was seeded in 3 points around the sample, as an equilateral triangle. There have been two parallel samples. Petri dishes were placed in thermo-hygrostat at $30^{\circ} \mathrm{C}$ temperature and were analyzed after 3,7 , 14 and 21 days. 
Optical microscopy images were captured using a Leica stereomicroscope S8APO model with optic fiber cold light source, L2, with three levels of intensity, and magnification 40X.

\section{RESULTS AND DISCUSSION}

\section{Chemical Composition of Thyme Essential Oil}

Table 1 presents the main components of thyme essential oil determined by GC/GC-MS chromatography.

Table 1: Main chemical compounds identified in Thymus vulgaris essential oil

\begin{tabular}{|c|c|c|c|c|c|}
\hline No. & Retention time, $\min$ & Compound & Formula & $\%$ & $\begin{array}{c}\text { Kovats } \\
\text { Indices, } \mathrm{KI}\end{array}$ \\
\hline 1 & 23.060 & Carvacrol (Antioxine) & $\mathrm{C}_{10} \mathrm{H}_{14} \mathrm{O}$ & 57.355 & $2,291 \times 10^{3}$ \\
\hline 2 & 12.940 & Thymol & $\mathrm{C}_{10} \mathrm{H}_{16}$ & 32.430 & $1,095 \times 10^{3}$ \\
\hline 3 & 11.240 & o-Cymol & $\mathrm{C}_{10} \mathrm{H}_{14}$ & 3.993 & $1,057 \times 10^{3}$ \\
\hline
\end{tabular}

Analysis allowed the identification of 16 components of which, carvacrol $(57.355 \%)$ and thymol (32.430\%) and o-cymol (3.993\%) were detected as major constituents.

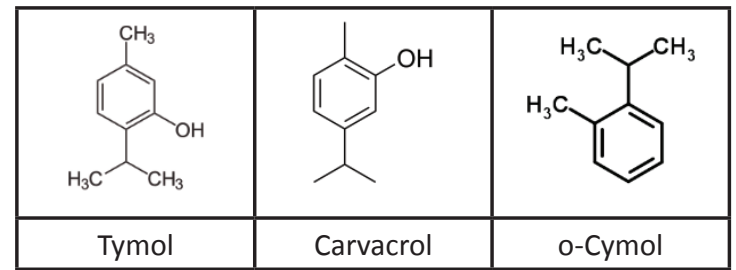

Thymol is a natural monoterpene phenol derivative of cymene, $\mathrm{C}_{10} \mathrm{H}_{14} \mathrm{O}$, isomeric with carvacrol; carvacrol, or cymophenol, $\mathrm{C}_{6} \mathrm{H}_{3} \mathrm{CH}_{3}(\mathrm{OH})$ $\left(\mathrm{C}_{3} \mathrm{H}_{7}\right)$, is a monoterpenoid phenol; o-cymol is o-isopropyltoluol.

\section{Antifungal Activity}

Table 2 presents antifungal activity against Trichophyton interdigitale after 3, 7, 14 and 21 days of incubation at $30^{\circ} \mathrm{C}$ of sheepskin leather treated with thyme essential oil.

Figure 1 . The main components of thyme essential oil

Table 2: Antifungal activity on sheepskin unfinished leather for lining treated with thyme essential oil against Trichophyton interdigitale

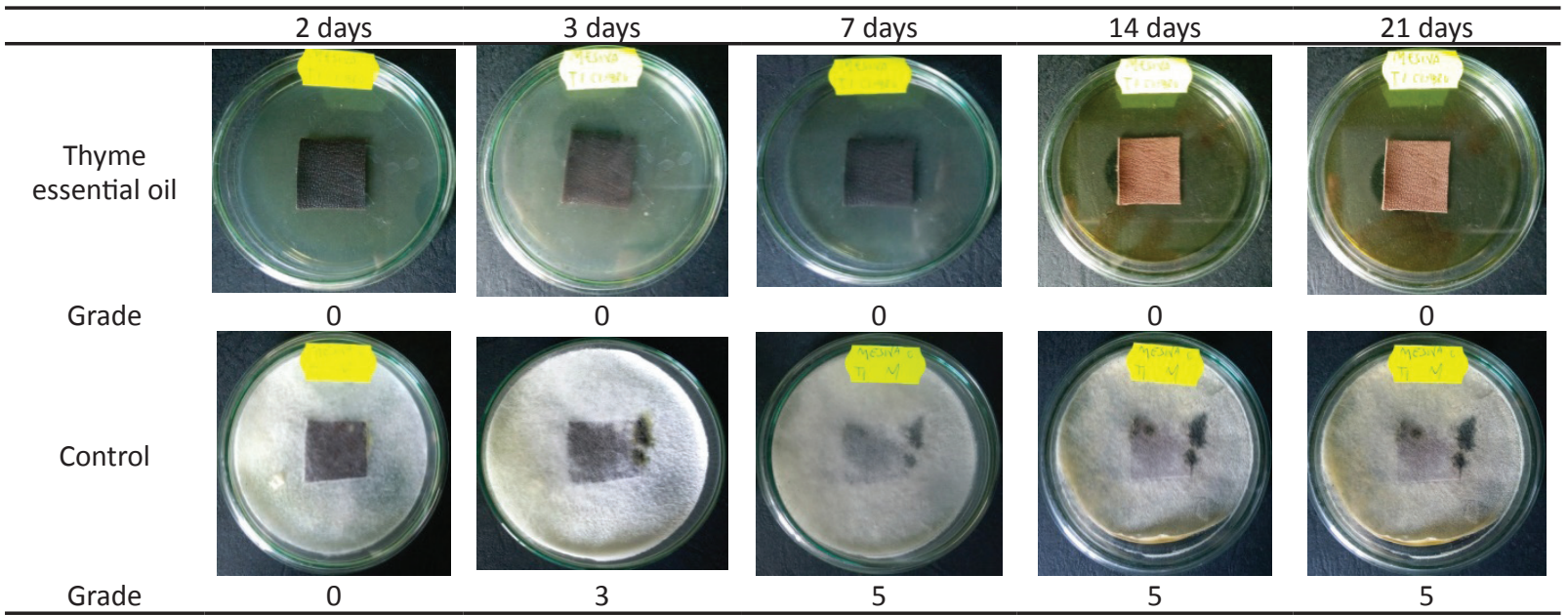


The thyme essential oil applied on lining leather completely inhibited the development of the Trichophyton interdigitale, with no increases until the end of the 21-day experiment. In the control samples, increases were observed after 2 days, and at the end of the experiment ( 21 days) the leather samples were completely covered by the pathogen.

Table 3 presents antifungal activity against Trichophyton interdigitale after 3, 7, 14 and 21 days of incubation at $30^{\circ} \mathrm{C}$ of sheepskin leather finished with synthetic film and treated with thyme essential oil.

Table 3: Antifungal activity on sheepskin leather for lining finished with synthetic film and treated with thyme essential oil against Trichophyton interdigitale

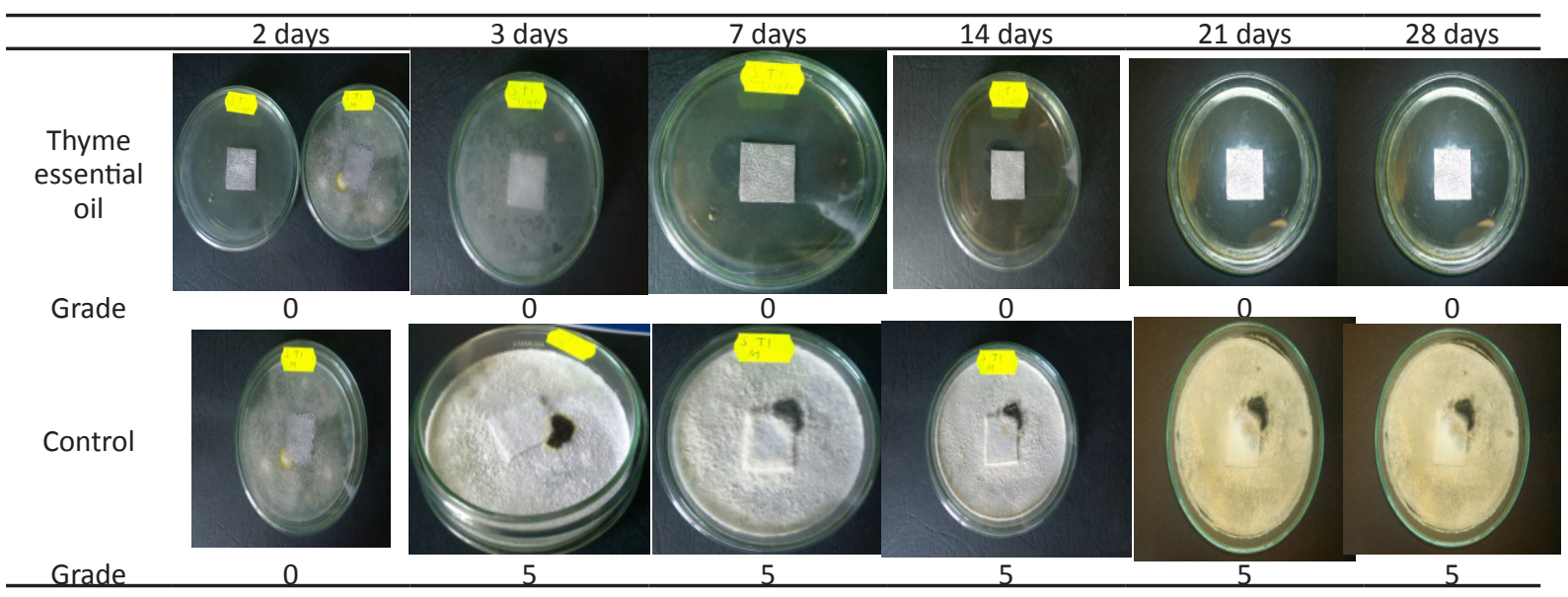

Thyme essential oil applied on sheepskin leather for lining finished with synthetic film has completely inhibited the development of the Trichophyton interdigitale species, with no increases until the end of the experiment 28 days. In the control samples, increases of pathogen were observed after 2 days; after 7 days the leather samples were completely covered by the pathogen, the synthetic film failing to protect the leather.

\section{CONCLUSION}

The results obtained in this study show that Thymus vulgaris oil exhibited high antifungal activity against Trichophyton interdigitale. Thyme oil proved to be the best inhibitor of fungi conferred by high thymol and/or carvacrol content. Thyme oil offers a much safer alternative to toxic biocides.

The results of this study may have potential for use in the development of applications in the sanitation of footwear components.

\section{Acknowledgements}

This study was financed by the Ministry of Research and Innovation in the framework of Nucleu Program INOVA-TEX-PEL, 2016-2017, contract 26/2016, project code PN 16340205.

\section{REFERENCES}

1. Ara, K., Hama, M., Akiba, S., Koike, K., Okisaka, K., Hagura, T., Kamiya, T., Tomita, F., Foot Odour Due to Microbial Metabolism and its Control, Can J Microbiol, 2006, 52, 4, 357364.

2. Sánchez-Navarro, M.M., Pérez-Limiñana, M.A., Cuesta-Garrote, N., Maestre-López, M.I., Bertazzo, M., Martínez-Sánchez, M.A., Orgilés-Barceló, C., Arán-Aís, F., Latest Developments in Antimicrobial Functional Materials for Footwear, in A. Méndez-Vilas (ed.), Microbial Pathogens and Strategies for Combating them: Science, Technology and Education, 2013, Formatex Research Center.

3. Niculescu, O., Leca, M., Moldovan, Z., Deselnicu, D.C., Research on Obtaining Products for Fragrance and Biological 
Protection on Natural Leathers and Furs, Rev Chim Bucharest, 2015, 66, 12, 1956-1959.

4. Radwan, I.A., Abed, A.H., Abeer, M.R., Ibrahim, R.A., Abdallah, A.S., Effect of Thyme, Clove and Cinnamon Essential Oils on Candida albicans and Moulds Isolated from Different Sources, American Journal of Animal and Veterinary Sciences, 2014, 9, 4, 303-314.

5. Steviæ, T., Beriæ, T., Šavikin, K., Sokoviæ, M., Goðevac, D., Dimkiæ, I., Stankoviæ, S., Antifungal Activity of Selected Essential Oils against Fungi Isolated from Medicinal Plant, Ind Crops Prod, 2014, 55, 116-122.

6. Niculescu, O., Leca, M., Moldovan, Z., Deselnicu, D.C., Obtaining and Characterizing of a Product with Antifungal Properties Based on Essential Oils and Natural Waxes for Finishing Natural Leathers, Rev Chim Bucharest, 2015, 66, 11, 1733-1736.

7. Bayramoðlu, E.E., Gülümser, G., Karaboz, I., The Investigation of Antibacterial Activities of Some Essential Oils in Wet Blue Leather, International Journal of Natural and Engineering Sciences, 2008, 2, 1, 33-36.

8. Chirila, C., Crudu, M., Deselnicu, V., Comparative Study Regarding Resistance of Wet-White and Wet-Blue Leather to the Growth of Fungi, Leather and Footwear Journal, 2014, 14, 2, 107-120.

9. Chirila, C., Crudu, M., Deselnicu, V., Study Regarding the Resistance to the Growth of Fungi of Wet-White Leather Tanned with Titanium - Aluminum, Proceedings of The 5th ICAMS 2014, 23-25 October 2014, Bucharest, 31-36.

10. Chirila, C., Deselnicu, V., Crudu, M., Study Regarding the Resistance of Wet-White Leather Organic Tanned to the Growth of Fungi, Proceedings of The 5th ICAMS 2014, 23-25 October 2014, Bucharest, 37.

11. https://medlicker.com/1088-essential-oilsfor-fungal-infections

12. Kalemba, D., Kunicka, A., Antibacterial and Antifungal Properties of Essential Oils, Curr Med Chem, 2003, 10, 10, 813-29.

13. Price, L., Price, S., Aromatherapy for Health Professionals, 2007, Elsevier Health Sciences.
14. Shemesh, A., Mayo, W.L., Australian Tea Tree Oil: A Natural Antiseptic and Fungicidal Agent, Australian Journal of Pharmacy, 1991, 72, 802-803.

15. Ramsewak, R.S., Nair, M.G., Stommel, M., Selanders, L., In vitro Antagonistic Activity of Monoterpenes and Their Mixtures Against 'Toe Nail Fungus' Pathogens, Phytother Res, 2003, 17, 376-379, https://doi.org/10.1002/ ptr.1164.

16. Braga, P.C., Alfieri, M., Culici, M., Dal Sasso, M., Inhibitory Activity of Thymol against the Formation and Viability of Candida albicans hyphae, Mycoses, 2007, 50, 502-506, https:// doi.org/10.1111/j.1439-0507.2007.01412.x.

17. Berechet, M.D., Chirila, C., Deselnicu, V., Antifungal Activity of Thyme Essential Oil on Woolen Sheepskins, Proceedings of The 6th ICAMS 2016, 203-208, 20-23 October 2016, Bucharest.

18. Chirila, C., Berechet, M.D., Deselnicu, V., Thyme Essential Oil as Natural Leather Preservative against Fungi, Proceedings of The 6th ICAMS 2016, 227-232, 20-23 October 2016, Bucharest.

19. Chirila, C., Crudu, M., Deselnicu, V., Comparative Study regarding Resistance of Wet-White and Wet-Blue Leather to the Growth of Fungi, Leather and Footwear Journal, 2014, 14, 2, 107-120, https://doi. org/10.24264/Ifj.14.2.4.

20. Chirila, C., Crudu, M., Deselnicu, V., Study regarding the Resistance to the Growth of Fungi of Wet-White Leather Tanned with Titanium-Aluminum, Proceedings of The 5th ICAMS 2014, 23-25 October 2014, Bucharest, RO, 31-36, ISSN: 2068-0783, CERTEX press.

21. Chirila, C., Deselnicu, V., Crudu, M., Study regarding the Resistance of Wet-White Leather Organic Tanned to the Growth of Fungi, Proceedings of The 5th ICAMS 2014, 23-25 October 2014, Bucharest, 37-42, RO, ISSN: 2068-0783, CERTEX press.

22. Deselnicu, D.C., Vasilescu, A.M., Purcarea, A.A., Militaru, G., Sustainable Consumption and Production in the Footwear Sector, Leather and Footwear Journal, 2014, 14, 3, 159-180. 
23. Deselnicu, V., Deselnicu, D.C., Vasilescu, A.M., Militaru, G., EU Policy for Sustainable Consumption and Production - EU Ecolebal for Footwear, Proceedings of the 5th International Conference on Advanced Materials and Systems ICAMS 2014, 23-25 October 2014, Bucharest, 641-646.

24. Deselnicu, V., Maier, S.S., Albu, L., Buruntea, N., Antimicrobial and Antifungal Leathers for Increasing the Health and the Comfort of the Individuals, CORTEP, 2007, 18-21 Oct., lasi, RO.

25. Deselnicu, V., Maier, S.S., Deselnicu, O.C., Florescu, M., Impact of Technological Changes on Increased Health and Comfort Efficiency, Proceedings of The 4th International Conference in Management of Technological
Change, Book 1, Chania, Greece, 19-20 August 2005, 87-92.

26. Berechet, M.D., Essential Oils - Their Use in Practice and Research, Doctoral Thesis, 2015, Faculty of Applied Chemistry and Materials Science, "Politehnica" University of Bucharest.

(C) 2017 by the author(s). Published by INCDTP-ICPI, Bucharest, RO. This is an open access article distributed under the terms and conditions of the Creative Commons Attribution license (http://creativecommons.org/licenses/ by/4.0/). 


\section{INSTRUCTIONS FOR AUTHORS}

Publication Ethics and Malpractice Statement

Revista de Pielarie Incaltaminte publishes peer-reviewed articles. It is necessary to agree upon. The Publication Ethics and Malpractice Statement for Revista de Pielarie Incaltaminte, based on COPE's Best Practice Guidelines for Journal Editors, clearly outlines standards of expected ethical behavior for all parties involved in the act of publishing (the author, the journal editor(s), the peer reviewer and the publisher) and is available on the journal's website,

http://www.revistapielarieincaltaminte.ro.

\section{Open Access Statement}

Revista de Pielarie Incaltaminte is a peer reviewed, open access journal. All articles published open access will be immediately and permanently free for everyone to read, download, copy and distribute, under the provisions of a Creative Commons Attribution (CC BY) which lets others distribute and copy the article, create extracts, abstracts, and other revised versions, adaptations or derivative works of or from an article (such as a translation), include in a collective work (such as an anthology), text or data mine the article, even for commercial purposes, as long as they credit the author(s), do not represent the author as endorsing their adaptation of the article, and do not modify the article in such a way as to damage the author's honor or reputation.

\section{Open Access Publication Fee}

Revista de Pielarie Incaltaminte requires article processing charges of 100 EURO per article, for accepted manuscripts, payable by the author to cover the costs associated with publication. There are no submission charges.

\section{Author Rights}

The copyright for all articles published in Revista de Pielarie Incaltaminte shall remain the property of the author(s). The copyright on the layout and final design of the articles published in Revista de Pielarie Incaltaminte belongs to INCDTP - Division: Leather and Footwear Research Institute and cannot be used in other publications.

\section{Presentation of Papers}

The scientific papers should be presented for publishing in English only. The text of the article should be clear and precise, as short as possible to make it understandable. As a rule, the paper should not exceed fifteen pages, including figures, drawings and tables. The paper should be divided into heads and chapters in a logical sequence. Manuscripts must meet high scientific and technical standards. All manuscripts must be typewritten using MS Office facilities, single spaced on white A4 standard paper ( $210 \times 297 \mathrm{~mm})$ in 11-point Times New Roman (TNR) font.

\section{Paper Format}

Title. Title (Centered, 12 pt. TNR font) should be short and informative. It should describe the contents fully but concisely without the use of abbreviations.

Authors. The complete, unabbreviated names should be given (Centered, 10 pt. TNR font), along with the affiliation (institution), city, country and email address (Centered, 9 pt. TNR font). The author to whom the correspondence should be addressed should be indicated, as well as email and full postal address.

Abstract: A short abstract in a single paragraph of no more than 200-250 words must accompany each manuscript ( $8 \mathrm{pt}$. TNR font). The abstract should briefly describe the content and results of the paper and should not contain any references.

Keywords. Authors should give 3-5 keywords.

\section{Text}

Introduction. Should include the aims of the study and results from previous notable studies.

Materials and Methods. Experimental methods should be described clearly and briefly.

Results and Discussions. This section may be separated into two parts. Unnecessary repetition should be avoided.

Conclusions. The general results of the research are discussed in this section.
Acknowledgements. Should be as short as possible.

References. Must be numbered in the paper, and listed in the order in which they appear.

Diagrams, Figures and Photographs should be constructed so as to be easy to understand and should be named "Figures"; their titles should be given below the Figure itself. The figures should be placed immediately near (after or before) the reference that is being made to them in the text. Figures should be referred to by numbers, and not by the expressions "below" or "above". The number of figures should be kept to minimum (maximum 10 figures per paper).

Tables. Should be numbered consecutively throughout the paper. Their titles must be centered at the top of the tables (12 pt. TNR font). The tables text should be $9 \mathrm{pt}$. TNR font. Their dimensions should correspond to the format of the Journal page. Tables will hold only the horizontal lines defining the row heading and the final table line. The tables should be placed immediately near (after or before) the reference that is being made to them in the text. Tables should be referred to by numbers, and not by the expressions "below" or "above". The measure units (expressed in International Measuring Systems) must be explicitly presented.

Formulas, Equations and Chemical Reactions should be numbered by Arabic numbers in round brackets, in order of appearance, and should be centered. The literal part of formulas should be in Italics. Formulas should be referred to by Arabic numbers in round brackets.

Nomenclature. Should be adequate and consistent throughout the paper, should conform as much as possible to the rules for Chemistry nomenclature. It is preferable to use the name of the substances instead of the chemical formulas in the text.

References should be numbered consecutively throughout the paper in order of citation in square brackets; the references should list recent literature also. Footnotes are not allowed. If the cited literature is in other language than English, the English translation of the title should be provided, followed by the original language in round brackets. Example: Handbook of Chemical Engineer (in Romanian), vol. 2, Technical Press, Bucharest, 1951, 87.

We strongly recommend that authors cite references using DOls where possible. DOIs are persistent links to an object/entity and can be used to cite and link to any article existing online, even if full citation information is not yet available. DOls should always be displayed as full links. Example: Onem, E., Cin, G., Alankus, A., Pehlivan, H., Mutlu, M.M., Utilization of Chestnut Shell Wastes as a Dyeing Agent for Leather Industry, Revista de Pielarie Incaltaminte (Leather and Footwear Journal), 2016, 16, 4, 257-264, https://doi.org/10.24264/Ifj.16.4.1.

Citation of Journal Articles: all authors' names (surname, name initials), abbreviated journal title, year, volume number, issue number, full page reference, e.g.: Helissey, P., Giorgi-Renault, S., Renault, J., Chem Pharm Bull, 1989, 37, 9, 2413-2425.

In case the reference is not cited in original, the author(s) should also list the original paper that has been consulted.

Citation of Books: authors' full name and name (initials), title of the book, issue number in Arabic numbers, publishing house, editors' names (if present), city where the book has been published, year of publication, the page(s) containing the text that has been cited.

Citation of Patents: all authors' names (surname, name initials), or company's name, country and patent number, date of issuance.

Paper template is available for download on the journal's website, http://www.revistapielarieincaltaminte.ro.

\section{Manuscript Submission}

Manuscripts should be submitted in electronic format by email to the following address:

\section{Dr. Viorica DESELNICU, Editor-in-chief}

INCDTP - Leather and Footwear Research Institute (ICPI)

93 Ion Minulescu St., code 030215, Bucharest, Romania

Phone: +4021-323.50.60; Fax: +4021-323.52.80.

E-mail: jlfjournal@gmail.com 

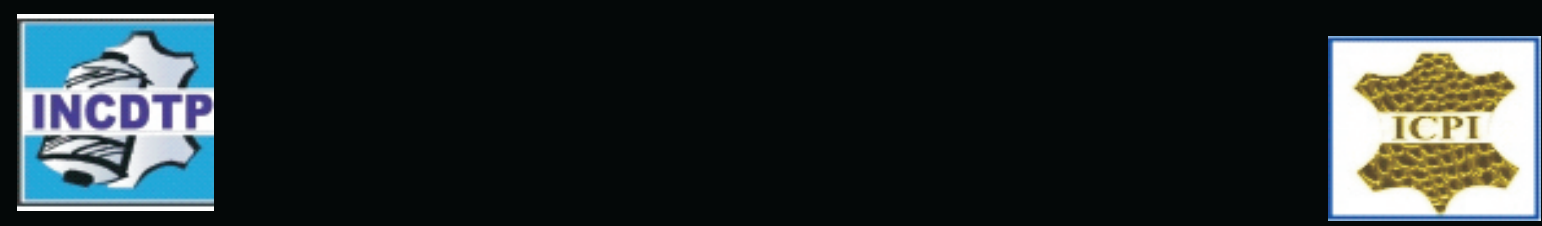

INCDTP - SUCURSALA INSTITUTUL DE CERCETĂRI PIELĂRIE ÎNCĂLȚĂMINTE

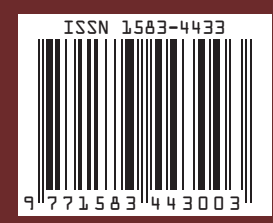

LUCRARE EDITATĂ CU SPRIJINUL MINISTERULUI CERCETĂRII ŞI INOVĂRII 